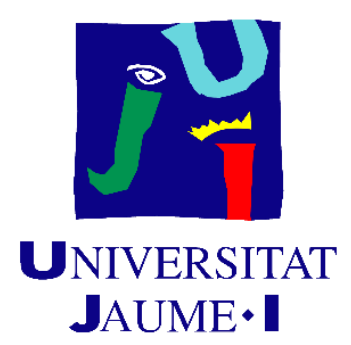

Tesis Doctoral

\title{
RELACIÓN ENTRE LA IMAGEN DE MARCA Y EL COMPORTAMIENTO DE LOS USUARIOS DE SERVICIOS DEPORTIVOS
}

Programa de Doctorado en Marketing

AUTOR:

Mario Alguacil Jiménez

DIRECTORES:

Javier Sánchez García

Ferran Calabuig Moreno

Castellón de la Plana, junio de 2020 



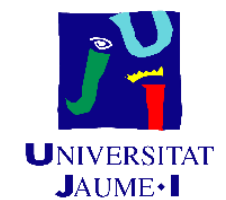

Programa de Doctorado en Marketing. Escuela de Doctorado de la Universitat Jaume I.

Título de la tesis: Relación entre la imagen de marca y el comportamiento de los usuarios de servicios deportivos.

Memoria presentada por Mario Alguacil Jiménez para optar al grado de doctor por la Universitat Jaume I.

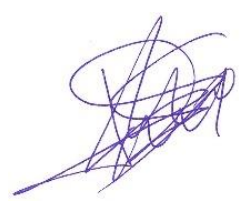

Mario Alguacil Jiménez
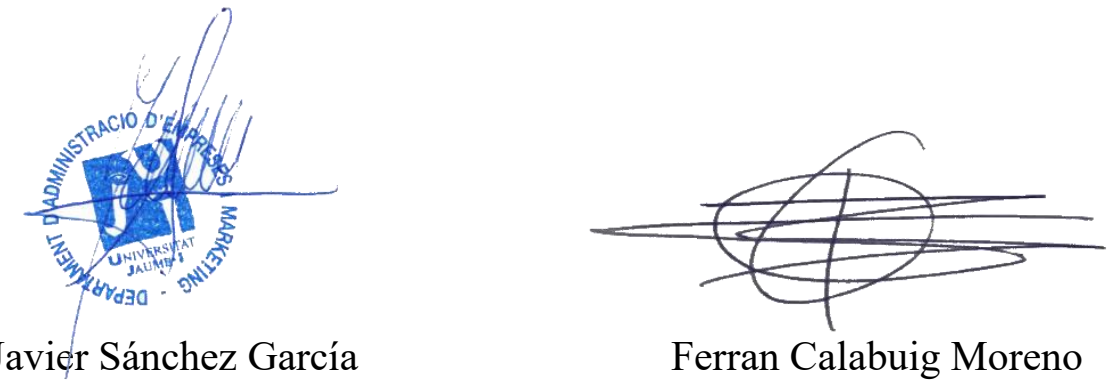

Castellón de la Plana, mayo de 2020 



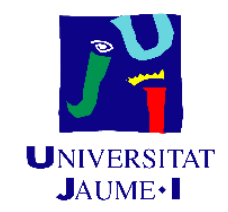

\section{AUTORIZACIÓN DE COAUTORES PARA EL USO DE LAS PUBLICACIONES}

A continuación, se muestra el documento de autorización para el uso de las publicaciones como parte de la presente tesis doctoral, firmado por cada uno de los coautores y coautoras. Con ello, se da cumplimiento al artículo 23 de la Normativa de los Estudios de Doctorado, regulados por el RD 99/2011, en la Universitat Jaume I, que fue aprobada por el Consejo de Gobierno núm. 19 de 26 de enero de 2012, modificada por el Consejo de Gobierno núm. 29 de 27 de noviembre de 2012 y con posterior modificación por el Consejo de Gobierno núm. 37 de 25 de Julio de 2013. 



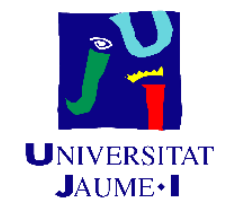

Javier Sánchez García, como coautor doy mi autorización a Mario Alguacil Jiménez para la presentación de las siguientes publicaciones como parte de su tesis doctoral.

Relación de publicaciones:

- Alguacil, M., Sánchez-García, J., \& Valantine, I. (2020). Be congruent and I will be loyal: the case of sport services. Sport in Society, 23(2), 234248.

Asimismo, renuncio a poder utilizar estas publicaciones como parte de otra tesis doctoral. Y para que conste firmo el presente documento,

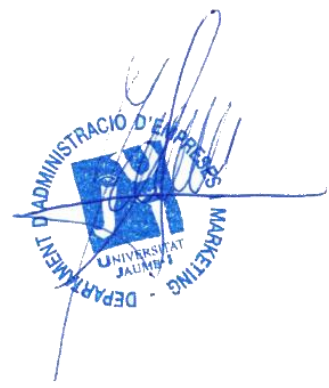

Javier Sánchez García

Castellón, a 19 de marzo de 2020 



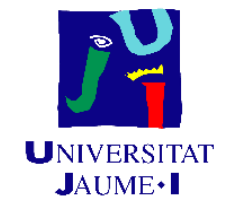

Irena Valantine, como coautora doy mi autorización a Mario Alguacil Jiménez para la presentación de las siguientes publicaciones como parte de su tesis doctoral.

Relación de publicaciones:

- Alguacil, M., Sánchez-García, J., \& Valantine, I. (2020). Be congruent and I will be loyal: the case of sport services. Sport in Society, 23(2), 234248.

- Alguacil, M., Núñez-Pomar, J.M., Valantine, I., Crespo-Hervás, J., PérezCampos, C., \& Staskeviciuté-Butiene, I. (2018). The importance of the services brand in predicting loyalty and word of mouth. Engineering Economics, 29(4), 446-454.

Asimismo, renuncio a poder utilizar estas publicaciones como parte de otra tesis doctoral. Y para que conste firmo el presente documento,

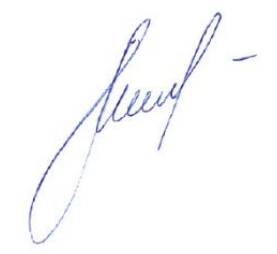

Irena Valantine

Kaunas, a 12 de marzo de 2020 



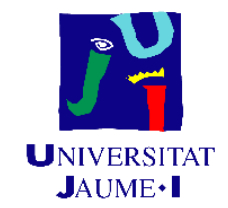

Inga Staskeviciuté-Butiene, como coautora doy mi autorización a Mario Alguacil Jiménez para la presentación de las siguientes publicaciones como parte de su tesis doctoral.

Relación de publicaciones:

- Alguacil, M., Núñez-Pomar, J.M., Valantine, I., Crespo-Hervás, J., PérezCampos, C., \& Staskeviciuté-Butiene, I. (2018). The importance of the services brand in predicting loyalty and word of mouth. Engineering Economics, 29(4), 446-454.

Asimismo, renuncio a poder utilizar estas publicaciones como parte de otra tesis doctoral. Y para que conste firmo el presente documento,

Inga Staskeviciuté-Butiene

Kaunas, a 12 de marzo de 2020 



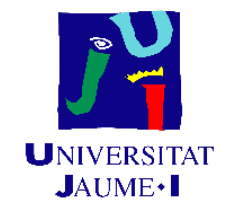

Juan Manuel Núñez-Pomar, como coautor doy mi autorización a Mario Alguacil Jiménez para la presentación de las siguientes publicaciones como parte de su tesis doctoral.

Relación de publicaciones:

- Alguacil, M., Núñez-Pomar, J.M., Valantine, I., Crespo-Hervás, J., PérezCampos, C., \& Staskeviciuté-Butiene, I. (2018). The importance of the services brand in predicting loyalty and word of mouth. Engineering Economics, 29(4), 446-454.

- Alguacil, M., Núñez-Pomar, J., Pérez-Campos, C., \& Prado-Gascó, V. (2019). Perceived value, satisfaction and future intentions in sport services: putting congruence and brand trust in the equation. Linear Models vs QCA. Academia Revista Latinoamericana de Administración, 32(4), 566-579.

Asimismo, renuncio a poder utilizar estas publicaciones como parte de otra tesis doctoral. Y para que conste firmo el presente documento,

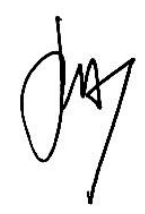

Juan Manuel Núñez Pomar

Valencia, a 16 de marzo de 2020 



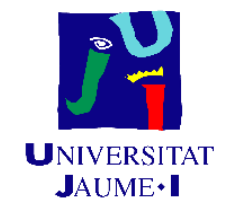

Carlos Pérez-Campos, como coautor doy mi autorización a Mario Alguacil Jiménez para la presentación de las siguientes publicaciones como parte de su tesis doctoral.

Relación de publicaciones:

- Alguacil, M., Núñez-Pomar, J.M., Valantine, I., Crespo-Hervás, J., PérezCampos, C., \& Staskeviciuté-Butiene, I. (2018). The importance of the services brand in predicting loyalty and word of mouth. Engineering Economics, 29(4), 446-454.

- Alguacil, M., Núñez-Pomar, J., Pérez-Campos, C., \& Prado-Gascó, V. (2019). Perceived value, satisfaction and future intentions in sport services: putting congruence and brand trust in the equation. Linear Models vs QCA. Academia Revista Latinoamericana de Administración, 32(4), 566-579.

Asimismo, renuncio a poder utilizar estas publicaciones como parte de otra tesis doctoral. Y para que conste firmo el presente documento.

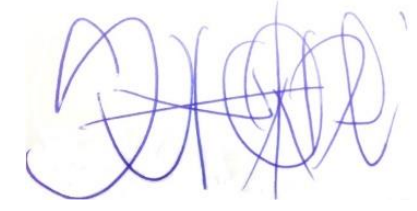

Carlos Pérez Campos

Valencia, a 16 de marzo de 2020 



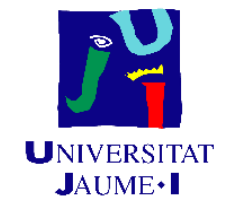

Josep Crespo-Hervás, como coautor doy mi autorización a Mario Alguacil Jiménez para la presentación de las siguientes publicaciones como parte de su tesis doctoral.

Relación de publicaciones:

- Alguacil, M., Núñez-Pomar, J.M., Valantine, I., Crespo-Hervás, J., PérezCampos, C., \& Staskeviciuté-Butiene, I. (2018). The importance of the services brand in predicting loyalty and word of mouth. Engineering Economics, 29(4), 446-454.

Asimismo, renuncio a poder utilizar estas publicaciones como parte de otra tesis doctoral. Y para que conste firmo el presente documento,

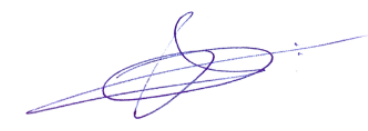

Josep Crespo Hervás

Valencia, a 16 de marzo de 2020 



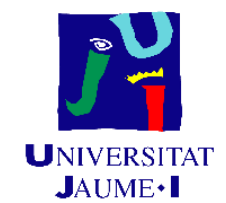

Vicente Javier Prado Gascó, como coautor doy mi autorización a Mario Alguacil Jiménez para la presentación de las siguientes publicaciones como parte de su tesis doctoral.

Relación de publicaciones:

- Alguacil, M., Núñez-Pomar, J., Pérez-Campos, C., \& Prado-Gascó, V. (2019). Perceived value, satisfaction and future intentions in sport services: putting congruence and brand trust in the equation. Linear Models vs QCA. Academia Revista Latinoamericana de Administración, 32(4), 566-579.

Asimismo, renuncio a poder utilizar estas publicaciones como parte de otra tesis doctoral. Y para que conste firmo el presente documento,

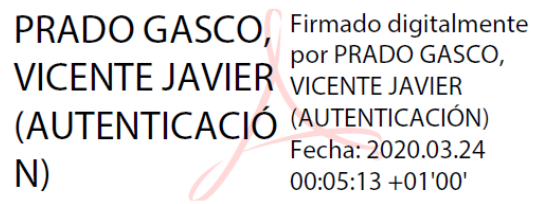

Vicente Javier Prado Gascó

Valencia, a 24 de marzo de 2020 

Aurea Mediocritas 



\section{AGRADECIMIENTOS}

Son muchos los que de una u otra manera han apoyado para que esta tesis pueda llevarse a cabo. En primer lugar, me gustaría dar las gracias a mis tutores Javier Sánchez y Ferran Calabuig, por darme la oportunidad y por su ayuda. También a toda la familia del grupo de investigación en gestión deportiva de la Universidad de Valencia, por hacer más provechosa y mucho más llevadera esta carrera académica e investigadora que compartimos, así como al resto de compañeros de grupos de investigación del ámbito con los que tenemos la suerte de colaborar.

A mis amigos de toda la vida y a los que vinieron más tarde. En muchas ocasiones no son conscientes de lo importantes que son y de lo que ayudan con los ratos que compartimos.

Finalmente, a mi pareja y familia. Todo lo que pueda decir sería poco para lo que tengo que agradecerles. A mi pareja por apoyar sin medida, incluso cuando eso supone verse perjudicada, te debo mucho. A mi familia por dármelo todo y estar siempre ahí, por animar a la formación y por enseñarnos el valor del esfuerzo y la constancia, grabando a fuego lo de que "El que algo quiere, algo le cuesta". 



\section{ÍNDICES}





\section{ÍNDICE DE CONTENIDOS}

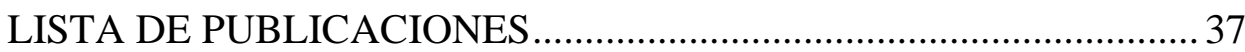

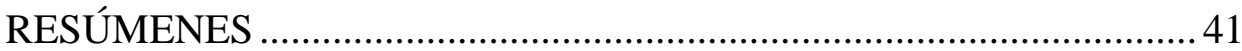

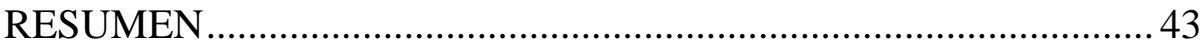

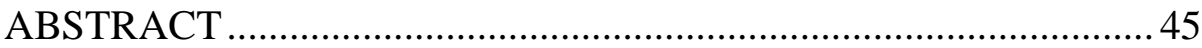

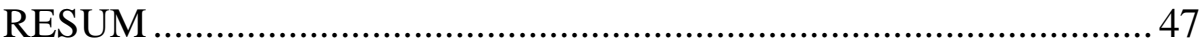

CAPÍTULO I. INTRODUCCIÓN Y APORTACIÓN DE LA TESIS .... 49

1. INTRODUCCIÓN Y APORTACIÓN DE LA TESIS .....................51

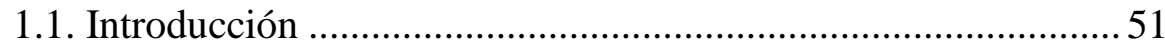

1.2. Aportación original del autor .....................................................52

CAPITULO II. MARCO TEÓRICO ….............................................. 55

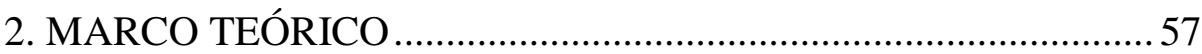

2.1. Los servicios y el marketing.................................................. 57

2.2. Identidad de marca e imagen de marca ....................................58

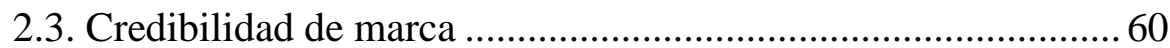

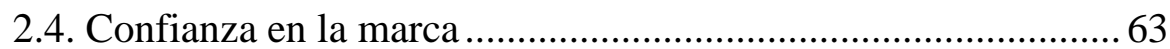

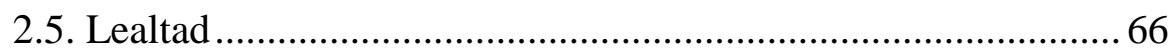

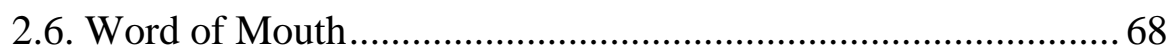

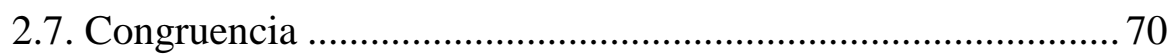

2.8. Actitudes hacia la marca …................................................... 72 
Índice de contenidos

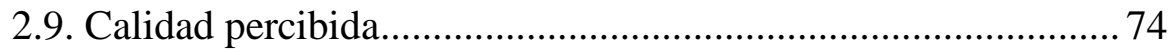

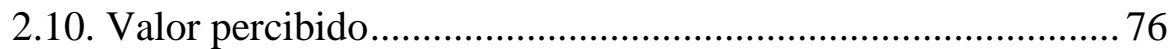

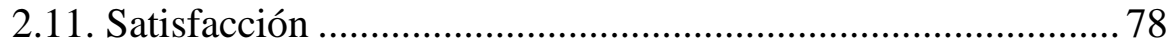

CAPÍTULO III. OBJETIVOS E HIPÓTESIS DE LOS ESTUDIOS .......81

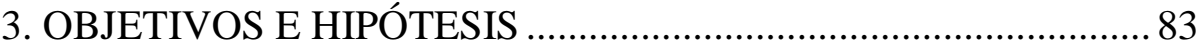

3.1. Objetivo general de la tesis y objetivos de los estudios ............ 83

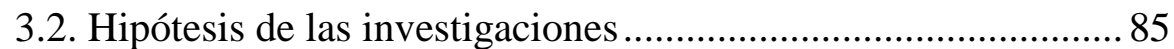

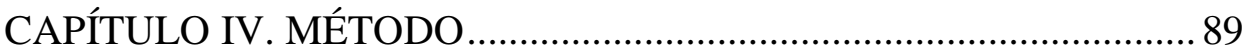

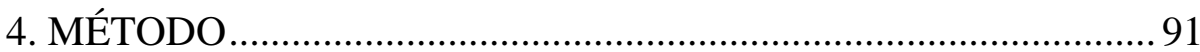

4.1. Población objeto de estudio y muestras de participantes .......... 91

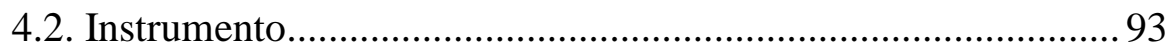

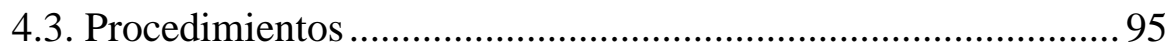

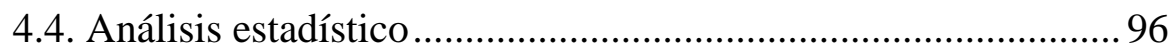

4.4.1. Estudio 1. The importance of the services brand in predicting loyalty and word of mouth .......................................................... 97

4.4.2. Estudio 2. Perceived value, satisfaction and future intentions in sport services: putting congruence and brand trust in the equation. Linear models vs QCA .............................................. 98

4.4.3. Estudio 3. Be congruent and I will be loyal: the case of sport

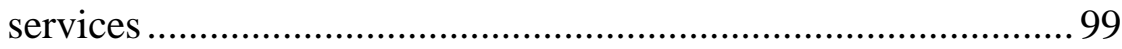

CAPÍTULO V. RESULTADOS Y DISCUSIÓN ................................... 101 
Índice de contenidos

5. RESULTADOS Y DISCUSIÓN.... 103

5.1. Resultados 103

5.1.1. Estudio 1. The importance of the services brand in predicting loyalty and word of mouth 105

5.1.2. Estudio 2. Perceived value, satisfaction and future intentions in sport services: putting congruence and brand trust in the equation. Linear models vs QCA 117

5.1.3. Estudio 3. Be congruent and I will be loyal: the case of sport services 133

5.2. Resumen de los resultados 151

5.2.1. Estudio 1. The importance of the services brand in predicting loyalty and word of mouth 153

5.2.2. Estudio 2. Perceived value, satisfaction and future intentions in sport services: putting congruence and brand trust in the equation. Linear models vs QCA 157

5.2.3. Estudio 3. Be congruent and I will be loyal: the case of sport services 165

5.3. Discusión 171

CAPÍTULO VI. CONCLUSIONES 177

6. CONCLUSIONES 179

6.1. Estudio 1. The importance of the services brand in predicting loyalty and word of mouth 179 
Índice de contenidos

6.2. Estudio 2. Perceived value, satisfaction and future intentions in sport services: putting congruence and brand trust in the equation. Linear models vs QCA 180

6.3. Estudio 3. Be congruent and I will be loyal: the case of sport services

182

Capítulo VII. IMPLICACIONES, LIMITACIONES Y LÍNEAS FUTURAS DE INVESTIGACIÓN ...................................................... 183

7. IMPLICACIONES, LIMITACIONES Y LÍNEAS FUTURAS DE

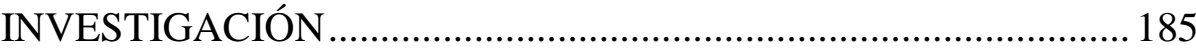

7.1. Implicaciones para el marketing y la gestión deportiva .......... 185

7.2. Limitaciones y líneas futuras de investigación ........................ 186

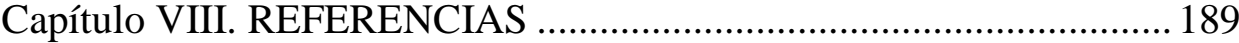

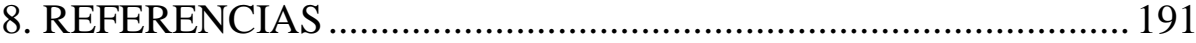

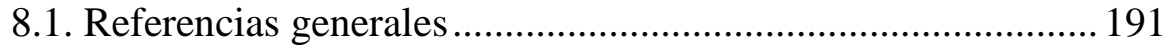

8.2. Referencias Estudio 1. The importance of the services brand in predicting loyalty and word of mouth 205

8.3. Referencias Estudio 2. Perceived value, satisfaction and future intentions in sport services: putting congruence and brand trust in the equation. Linear models vs QCA ….............................................215

8.4. Referencias Estudio 3. Be congruent and I will be loyal: the case

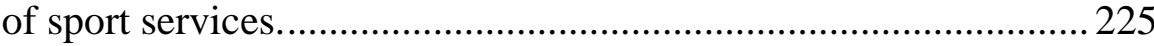

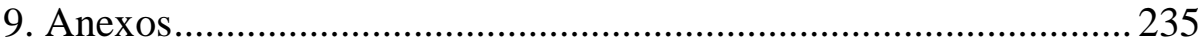


Índice de contenidos

9.1. Anexo I. Código QR del archivo PDF del estudio 1 ............... 235

9.2. Anexo II. Código QR del archivo PDF del estudio 2 ............ 237

9.3. Anexo III. Código QR del archivo PDF del estudio 3 ............239 



\section{ÍNDICE DE TABLAS}

Tabla 1. Resumen de las hipótesis del estudio 1 ...................................86

Tabla 2. Resumen de las hipótesis del estudio 2 ................................. 87

Tabla 3. Resumen de las hipótesis del estudio 3 ............................... 87

Tabla 4. Validez convergente del instrumento del estudio 1 .................. 155

Tabla 5. Resultados de las hipótesis del estudio 1 .............................. 156

Tabla 6. Modelo de regresión jerárquica del estudio 2 .......................... 160

Tabla 7. Análisis de necesidad del estudio 2........................................ 161

Tabla 8. Análisis de suficiencia del estudio 2 .................................... 163

Tabla 9. Resultados de las hipótesis del estudio 2 ............................... 164

Tabla 10. Indicadores de validez convergente en el estudio 3 ............... 168

Tabla 11. Validez discriminante en el estudio 3 .................................. 168

Tabla 12. Resultados de las hipótesis del estudio 3 ............................. 170 

Índice de figuras

\section{ÍNDICE DE FIGURAS}

Figura 1. Hipótesis del modelo estructural del estudio 1 ...................... 156

Figura 2. Modelo estructural del estudio 3....................................... 167

Figura 3. Modelo de relaciones causales del estudio 3 ........................ 169 



\section{LISTA DE PUBLICACIONES}



La presente tesis doctoral se ha realizado mediante un compendio de artículos científicos, cumpliendo con los criterios del Programa de Doctorado en Marketing de la Universitat Jaume I de Castellón que indican que, dichos artículos, deben estar publicados en revistas recogidas en el Journal Citation Reports (JCR) de la Web of Knowledge (WOK). A continuación, se presentan las referencias, así como el factor de impacto asociado a las revistas en las que se han publicado:

1. Alguacil, M., Núñez-Pomar, J.M., Valantine, I., Crespo-Hervás, J., Pérez-Campos, C., \& Staskeviciuté-Butiene, I. (2018). The importance of the services brand in predicting loyalty and word of mouth. Engineering Economics, 29(4), 446-454. Factor Impacto 2018: (JCR= 0.730; Q4) (SJR= $0.288 ; \mathrm{Q} 2)$.

2. Alguacil, M., Núñez-Pomar, J., Pérez-Campos, C., \& Prado-Gascó, V. (2019). Perceived value, satisfaction and future intentions in sport services: putting congruence and brand trust in the equation. Linear Models vs QCA. Academia Revista Latinoamericana de Administración, 32(4), 566-579. Factor impacto: 2018 (JCR= 0.474; Q4) (SJR= 0.199; Q3).

3. Alguacil, M., Sánchez-García, J., \& Valantine, I. (2020). Be congruent and I will be loyal: the case of sport services. Sport in Society, 23(2), 234248. Factor impacto $2018(\mathrm{JCR}=0.768 ; \mathrm{Q} 4)(\mathrm{SJR}=.548 ; \mathrm{Q} 1)$.

Esta tesis dispone de la aceptación por parte de los coautores para que las publicaciones formen parte del compendio, así como de su renuncia expresa a presentarlas como parte de otra tesis doctoral. 



\section{RESÚMENES}





\section{RESUMEN}

En la presente tesis doctoral se han llevado a cabo tres estudios relacionados con la percepción de marca, orientados a su análisis en el ámbito de los servicios deportivos. La percepción de marca es un elemento de interés, debido a las influencias que tiene el cómo percibimos las marcas en nuestros comportamientos como consumidores, pero el análisis de estos aspectos es prácticamente inexistente en el ámbito de los servicios deportivos. Si conocemos cómo se percibe una marca y qué relación tiene con el comportamiento del consumidor, no solo podremos conocer mejor las necesidades que pueden tener los usuarios, sino que también podremos predecir sus conductas como consumidores, lo que permitirá crear estrategias más concretas para cada perfil de usuario, de forma que sean más efectivas y requieran un menor gasto de recursos.

En el estudio 1 se pretende comprobar cuál es la influencia que tiene la calidad percibida de la marca de un servicio sobre la credibilidad que perciben los usuarios de ella y las actitudes que estos generan hacia dicha marca, para posteriormente conocer si existe una influencia significativa de las variables anteriormente comentadas sobre los niveles de lealtad y recomendación y, de ser así, en qué medida lo son.

En el estudio 2, el objetivo es introducir la confianza y la congruencia en el modelo clásico de servicio formado por las variables de calidad, valor y satisfacción, para comprobar mediante modelos de regresión jerárquica (HRM), si la capacidad predictiva de los modelos que tratan de explicar el 
valor percibido, la satisfacción y las intenciones futuras, mejora significativamente con la inclusión de dichas variables, en comparación con el modelo clásico. Posteriormente se realiza un análisis cualitativo comparativo (QCA) para conocer si existen variables necesarias para llegar al resultado esperado y cuáles son las interacciones suficientes que más permitan explicar dichos resultados de interés.

En el estudio 3, se plantea un modelo de ecuaciones estructurales mediante modelado de ecuaciones estructurales (SEM), en el que se parte de la congruencia del usuario con la marca, para testar si esa congruencia genera mayores niveles de credibilidad y de confianza, así como si estas variables influyen significativamente en la creación de una mejor disposición hacia la marca. Finalmente, se comprueba si las actitudes hacia la marca son predictoras de la lealtad que tendrán los usuarios hacia ella.

Las principales conclusiones que se extraen de los diferentes estudios, tienen que ver con la importancia de las variables de marca para la explicación de las percepciones de rendimiento del servicio deportivo, y cómo de esa combinación de ambas, se pueden extraer porcentajes altos de la explicación del comportamiento de los consumidores, en relación a aspectos como la lealtad y la recomendación, que son fundamentales para el funcionamiento y sostenibilidad de cualquier empresa. 


\section{ABSTRACT}

In this doctoral thesis 3 studies have been carried out related to brand perception in the field of sports services. Brand perception is an element of interest due to the influences of how we perceive brands in our behaviour as consumers, but the analysis of these aspects is practically non-existent in the field of sports services. If we know how a brand is perceived and how it relates to consumer behaviour, not only will we be able to better understand the needs that users may have, but we will also be able to predict their behaviour as consumers, which allows us to create more specific strategies for each user profile so that they are more effective and require less expenditure of resources.

In Study 1 the aim of study 1 is to test the influence that the perceived quality of a service brand has on the credibility that users perceive of it and the attitudes that they generate towards that brand. The study will then determine whether the previously mentioned variables have a significant influence on loyalty and recommendation levels and, if so, to what extent.

Study 2 seeks to introduce trust and congruence into the classical service model formed by the variables of quality, value and satisfaction, in order to check through hierarchical regression models (HRM), whether the predictive capacity of the models that try to explain the perceived value, satisfaction and future intentions, improves significantly with the inclusion of these variables, compared to the classical model. A comparative qualitative analysis (QCA) is then carried out to find out if there are 
variables needed to reach the expected result and which are sufficient interactions to best explain these results of interest.

In study 3 a structural equation model is proposed by means of structural equation modelling (SEM), in which the starting point is user congruence with the brand, to test whether this congruence generates higher levels of credibility and trust, as well as whether these variables significantly influence the creation of a better disposition towards the brand. Finally, it is tested whether attitudes towards the brand are predictive of the loyalty that users will have towards it.

The main conclusions drawn from the different studies are related to the importance of brand variables in explaining perceptions of sports service performance, and how from that combination, high percentages can be extracted from the explanation of consumer behaviour, in terms of aspects such as loyalty and recommendation, which are fundamental for the functioning and sustainability of any company. 


\section{RESUM}

En la present tesi doctoral s'han dut a terme tres estudis relacionats amb la percepció de marca, orientats al seu anàlisi en l'àmbit dels serveis esportius. La percepció de marca és un element d'interés, a causa de les influències que té el com percebem les marques en els nostres comportaments com a consumidors, però l'anàlisi d'aquests aspectes és pràcticament inexistent en l'àmbit dels serveis esportius. Si coneixem com es percep una marca i quina relació té amb el comportament del consumidor, no sols podrem conèixer millor les necessitats que poden tindre els usuaris, sinó que també podrem predir les seues conductes com a consumidors, la qual cosa permetrà crear estratègies més concretes per a cada perfil d'usuari, de manera que siguen més efectives i requerisquen d'una menor despesa de recursos.

En l'estudi 1 es pretén comprovar quina és la influència que té la qualitat percebuda de la marca d'un servei sobre la credibilitat que perceben els usuaris d'ella $\mathrm{i}$ les actituds que aquests generen cap a aquesta marca, per a posteriorment conèixer si existeix una influència significativa de les variables anteriorment comentades sobre els nivells de lleialtat i recomanació i, en aquest cas, en quina mesura ho són.

En l'estudi 2, l'objectiu és introduir la confiança i la congruència en el model clàssic de servei format per les variables de qualitat, valor i satisfacció, per a comprovar mitjançant models de regressió jeràrquica (HRM), si la capacitat predictiva dels models que tracten d'explicar el valor percebut, la satisfacció i les intencions futures, millora significativament 
amb la inclusió d'aquestes variables, en comparació amb el model clàssic. Posteriorment es realitza un anàlisi qualitatiu comparatiu (QCA) per a conèixer si existeixen variables necessàries per a arribar al resultat esperat i quines són les interaccions suficients que més permeten explicar aquests resultats d'interés.

En l'estudi 3, es planteja un model de relacions causals mitjançant modelatge d'equacions estructurals (SEM), en el qual es parteix de la congruència de l'usuari amb la marca, per a testar si aquesta congruència genera majors nivells de credibilitat i de confiança, així com si aquestes variables influeixen significativament en la creació d'una millor disposició cap a la marca. Finalment, es comprova si les actituds cap a la marca són predictores de la lleialtat que tindran els usuaris cap a ella.

Les principals conclusions que s'extrauen dels diferents estudis, tenen a veure amb la importància de les variables de marca per a l'explicació de les percepcions de rendiment del servei esportiu, i com de la combinació d'ambdues, es poden extraure percentatges alts de l'explicació del comportament dels consumidors, en relació a aspectes com la lleialtat i la recomanació, que són fonamentals per al funcionament i sostenibilitat de qualsevol empresa. 


\section{CAPÍTULO I. INTRODUCCIÓN Y APORTACIÓN DE LA TESIS}





\section{INTRODUCCIÓN Y APORTACIÓN DE LA TESIS}

\subsection{Introducción}

La gestión deportiva es un área relativamente joven dentro del ámbito científico, pero a pesar de ello, ha sufrido un crecimiento muy rápido en poco tiempo (Pitts, 2001), unido al enorme desarrollo que ha mostrado el contexto deportivo, que sigue creciendo a buen ritmo. Dentro de la gestión deportiva, encontramos numerosas líneas de investigación, como el papel del social media en la gestión deportiva (López-Carril, Villamón, \& Añó, 2019), el clima organizacional (Escamilla-Fajardo, Núñez-Pomar, PradoGascó, \& Ratten, 2020) y el emprendimiento (González-Serrano et al., 2018; Ratten \& Tajeddini, 2019), pasando por el análisis del impacto de los eventos y el turismo deportivo (González-García et al., 2018; ParraCamacho et al., 2012), el patrocinio deportivo (Alonso-Dos Santos, Calabuig, \& Franco, 2019) o, como es el caso de esta tesis doctoral, la imagen de marca y su relación con el rendimiento percibido en servicios deportivos (Alguacil, Crespo-Hervás, \& Pérez-Campos, 2020; CrespoHervás, Alguacil, \& Núñez-Pomar, 2018). Leyendo estas líneas, podría pensarse que un área de investigación como la imagen de marca, que está relacionada con un área tan trabajada como es el marketing, tiene poco que aportar al ámbito académico, a tenor de las numerosas publicaciones que existen sobre muchos aspectos del marketing, pero esto no es realmente así. Tal y como defendía Chalip (2006), para que la gestión deportiva siga 
creciendo y tenga la importancia que merece, se debe hacer ver que el análisis del contexto deportivo, por las propias características del deporte, tiene unas peculiaridades que lo diferencian del resto de contextos. Por tanto, a pesar de que obviamente las herramientas y estrategias del marketing general pueden adaptarse al contexto deportivo, y suponen la base que permite su análisis, tiene interés analizar en profundidad esta área, con sus características diferenciales. Este análisis puede arrojar resultados diferentes a lo ya conocido en otros ámbitos y, por tanto, aportar información concreta sobre el contexto deportivo, que resulta valiosa para los gestores deportivos y gestores de marketing, ayudándoles a comprender en mayor medida el comportamiento del consumidor deportivo y haciendo que puedan tomar mejores decisiones con un menor gasto de recursos.

\subsection{Aportación original del autor}

El análisis de la imagen de marca en servicios deportivos ofrece una nueva línea de investigación, que ha sido poco desarrollada hasta la fecha pero que está reflejando un interés creciente por parte de los gestores, así como por parte de los académicos que quieren dar respuesta a esas inquietudes provenientes de la realidad empresarial. Conocer los aspectos que rodean a la imagen de marca, tiene distintas implicaciones. Por un lado, dada la falta de información, permite conocer las diferentes relaciones que se establecen entre las variables de la marca, comprobando si muestran una influencia significativa entre ellas y en qué medida lo hacen, es decir, permite conocer el funcionamiento de las distintas variables en ese nuevo contexto. Por otro lado, también permite comprobar de qué manera dichas variables de marca 
ayudan a predecir aspectos relacionados con el rendimiento del servicio, como la calidad percibida, el valor y la satisfacción. A partir de la combinación de las variables de marca y rendimiento, podremos entender en mayor medida el comportamiento de los consumidores, atendiendo a variables como la lealtad y la recomendación. Por tanto, se aporta información útil para que, partiendo de la imagen de marca que perciben los usuarios, los gestores puedan conocer cómo se percibe dicha marca, qué fortalezas y debilidades tiene, y así poder establecer pautas que sirvan para orientar la marca de forma más acertada, atendiendo a aquellos aspectos que han mostrado ser influyentes para que el consumidor perciba un mayor rendimiento del servicio y para que su comportamiento sea el deseado. Esto redunda en un doble beneficio, ya que permite a los gestores tener herramientas para que las estrategias de marketing y prestación del servicio sean más efectivas y eficientes y, al mismo tiempo, que los consumidores reciban un mejor servicio, más adaptado a sus necesidades. 

CAPITULO II. MARCO TEÓRICO 



\section{MARCO TEÓRICO}

\subsection{Los servicios y el marketing}

Cuando hablamos de servicios, entendemos que estos servicios tienen el objetivo de satisfacer una necesidad que se manifiesta a través de una demanda, ya sea en el ámbito público o privado. En este sentido, Grönroos (1994) define que un servicio corresponde a una actividad en la que se producen interacciones entre empleados y clientes y que posee una naturaleza intangible en mayor o menor grado. Esta intangibilidad representa el aspecto más característico de los servicios, además de otras peculiaridades como el carácter perecedero, ya que los servicios no se pueden almacenar, la heterogeneidad que hace que cada servicio sea diferente, a diferencia de los bienes tangibles, y la inseparabilidad, ya que el servicio se produce y se consume en un mismo espacio temporal (Zeithaml, Parasuraman, \& Berry, 1985). Respecto al marketing que se lleva a cabo en los servicios, lógicamente las peculiaridades comentadas previamente, marcarán las acciones que se vayan a llevar a cabo. En este sentido, hemos encontrado aportaciones que defendían que el marketing debía ser el mismo para bienes y para servicios en cuanto a las acciones de marketing que se realizaban (Enis \& Roering, 1981) mientras que otros sostenían que el marketing utilizado no debe ser diferente, pero que, a pesar de ello, dado que sabemos que los servicios tienen características diferenciales respecto a los bienes, debemos tenerlas en cuenta (Berry, 1980). La aportación de Lamb (1987) marcó un paso importante para que 
el marketing de servicios sufriera un proceso de especialización, ya que mostró que la insatisfacción creciente de los usuarios, así como el aumento de la competencia, requerían de un marketing especializado para los servicios que diera respuesta a esos desafíos que se estaban produciendo.

\subsection{Identidad de marca e imagen de marca}

Las investigaciones acerca de la identidad de marca y la imagen de marca son un elemento que ha ido creciendo en los últimos años, encontrando cada vez más publicaciones en este sentido (Barnes \& Higgins, 2020; Chen et al., 2020; Errajaa, Daucé, \& Legoherel, 2020; Essamri, McKechnie, \& Winklhofer, 2019; Favier, Celhay, \& Pantin-Sohier, 2019; Greyser, \& Urde, 2019; Iglesias et al., 2019). En la gestión de una marca, encontramos a nivel general dos conceptos que resultan claves para entender el proceso de creación y gestión de una marca: la identidad de marca y la imagen de marca. En este sentido, Sääksjärvi y Samiee (2011) indican que la identidad es cómo aspira a ser percibida la marca, mientras que la imagen de marca es lo que los usuarios perciben de ella. Por tanto, la identidad está relacionada con la estrategia que plantea la empresa acerca de cómo quiere ser, cómo quiere que sea su marca y qué aspectos pretende desarrollar a través de ella para intentar que los usuarios la perciban de una determinada forma. Sin embargo, aunque el trabajo de la identidad de marca tiene una importancia innegable, lo realmente definitivo es cómo los usuarios perciben esa marca, es decir, su imagen de marca, porque el cómo ellos la perciban será lo que influirá en el cómo actuarán respecto a ella (Burmann, Schaefer, \& Maloney, 2008). La percepción de la marca no solo tendrá que 
ver con el producto, ya que la marca engloba muchas más cosas. Así, encontramos por ejemplo estudios recientes que analizan la imagen del CEO de la marca (Halford \& Hsu, 2014; Njoroge \& Obonyo, 2017; Re \& Rule, 2016) entendiendo que la imagen percibida de ese CEO puede ser influyente al igual que otros aspectos percibidos de la marca, por lo que tratan de comparar las posibles diferencias entre la imagen de marca y la imagen percibida del CEO (Hafiz \& Ali, 2018).

A nivel conceptual, la imagen de marca se entiende como el conjunto de significados que hacen que una marca sea conocida y a través de los cuáles los usuarios pueden describirla, recordarla y relacionarla (Dowling, 1986). Por tanto, los usuarios elaboran una estructura mental en relación a las marcas, agrupando un conjunto de atributos que les sirven para identificarlas y para ser punto de partida de sus opiniones sobre ellas. Ese conjunto de significados se resume en las impresiones que tienen los usuarios sobre una marca, y ese resumen les permite simplificar el proceso de toma de decisiones (Aaker, 1996). Parece lógico pensar que aquellas marcas más reconocidas o que resultan más llamativas sean aquellas que pueden hacer que la gente se relacione con ella o que se sienta definido por ella, pero también se ha demostrado que esto ocurre con otras marcas mucho más comunes (Gaustad et al., 2019). Lógicamente, un proceso subjetivo como este, conlleva una gran dificultad, ya que cada persona percibe de manera distinta y prioriza ciertos aspectos sobre otros, lo que hace que el trabajo de la marca sea mucho más complejo de lo que a priori pudiera parecer. Además, en el proceso de toma de decisiones anteriormente comentado, no solo entran en juego procesamientos de 
información racionales, sino también irracionales, donde los aspectos emocionales tienen un papel importante (Dobni \& Zinkhan, 1990). Debido a ello, existen estudios que pretenden conocer en mayor profundidad cuál es la relación que se genera entre las marcas y las emociones de los consumidores (Tellis et al., 2019; Xie, Bagozzi, \& Grønhaug, 2019). Si a pesar de las dificultades que estamos comentando, la compañía consigue crear y transmitir adecuadamente su imagen de marca, y consigue además que esta se mantenga en niveles positivos a lo largo del tiempo, consolidará esa imagen de marca, creando lo que conocemos como reputación (Johnson et al., 2019; Loureiro, Sarmento, \& Le-Bellego, 2017). El rendimiento y dicha reputación, se formarán a partir de elementos como el logo, el nombre, la marca en general, así como la conciencia de los usuarios sobre ella (Foroudi, 2019) y supondrá un elemento diferencial en la alta competencia entre marcas que hay en el mercado, mejorando el valor de los productos que ofrece la marca y los resultados económicos de la empresa (Villafañe, 2001).

\subsection{Credibilidad de marca}

El concepto de credibilidad de marca tiene sus raíces ya en los años 50, donde estudios como el de Hovland, Janis y Kelley (1953) hablan de la credibilidad de marca como una fuente de habilidad percibida y motivación orientada a transmitir una información precisa a los consumidores. Este concepto puede relacionarse con la teoría de la identidad social de Abrams y Hogg (1988), ya que dicha teoría permite entender cómo la credibilidad que una marca transmite a su público objetivo, puede influenciarles en sus 
comportamientos. La teoría de la identidad social explica que los consumidores, a través de procesos de categorización, se clasifican así mismos en una categoría social, enfatizando las similitudes que tienen con otros miembros de otros grupos, creando así su identidad personal (An et al., 2019). Una vez que se ha creado su identidad personal, protegen el interés del grupo, intentando construir y mantener una autoimagen y una autoestima que sea consistente (Tajfel \& Turner, 1979), esto ocurre también con las marcas, ya que los usuarios conectan con ellas y crean sus grupos sociales, manteniendo, promoviendo y protegiendo sus conexiones y utilizando, por ejemplo, la recomendación (An et al., 2019). En este sentido encontramos dos aspectos que son muy importantes, por un lado, la auto conexión con la marca, que tiene que ver con el grado en que los usuarios han incorporado la marca a su auto concepto (Escalas \& Bettman, 2003) y, por otro lado, la conexión social, que hace referencia al grado en que los consumidores desarrollan el sentimiento de estar conectados con otros usuarios de marcas (Lobschat et al., 2013).

Por otro lado, la credibilidad también ha sido relacionada con la teoría de señales (Spence, 1973) que argumenta que, en los procesos de transmisión de la información, existe un emisor que trata de transmitir información creíble hacia un receptor, eligiendo el cómo pretende hacerlo, de la misma forma que el receptor elegirá cómo interpretar dicha información (Conelly et al., 2011) con la intención de que esa credibilidad les haga percibir al emisor o agente como un elemento fiable. Lógicamente, cuando hablamos de la relación consumidor-marca, este proceso aparece, y las marcas tratan de transmitir esa información creíble a los usuarios. La marca transmite la 
información, que puede ser esta interpretada como positiva, negativa o neutral y en función de esa interpretación el usuario decidirá si tiene un mayor o menor ajuste con esa marca y si pretende comprometerse en mayor o menor medida con ella (Na, Kunkel, \& Doyle, 2019).

El concepto de credibilidad es claramente un elemento fundamental en el proceso de compra de los consumidores y también es un aspecto importante para la compañía, ya que la credibilidad sirve para mejorar el posicionamiento de la marca (Erdem \& Swait, 2004) siendo ese posicionamiento uno de los valores diferenciales frente a la competencia (Hanzaee \& Taghipurian, 2012) más si cabe hoy en día, con la gran competencia que hay y el crecimiento de las redes sociales. Por otro lado, la credibilidad también permite, junto con la sensación de que la marca es única, que los usuarios tengan una mayor intención de pagar precios premium (Dwivedi, Nayeem, \& Murshed, 2018), entendiéndola como el compromiso de la marca de cumplir con las promesas que realiza, de forma que los comportamientos pasados de la marca sirvan a los usuarios para predecir sus comportamientos futuros (Herbig \& Milewicz, 1995). Según Erdem y Swait (2004) este concepto de credibilidad se divide en dos elementos, por un lado, el trustworthiness que sería la voluntad que tiene la empresa de cumplir con las promesas que ha establecido y, por otro, el expertise, que corresponde a la capacidad que tiene la empresa de entregar aquello que ha prometido. Estos mismos autores sostienen que, para el consumidor, es mucho más importante la voluntad de la empresa de cumplir las promesas (trusworthiness) que la capacidad que tiene de hacerlo (expertise). Además de lo comentado, hay que puntualizar que 
dicha credibilidad debe sostenerse en el tiempo, ya que este concepto no tiene sentido entendido como un punto temporal determinado, sino que se basa en el valor acumulado de todas las acciones con las que la marca ha ido cumpliendo con anterioridad (Erdem, Swait, \& Louviere, 2002). La interacción repetida de los consumidores podrá formar esta sensación de credibilidad, provocando respuestas internas subjetivas y comportamentales (Dwivedi et al., 2018). Estos mismos autores sostienen que la esencia de la credibilidad de marca será la percepción de un rendimiento predecible y fiable a lo largo del tiempo, donde los consumidores evaluarán la marca en las fases de pre-compra, compra y post-compra. Por tanto, con lo expuesto anteriormente, queda claro que las marcas deben ser creíbles para posicionarse y para conseguir un valor diferencial respecto a la competencia, ya que la consecución de dicha credibilidad favorecerá el éxito de la compañía (Goldsmith, Laffety, \& Newell, 2000).

\subsection{Confianza en la marca}

En el ámbito de los servicios, encontramos experiencias intangibles que no pueden ser valoradas hasta que se consumen, a diferencia de los bienes tangibles que pueden ser examinados más fácilmente. Pero eso no quiere decir que el trabajo de la marca no deba hacerse, ya que es igualmente importante y se ha demostrado, por ejemplo, que cuando los consumidores perciben confianza de la marca, es posible determinar el grado en que dichos consumidores invierten en las marcas (Kim, Kim, \& Lee, 2019). La confianza tiene relación con otras variables, existiendo entre otras, una 
relación con la recomendación, donde la investigación científica ha demostrado que las recomendaciones negativas producen un impacto negativo en aspectos como la confianza, las actitudes o las intenciones de compra (Mauri \& Minazzi, 2013) por lo que las marcas deben trabajar para tratar de reducir estos efectos (Bhandari \& Rodgers, 2018).

Viendo estas referencias, resulta claro que la confianza en la marca es un elemento clave a la hora de comprar un producto, tanto a nivel físico como online, ya sea un bien o un servicio. En cuanto al concepto teórico, la confianza está relacionada con la credibilidad, ya que según Sobel (1985) la credibilidad debe ser previa a cualquier acción o señal que pueda ser influyente en los consumidores, para que posteriormente aparezca la confianza, que es el elemento más importante para que los consumidores tomen decisiones. Siguiendo con la conceptualización de la confianza en la marca, podemos entenderla mejor atendiendo a algunas de las definiciones que han ido perfilando este aspecto a lo largo del tiempo. Entre ellas, encontramos la definición de Zucker (1986) que entiende que la confianza está relacionada con la voluntad de los consumidores de creer en las acciones o palabras de una persona o asociación, en este caso, de la marca. Posteriores definiciones, entienden que la confianza en la marca es la sensación de seguridad que tienen los consumidores cuando interactúan con ella (Delgado-Ballester, Munuera-Alemán, \& Yagüe-Guillén, 2003), donde los consumidores, al ganar confianza, mejoran las expectativas o intenciones de dicha marca (Pauwels-Delassus \& Descotes, 2013). Esta confianza es el elemento que influye de manera potente en la relación entre un comprador y un vendedor (Kim \& Walker, 2013), por lo que, sin ella, 
construir una relación fuerte con el consumidor no será posible (Sahin, Zehir, \& Kitapçi, 2011).

En relación con el concepto de confianza, aparece otro aspecto a tener en cuenta que es el riesgo percibido. Autores como Moorman, Zaltman y Deshpande (1992) establecen que la confianza solo tiene sentido cuando existen situaciones de incerteza o riesgo, ya que dicha confianza será el elemento que reducirá la incerteza ante una relación comercial (Frasquet, Mollá, \& Ruíz-Molina, 2017). Este hecho aumenta su importancia si atendemos a los contextos de compra online, ya que los consumidores cada vez más hacemos uso de internet para la compra de bienes y servicios (Wang, 2019) siendo algo que actualmente se entiende como un comportamiento habitual. Además, buscamos información en fuentes externas cuando no tenemos mucha familiaridad con la marca o cuando consideramos que el producto que queremos comprar es difícil de evaluar (Parikh et al., 2015). A partir de esa información de las fuentes mencionadas, los consumidores podemos obtener elementos de valoración para evaluar el producto, relacionando esa información con el desarrollo de nuestras respuestas cognitivas (Plewa et al., 2015). Por tanto, conociendo que el aspecto de la confianza tendrá relación con el grado de riesgo que tenga una situación de compra, deberemos tratar de mejorar la confianza que el consumidor percibe de nuestra marca, con la intención de que sienta que, si surge un problema en ese proceso, la marca va a tratar de arreglarlo (Kim, Shin, \& Koo, 2018) cumpliendo con aquello que estaba previsto (Erciş et al., 2012). 


\subsection{Lealtad}

La lealtad es probablemente uno de los conceptos que más interés ha suscitado el interés en los gestores, tanto de servicios deportivos como de otras áreas, con el fin de entender qué podemos hacer para que nuestros consumidores sean leales a nuestra marca y nos elijan entre la multitud de marcas que existen. En muchas ocasiones, se explica cómo hacer para llegar a un nuevo target, como establecer la segmentación de nuestra población de interés, pero es igual de importante conocer cómo podemos retener a los clientes actuales, ya que esto tiene unos claros beneficios $(\mathrm{Wu}$, 2011) y sin ello el crecimiento de nuestra compañía estará comprometido. Para este fin, de un tiempo a esta parte, las empresas han desarrollado programas de lealtad que están orientados a mejorar la satisfacción de los consumidores, así como su compromiso a largo plazo, y en muchos casos plantean beneficios para aquellos miembros que han mostrado ser leales al servicio, ya sea a través de algún descuento o mediante la creación de sistemas de puntuación que posteriormente les recompensen (Aluri, Price, \& McIntyre, 2019). Además, el hecho de no ser capaces de retener clientes, hace que constantemente tengamos que estar reclutando nuevos usuarios, lo que no solo es un coste económico, sino también un desgaste continuo en la organización que no conseguiría tener una estabilidad para plantear otras propuestas. De hecho, si conseguimos un cierto grado de lealtad en nuestros usuarios y la situación económica es delicada y, por ejemplo, necesitamos subir el precio de un determinado servicio, se ha demostrado que los clientes leales serán menos sensibles a ese incremento (Calabuig et al., 2014) por lo que permite mayor flexibilidad de operaciones. 
El concepto de lealtad es muy fácil de entender, pero realmente complicado de predecir. Prueba de ello es que hoy en día no existe una fórmula mágica para retener a los clientes, pero poco a poco se van dando pasos en el entendimiento del comportamiento del consumidor en este sentido. Decimos que la lealtad es fácil de entender porque básicamente es definida por algunos autores como una repetición del proceso de compra (Andreassen \& Lindestad, 1998), pero lógicamente esta definición que se centra en el plano conductual, necesita ser complementada con aquellas que hablan de la disposición actitudinal, de forma que, si las circunstancias cambian en el mercado por cualquier motivo, el consumidor siga considerando nuestra marca como primera opción (Gremler \& Brown, 1996). En este sentido Bloemer y Kasper (1995) establecen la diferenciación entre lealtad verdadera y falsa. Por un lado, la lealtad verdadera será la repetición de compra fundamentada en una evaluación y elección de dicha marca y soportada por componentes psicológicos, lo que provoca el compromiso con la marca. Este concepto de compromiso, que aparece vinculado a la lealtad, es un aspecto que está relacionado con los factores sociales o psicológicos que hacer que una persona tenga cierta coherencia en sus comportamientos (Pritchard, Havitz, \& Howard, 1999), de ahí la asociación de términos. Por otro lado, la lealtad falsa haría referencia solamente a la repetición de compra, sin ese enlace psicológico anteriormente comentado. Siguiendo esta línea, Odin, Odin y ValetteFlorence (2001) establecen que podemos hablar de lealtad verdadera cuando el usuario, incluso percibiendo una clara diferencia entre las marcas, compra una determinada marca. Por tanto, la lealtad verdadera 
podría entenderse como la elección de una marca cuando las condiciones no son totalmente favorables para ella. Finalmente, cabe destacar que, con el auge de las nuevas tecnologías y el comercio electrónico, estos conceptos clásicos como la lealtad también se han adaptado, apareciendo estudios sobre la lealtad electrónica, también conocida como E-Loyalty (Jeon, \& Jeong, 2017; Purani, Kumar, \& Sahadev, 2019; Quan et al., 2020) que lógicamente cambia el paradigma y obliga a tener en cuenta otros elementos, para así poder comprender mejor el comportamiento de los usuarios, en este caso a través de internet.

\subsection{Word of Mouth}

El WOM, siglas de Word of mouth, es el vocablo anglosajón utilizado para referirse a lo que en castellano conocemos como recomendación, en este caso acerca de la compra de un determinado bien o servicio. A nivel conceptual, este elemento se entiende como una comunicación informal que se realiza entre los usuarios para tratar de evaluar un determinado bien o servicio (Westbrook, 1987). Autores como East et al. (2008) insisten en ese carácter informal del consejo que realiza una persona sobre otra acerca de un bien o servicio del que ha hecho uso. Este concepto del Word of mouth ha ido recibiendo una mayor atención tanto desde el punto de vista de la investigación como desde el punto de vista de los gestores (Sweeney, Soutar, \& Mazzarol, 2012) debido a que es un potente elemento de comunicación (Harrison-Walker, 2001). La recomendación es, por tanto, un elemento influyente, y hoy en día con el acceso a las redes sociales, es muy fácil ver las opiniones de otros usuarios sobre un bien o servicio, por 
lo que las marcas, tratan de fomentar esa recomendación entre sus usuarios (Asada \& Ko, 2016). Del mismo modo, dichas marcas tratan de evitar las recomendaciones negativas, ya que pueden afectar a la confianza, las intenciones de compra y las actitudes hacia la marca de los consumidores (Mauri \& Minazzi, 2013). Para ello, dado que, como se está comentando anteriormente, muchas de las recomendaciones que se dan en la actualidad se dan en el comercio electrónico, las marcas tratan de realizar ciertas acciones que minimicen las posibles recomendaciones negativas que pudieran surgir, como pueden ser el hecho de empatizar con los consumidores que no están satisfechos o devolver el dinero en aquellas compras que no se ajustan a lo esperado (Bhandari \& Rodgers, 2018) estrategias que se encuentran enmarcadas en lo que se conoce como CRM o customer relationship management (Das, \& Mishra, 2019; DenizciGuillet \& Shi, 2019; Skoumpopoulou \& Franklin, 2019; Sota, Chaudhry, \& Srivastava, 2020).

Siguiendo con lo expuesto anteriormente, para que se produzca una recomendación positiva y que nuestra marca pueda verse beneficiada de ello, será fundamental la satisfacción de los usuarios con el servicio, ya que dicha satisfacción supone un claro antecedente de la recomendación (Bitner, 1990). El interés de perseguir esta recomendación, tiene su clave en el hecho de que cuando existe una recomendación positiva sobre una determinada marca, la persona que recibe dicha información comienza a desarrollar una expectativa positiva sobre la calidad de ese producto y de dicha marca (See-to \& Ho, 2014). Por tanto, el Word of mouth puede entenderse como una opinión o recomendación sobre un determinado 
producto, que puede ser una herramienta influyente en el comportamiento de otros usuarios hacia dicha marca. Del mismo modo que cuando hablábamos de la lealtad, comentábamos el cambio de paradigma con el auge del comercio electrónico, la recomendación también se ha visto modificada, surgiendo lo que se conoce como $E$-WOM o recomendación electrónica (Chu, Lien \& Cao, 2019; Danniswara, Sandhyaduhita, \& Munajat, 2020; Hong, \& Pittman, 2020; Liu et al., 2019; Yen \& Tang, 2019). Este elemento es muy habitual, especialmente en las redes sociales, donde los usuarios y los potenciales usuarios comparten conversaciones para expresar sus visiones y opiniones sobre una determinada marca. La recomendación electrónica será por tanto cualquier enunciado positivo o negativo realizado por los usuarios de una determinada marca, pero en este caso realizado a través de internet, lo que permite llegar a una mayor cantidad de personas (Hennig-Thurau et al., 2004).

\subsection{Congruencia}

La congruencia de los consumidores con la marca es un elemento que tiene que ver con el nivel de coincidencia o ajuste entre la imagen de marca y la propia imagen del usuario (Alguacil, Crespo, \& Pérez-Campos, 2020). Por tanto, este concepto hace referencia a la similitud o no similitud entre los valores de una entidad y los propios valores del usuario (Hamilton \& Sun, 2005) ya que los usuarios utilizan las marcas para expresar su autoconcepto actual o ideal (Ekinci, Sirakaya-Turk, \& Preciado, 2013), por lo que cuando un consumidor realiza una compra, se siente mejor y más satisfecho si la marca que ha comprado es más similar a su autoconcepto actual o su 
autoconcepto deseado (Sirgy \& Su, 2000). Existen dos elementos que condicionan la congruencia con la marca, como son la coherencia interna y la autoestima (Sirgy, 1982). La coherencia interna hace que los consumidores traten de evitar comportamientos de compra que son contrarios a su propio autoconcepto, mientras que la autoestima motiva a los usuarios a conseguir mayores niveles de singularidad de su propia imagen (Abosag et al., 2019).

En relación a esto, y atendiendo a las teorías que se relacionan con la congruencia en el proceso de compra, vemos que dicha congruencia tiene relación con la teoría de la disonancia cognitiva de Festinger (1957). Esta teoría defiende que las personas (consumidores) tienden a actuar (comprar) de forma acorde a lo que piensan, por lo que cuando pretenden comprar un producto que no es acorde a su forma de pensar o a sus valores, se produce una disonancia cognitiva que solo tiene dos soluciones: el convencimiento de que sí que se debe comprar ese producto o el rechazo a la compra. En esta línea, Sirgy (1982) establece que los consumidores compran los productos que, además de satisfacer sus necesidades, son acordes a su propia imagen. Por ello, las marcas deben tener claro su público objetivo, para parecerse lo máximo posible a ellos o hacer que se acerquen a dicha marca las personas de un determinado perfil, ya que se ha demostrado que los consumidores se decantan más por aquellas marcas que les parecen similares a ellos (Kwak \& Kang, 2009). Además, cuando compramos marcas lo hacemos porque a través de esa compra creamos nuestra identidad o transmitimos lo que somos (Fournier, 1998) por lo que constituye una expresión social en la que también puede haber aspectos de 
aprobación social (Pitta \& Katsanis, 1995). Esta congruencia también será importante en los casos de patrocinio (Close, Krishen, \& LaTour, 2009) porque si la relación entre patrocinador y patrocinado es congruente, las asociaciones en la mente de los consumidores son más fuertes (Zdravkovic $\&$ Till, 2012) y facilitan el recuerdo. Aquí aparece un concepto clave en los procesos de patrocinio como es la transferencia de imagen (Alonso-DosSantos et al., 2016) que se produce entre los atributos de la marca del evento y del patrocinador, aunque como indican algunos autores, lo importante no solo será la congruencia sino la medición de la efectividad que tiene dicho patrocinio (Alonso-Dos-Santos, Calabuig, \& Crespo-Hervás, 2019). Además de lo comentado, la congruencia ha mostrado ser un elemento que muestra una relación influyente con el compromiso con la marca (Karampela et al., 2018), y también ha demostrado su importancia para la mejora de aspectos como la lealtad y las intenciones de recomendar la marca (Japutra, Ekinci, \& Simkin, 2019), por lo que claramente es un aspecto a tener en cuenta en la gestión de entidades.

\subsection{Actitudes hacia la marca}

Las actitudes hacia la marca son entendidas como una evaluación que los consumidores resumen en sus mentes con un carácter relativamente duradero, al contrario de los sentimientos que provoca la marca, que podrían ser transitorios (Spears \& Singh, 2004). Esta evaluación que realizan los consumidores a nivel interno, estará relacionada con las actitudes que generan hacia la marca, por lo que podrían afectar a su comportamiento (Woisetschläger Backhaus, \& Cornwell, 2017). Por tanto, 
si sabemos que la generación de actitudes influye en el comportamiento de los usuarios, debemos intentar conseguir actitudes favorables, ya que nuestras acciones generarán actitudes en una dirección determinada que puede ser favorable o desfavorable, pero nunca neutro (Ratnershwar \& Shocker, 1991). Para poder conseguir generar actitudes favorables hacia nuestra marca, debemos entender el concepto de actitudes dividido en tres componentes (Alexandris et al., 2008) uno cognoscitivo, que tiene que ver con el procesamiento consciente de la información, otro afectivo, que tendrá que ver con los sentimientos o emociones que nos despierta la marca y, un tercer elemento, que será el conativo, relacionado con la conducta, entendiendo que si la información que recibimos de una marca supera un determinado umbral, nos hará tener algún tipo de conducta hacia ella. Por otro lado, cuando la marca lleva a cabo conductas no adecuadas, las actitudes hacia ella se ven afectadas, así como las intenciones de recompra por parte de los consumidores (Huber et al., 2010). En este sentido, la comunicación a través de elementos como la publicidad puede ser un mecanismo para mitigar el impacto negativo que pudieran tener esas conductas inadecuadas realizadas por la marca (Ferrell et al., 2019).

Uno de los elementos necesarios para poder conseguir estas actitudes que se presumen tan importantes, es el posicionamiento de la marca, ya que a través de él podremos dar a conocer qué somos o qué nos representa y podremos hacer que los usuarios puedan percibir que somos diferentes a otras marcas con las que competimos en una misma categoría de producto (Castañeda-García et al., 2019). Con la intención de realizar una adecuada estrategia de posicionamiento o re-posicionamiento, las entidades centran 
sus esfuerzos iniciales en realizar un mapeo a través del cual poder tener información de la situación de la competencia de su marca. En ese análisis, además de conocer la situación de la competencia, se pueden examinar los comentarios y opiniones de los clientes acerca de los atributos que sirven de referencia para esas marcas pre-identificadas (Hu \& Trivedi, 2020) de forma que esa información resulte útil para la estrategia de posicionamiento que pretendemos llevar a cabo.

Las empresas, conociendo que las actitudes hacia la marca dependen de las asociaciones que de dicha marca tengan los usuarios, y que las asociaciones dependen en gran medida del posicionamiento que se haga de la marca (Aaker, 1996) tratarán de implementar distintos aspectos relacionados con la marca en sus estrategias de posicionamiento, intentando que esta marca sea asociada con aspectos funcionales, emocionales, simbólicos o relacionados con un estilo de vida (Zablocki, Schlegelmilch, \& Houston, 2019). Por tanto, si a través de ese posicionamiento y de una adecuada ejecución de las acciones de marketing, conseguimos transmitir las asociaciones que pretendemos, haremos más fácil la decisión de compra del consumidor (Romaniuk \& Gaillard, 2007).

\subsection{Calidad percibida}

El concepto de calidad percibida ha sido estudiado ampliamente en distintos ámbitos (Markovic et al., 2018; Yang et al., 2019) y de forma más reciente también en el contexto deportivo (Gálvez-Ruíz et al., 2018; García-Fernández et al., 2018; Jones, Byon, \& Huang, 2019). Cuando 
hablamos de calidad percibida, si hacemos referencia a las definiciones clásicas del concepto, entendemos este aspecto como una comparativa que realizan los consumidores entre las expectativas que tienen y lo que realmente consideran que reciben del bien o servicio que compran (Grönroos, 1984). Otros autores relevantes como Parasuraman, Zeithaml y Berry (1988) indican que la calidad tiene que entenderse como un juicio global que se realiza sobre un servicio para ver la superioridad que tiene respecto a otros. Esta calidad, en palabras de Lehtinen y Lehtinen (1982) se produce gracias a que en el servicio se produce una interacción entre los consumidores y la organización del servicio, encontrando la calidad física (equipamiento), la calidad corporativa (imagen de la empresa) y la calidad interactiva (contacto entre personal y consumidores).

Desde otro punto de vista, Zeithaml (1988) establece que la calidad percibida está relacionada con la excelencia o superioridad que tiene un producto respecto al resto de productos de esa categoría o de otras marcas. En esta línea, continuando con la conceptualización basada en la superioridad, encontramos la aportación de Monroe y Krishnan (1985) para quienes, en la calidad, dicha superioridad es medible y verificable bajo unos estándares determinados, si bien es cierto que a nivel de análisis del comportamiento de consumidor no solo conviene tener en cuenta la calidad objetiva, sino también la subjetiva (Zeithaml, 1988). De la misma forma, en relación a las clasificaciones, Grönroos (1982) diferencia entre la calidad técnica de un servicio y la calidad funcional del mismo, donde la primera haría referencia a lo que el consumidor recibe del servicio mientras que la segunda tiene que ver con qué beneficio funcional percibe el 
consumidor sobre ese servicio. Siguiendo con esta conceptualización de la calidad, y atendiendo en este caso la propuesta de Reeves y Bednar (1994), vemos que la calidad puede encuadrarse en distintos enfoques, en concreto estos autores proponen cuatro: el primero de ellos es el que entiende la calidad como excelencia, por lo que unos mejores resultados implicarán una mayor calidad. El segundo punto de vista establece que la calidad está relacionada con un valor, por lo que se extrae que la calidad no dependerá solo de la calidad que tenga el servicio que se presta, sino también del precio que tenga y de cómo perciban los usuarios la calidad del servicio en función de lo que pagan por él. El tercer enfoque atiende más a los estándares, es decir, a las especificaciones que debe conseguir una determinada marca ofreciendo un servicio, por lo que, si la marca consigue los estándares marcados, se podrá decir que tiene calidad. Finalmente, encontramos la cuarta visión, que relaciona la calidad con el cumplimiento de las expectativas de los clientes, y, por tanto, con su satisfacción (Muskat et al., 2019; Samudro et al., 2020).

\subsection{Valor percibido}

El valor percibido es un concepto que ha sido relacionado con otros elementos como con la calidad percibida y la satisfacción (Cronin, Brady, \& Hult, 2000), así como con la satisfacción y la lealtad (Yang \& Peterson, 2004) con la calidad percibida, las intenciones futuras y la satisfacción (Murray \& Howat, 2002) y de forma más reciente con aspectos de la marca como la congruencia (Kwak \& Kang, 2009) aunque estas relaciones con la marca, como se comentaba en la introducción de esta tesis doctoral, son 
bastante novedosas en el contexto deportivo y están aún por desarrollar. Entrando en la conceptualización del valor percibido, debemos decir que el análisis de este aspecto ha ido aumentando en los últimos tiempos, debido principalmente a que se ha entendido como un concepto clave para el éxito empresarial y para que las empresas puedan seguir siendo importantes (Sweeney \& Soutar, 2001). Además, el valor percibido ha sido analizado principalmente en relación con variables como la estrategia, el precio y el comportamiento del consumidor (Gil et al., 2006). A nivel conceptual, el valor percibido se ha mirado desde distintos enfoques. Entre esta variedad de perspectivas, podemos encontrar las que lo relacionan con el precio del producto (Kothandaraman \& Wilson, 2001; Sinha \& Desarbo, 1998; Zeithaml \& Zeithaml, 1984) o las que se centran en el intercambio entre lo que el consumidor recibe y lo que da y la percepción que el usuario tiene de esos beneficios (Bigné, Moliner, \& Callarisa, 2000; Chen \& Dubinsky, 2003; Wu \& Hsing, 2006). Como se comentaba al inicio de este apartado, el valor percibido ha sido relacionado con distintos aspectos y se ha convertido en un elemento de referencia, por lo que debemos intentar mejorarlo. Para ello, las empresas deben tratar de dar a los usuarios más beneficios y ahorrarle algún coste, de forma que su percepción del valor del servicio mejore y que la probabilidad de que la competencia gane espacio y los usuarios se planteen alternativas sea menor (Itani, Kassar, \& Loureiro, 2019). En el caso del contexto deportivo, este contexto es diferente a otros y tiene un carácter único, en el que los distintos actores que forman parte crean valor, encontrando entre estos agentes a la marca, los patrocinadores, las celebridades asociadas a la marca, las entidades 
colaboradoras o los fans (Kolyperas, Maglaras, \& Sparks, 2019). Para conseguir crear ese valor que se presupone tan beneficioso, actualmente las marcas están recurriendo a procesos de co-creación (Eriksson, 2019; Chang, 2019; Torfing, Sørensen, \& Røiseland, 2019) donde a través de la involucración voluntaria o involuntaria de los usuarios, se crean aspectos relacionados con el diseño, gestión o evaluación del servicio (Osborne, Radnor, \& Strokosch, 2016). Por tanto, según lo comentado, el valor percibido va un paso más allá de lo que planteaba el concepto de calidad percibida, ya que no solo es importante hasta qué punto el producto tiene calidad objetiva o es percibido como un producto de calidad, sino que entran en juego aspectos como lo que invierto en función de lo que recibo, lo que estoy dispuesto a pagar por un determinado producto o el esfuerzo o sacrificio que me supone dicha compra, por lo que la decisión del consumidor entraña más complejidad que simplemente ver si algo es de calidad o no.

\subsection{Satisfacción}

El último concepto que se define es el de satisfacción. Lógicamente cuando hablamos de servicios, en este caso en el contexto deportivo, la satisfacción es un elemento clave que debemos tener en cuenta, ya que ha sido demostrada su importancia en cuanto a la influencia que tiene sobre otros elementos, entre los que encontramos las actitudes hacia la marca y la lealtad (Russell-Bennet, McColl-Kennedt, \& Coote, 2007) la confianza en la marca (Delgado-Ballester \& Munuera-Alemán, 2001; Walter, Mueller, \& Helfer, 2000) así como las intenciones de compra (Alnawas \& Aburub, 
2016; Olsen \& Johnson, 2003) y las intenciones de recomendación que estos hacen del producto (Duarte, Silva, \& Ferreira, 2018; Söderlund \& Rosengren, 2007). En cuanto a la conceptualización de la satisfacción, numerosas definiciones hablan de ella como una evaluación que se realiza de las experiencias con el producto. Algunos hablan de una evaluación realizada de forma global tras la compra (Fornell, 1992) mientras que otros la definen como un conjunto de satisfacciones que se han ido obteniendo a través de las distintas experiencias con la marca (Yu \& Dean, 2001). Por otro lado, existen autores que incluyen las expectativas dentro de la explicación del concepto, al igual que pasaba con la calidad percibida, así, autores como Bloemer y Kasper (1995) o Bitner (1990) indican que la satisfacción tendrá que ver con una evaluación que realiza el usuario para comprobar en qué medida el producto ha satisfecho sus expectativas. Cuando hablamos de satisfacción, la marca también será importante, puesto que cualquier aspecto negativo que le ocurra a la marca puede provocar la insatisfacción de los usuarios (Andreassen \& Lindestad, 1998) de forma que todas las experiencias que tengamos en el proceso de compra, tanto antes, como durante y después, harán que exista o no satisfacción con el producto (Brakus, Schmitt y Zarantonello, 2009). 

CAPÍTULO III. OBJETIVOS E HIPÓTESIS DE LOS ESTUDIOS 



\section{OBJETIVOS E HIPÓTESIS}

En este apartado, con la intención de resumir de una forma clara el propósito de la tesis doctoral y de cada uno de los estudios que la componen, se muestran por un lado el objetivo general de la tesis y de las diferentes investigaciones y, por otro, las distintas hipótesis planteadas en los estudios que forman el compendio.

\subsection{Objetivo general de la tesis y objetivos de los estudios}

En este apartado, se muestra, en primer lugar, el objetivo general del compendio de publicaciones para, posteriormente, indicar de forma más concreta los objetivos que se persiguen en cada uno de los estudios planteados.

El objetivo general de la presente tesis doctoral es comprobar, mediante diferentes estudios, las relaciones entre las variables relacionadas con la marca en el contexto deportivo, así como la influencia de estas sobre las variables clásicas de servicio, con la intención de entender qué relaciones se establecen entre ellas y explicar en mayor medida cómo conseguir mejores niveles de lealtad y recomendación. Como se puede ver en la evolución de las publicaciones, la calidad formaba el inicio del primer modelo propuesto, para ver cómo esta se relacionaba con las variables de marca y comprobando la bidireccionalidad de algunas relaciones que pueden producirse entre marca y servicio, según el contexto. En posteriores estudios la marca pasa a ser el inicio de los modelos planteados, centrando 
el interés de comprobar que, dicha percepción de marca, puede ser el inicio de las posteriores tomas de decisiones de los consumidores, haciendo hincapié en que, desde la marca, sin necesariamente pasar por las variables clásicas de servicio, también se puede llegar a los resultados esperados.

A continuación, se muestran los objetivos específicos de los artículos realizados:

En el estudio 1 se pretende comprobar cuál es la influencia que tiene la calidad percibida de la marca de un servicio sobre la credibilidad que perciben los usuarios de ella y las actitudes que estos generan hacia dicha marca, para posteriormente conocer si existe una influencia significativa de las variables anteriormente comentadas sobre los niveles de lealtad y recomendación y, de ser así, en qué medida lo son.

En el estudio 2, el objetivo es introducir la confianza y la congruencia en el modelo clásico de servicio formado por las variables de calidad, valor y satisfacción, para comprobar mediante modelos de regresión jerárquica (HRM), si la capacidad predictiva de los modelos que tratan de explicar el valor percibido, la satisfacción y las intenciones futuras, mejora significativamente con la inclusión de dichas variables, en comparación con el modelo clásico. Posteriormente se realiza un análisis cualitativo comparativo (QCA) para conocer si existen variables necesarias para llegar al resultado esperado y cuáles son las interacciones suficientes que más permitan explicar dichos resultados de interés.

En el estudio 3, se plantea un modelo de ecuaciones estructurales mediante modelado de ecuaciones estructurales (SEM), en el que se parte de la 
congruencia del usuario con la marca, para testar si esa congruencia genera mayores niveles de credibilidad y de confianza, así como si estas variables influyen significativamente en la creación de una mejor disposición hacia la marca. Finalmente, se comprueba si las actitudes hacia la marca son predictoras de la lealtad que tendrán los usuarios hacia ella.

\subsection{Hipótesis de las investigaciones}

En cuanto a las hipótesis de las investigaciones encontramos, por un lado, relaciones que se plantean entre las variables de marca, ya que como se comentaba en la introducción, el ámbito de los servicios deportivos es un territorio poco investigado, por lo que resulta de interés ver cómo se relacionan las variables pertenecientes a la percepción de marca y si se confirman o no relaciones que han sido estudiadas en el ámbito del marketing general. Por otro lado, vemos también hipótesis que relacionan las variables de percepción de marca con las variables de percepción del rendimiento del servicio, para ver si existe relación significativa entre ellas $\mathrm{y}$ en qué medida, de forma que variables como la lealtad y la recomendación puedan ser explicadas en mayor medida partiendo de la imagen de marca de los usuarios.

En primer lugar, respecto al estudio 1 (ver tabla 1) encontramos un total de ocho hipótesis, que corresponden con las ocho relaciones propuestas, en las que, partiendo de la calidad percibida, se tratan de explicar, en primer lugar, las variables de credibilidad percibida y las actitudes hacia la marca, para 
posteriormente pasar a predecir la lealtad y la recomendación de los usuarios del servicio.

Tabla 1. Resumen de las hipótesis del estudio 1

The importance of the services brand in predicting loyalty and word of mouth

H1 La calidad percibida influye significativamente en la credibilidad

H2 La calidad percibida influye significativamente en las actitudes hacia la marca

H3 La credibilidad de marca influye significativamente en las actitudes

H4 La credibilidad de marca tiene una influencia sobre la lealtad

H5 Las actitudes influyen significativamente en la lealtad

H6 La credibilidad tiene una influencia significativa en el Word of Mouth

H7 Las actitudes influyen significativamente en el Word of Mouth

H8 La lealtad influye significativamente en el Word of Mouth

Por otro lado, en el segundo estudio (ver tabla 2), encontramos 3 hipótesis. La primera de dichas hipótesis plantea que, las que denominamos variables de marca, que en este caso son la confianza y la congruencia, serán capaces de predecir el valor percibido, la satisfacción y las intenciones futuras, de la misma forma que hasta ahora se ha hecho en las predicciones realizadas a partir de las variables clásicas de servicio: calidad percibida, valor percibido y satisfacción. En segundo lugar, encontramos el enunciado en el que se indica que, en alguno de los análisis de predicción de las variables anteriormente comentadas, las variables de confianza y congruencia tendrían un peso explicativo más alto que las variables clásicas de calidad percibida, valor percibido y satisfacción. Finalmente, la tercera hipótesis plantea que la confianza y la congruencia estarían presentes entre las combinaciones que más predicen los resultados esperados. 
Tabla 2. Resumen de las hipótesis del estudio 2

\section{Perceived value, satisfaction and future intentions in sport services: putting congruence and brand trust in the equation. Linear Models vs QCA}

Las variables relacionadas con la marca predicen significativamente el valor

H1 percibido, la satisfacción y las intenciones futuras de la misma forma que las variables clásicas relacionadas con el rendimiento del servicio

Las variables relacionadas con la marca tendrán un mayor peso predictivo en

$\mathrm{H} 2$ algunas predicciones que las variables de servicio que se han analizado principalmente en la literatura

La congruencia y la confianza estarán presentes en las combinaciones que permiten obtener los resultados esperados

Finalmente, el tercer estudio (ver tabla 3) plantea ocho hipótesis que comprueban cómo desde la congruencia, se puede generar credibilidad y confianza, mejorando las actitudes hacia la marca y su lealtad hacia ella.

Tabla 3. Resumen de las hipótesis del estudio 3

\section{Be Congruent and I Will Be Loyal: The Case of Sport Services}

La congruencia de marca tiene una influencia significativa y positive en la credibilidad de la marca

H2 La congruencia tiene una influencia significativa en la confianza en la marca

H3 La credibilidad de marca influye significativamente en la confianza

H4 La credibilidad afecta significativamente las actitudes de los usuarios hacia la marca

H5 La confianza en la marca influye significativamente en las actitudes hacia ella

H6 Las actitudes hacia la marca influirán significativamente en la lealtad de los usuarios hacia el servicio deportivo 



\section{CAPÍTULO IV. MÉTODO}





\section{MÉTODO}

\subsection{Población objeto de estudio y muestras de participantes}

El principal interés de los estudios, ha sido analizar la percepción de marca que tienen los usuarios de servicios deportivos y cómo esa percepción se relaciona con las variables de percepción de rendimiento de servicio. Por tanto, el objetivo ha sido encontrar información útil sobre cómo la percepción de la marca puede mejorar los niveles en los que se explican variables como la lealtad o la recomendación, entre otros, siendo elementos muy importantes para la sostenibilidad y crecimiento del servicio.

De forma más concreta, comentando las muestras utilizadas en cada uno de los trabajos, pasamos a detallar su composición:

En el estudio 1, titulado The Importance of the Services Brand in Predicting Loyalty and Word of Mouth, la muestra analizada corresponde a un total de 210 usuarios de un servicio deportivo público, de los cuales el $53.8 \%(\mathrm{n}=113)$ han sido mujeres y el porcentaje restante hombres $(46.2 \%$; $\mathrm{n}=97)$. El 29.4\% de los usuarios se encuentra entre los 18 y los 25 años, mientras que el $27.4 \%$ se encuentra entre 26 y 35 , el $20.1 \%$ entre 36 y 45 , el $13.2 \%$ entre 46 y 55 y el $9.8 \%$ tiene más de 55 años. La edad media ha sido de 35.58 años (DT=13.37), mientras que, del total, el 57.2\% utiliza el servicio 3 o más veces a la semana.

Por otro lado, en el estudio 2, titulado Perceived value, satisfaction and future intentions in sport services: putting congruence and brand trust in 
the equation. Linear Models vs QCA, la muestra de participantes ha sido de 683, de los cuales el 54,8\% $(n=374)$ han sido hombres y el 45,2\% $(n=309)$ mujeres. La media de edad en este caso ha sido de 36.18 años (DT=11.39). En relación a la titularidad del servicio, el $50.1 \%(n=346)$ pertenecían a un servicio público mientras que el $49.9 \%(n=344)$ lo hacía a un servicio privado. En cuanto a la frecuencia de asistencia, el 3.1\% (n=21) acude de forma ocasional (asistencia irregular), el $64.7 \%(n=435)$ lo hace de forma regular (una o dos veces a la semana) y el $32.1 \%$ acude al servicio de forma frecuente (más de 3 veces a la semana). En cuanto a la situación laboral, del total de usuarios el $58.4 \%(n=397)$ trabaja a tiempo completo, el $14 \%$ $(n=95)$ lo hace a tiempo parcial, el $23.1 \%(n=157)$ está desempleado y/o es estudiante y el $4.6 \%(n=31)$ son jubilados o pensionistas.

Finalmente, en el estudio 3, titulado Be Congruent and I Will Be Loyal: The Case of Sport Services, la muestra que se ha analizado ha sido de 307 usuarios de un servicio deportivo público, de los cuales 124 son hombres $(40.39 \%)$ y 183 mujeres (59.60\%). Del total de encuestados, el $7.82 \%$ $(n=24)$ se encuentran entre los 18 y 25 años, el $16.61 \%(n=51)$ entre los 26 y los 35 , el $28.99 \%$ ( $n=89)$ entre los 36 y los 45 , el $28.01 \%(n=86)$ entre los 46 y los 55 y el $21.82 \%$ ( $n=67)$ por encima de los 55 años. La edad media fue de 44.41 años (DT=12.93). En cuanto a la frecuencia de asistencia, los usuarios acuden 3.33 días a la semana de media $(\mathrm{DT}=1.31)$. Por último, respecto a la situación laboral, vemos cómo mientras que el $66.1 \%(n=203)$ se encuentra trabajando, el $12.7 \%(n=39)$ se encuentra en situación de desempleo, el 11,9\% ( $n=36)$ están jubilados y el 4,8\% (n=15) son estudiantes sin trabajo. 


\subsection{Instrumento}

Para la realización de los diferentes estudios, se creó un cuestionario a partir de la literatura existente en el ámbito, en este caso adaptado al caso concreto de los servicios deportivos. Este cuestionario fue validado en una investigación previa en la que se indicó que las escalas y, por tanto, los ítems utilizados en dicho instrumento, podían considerarse válidos y fiables para la medición de los distintos constructos de interés, tanto para los relacionados con la percepción de marca como para los relacionados con la percepción de rendimiento del servicio.

La encuesta creada consta de un total de 11 dimensiones (72 ítems) de las que 6 corresponden a la medición de la percepción de marca (actitudes hacia la marca, credibilidad, equidad o capital de marca, personalidad, congruencia y confianza) y 5 están más orientadas a la percepción del rendimiento del servicio (calidad percibida, la satisfacción, el valor percibido, la lealtad y la recomendación o Word of Mouth). Al final del apartado de las escalas, encontramos un apartado dirigido a obtener los datos sociodemográficos de las personas encuestadas. Dentro de estos datos, se ha recogido información sobre el género, la edad, la frecuencia de asistencia al servicio deportivo y la situación laboral, codificando posteriormente en rangos aquellas que así lo requerían, en concreto la edad y la frecuencia de asistencia. Las escalas que conforman el cuestionario tienen una escala de respuesta tipo Likert de 5 anclajes, donde el 1 significa estar muy en desacuerdo con la afirmación y el 5 muy de acuerdo con lo que propone el enunciado. 
Profundizando más en la creación de las escalas de medición de las distintas dimensiones, a continuación, se detalla el origen de los distintos enunciados que las forman. Del conjunto de apartados orientados a obtener información de la percepción de marca, la primera dimensión de la encuesta es la correspondiente a las actitudes, formada por siete ítems de los cuales los tres primeros surgen del trabajo de Gwinner y Bennet (2008) y los cuatro restantes de la aportación de Besharat (2010). La segunda dimensión, orientada a la credibilidad de marca (6 ítems) se ha obtenido de la contribución de Sweeney y Swait (2008) mientras que la tercera dimensión, dirigida a obtener información sobre la equidad de marca y que está compuesta por nueve enunciados, ha sido extraída del anteriormente comentado trabajo de Besharat (2010). La cuarta dimensión, que es la más extensa del cuestionario con 20 ítems, está orientada a la medición de la personalidad de marca, habiéndose extraído ese conjunto de ítems de la investigación llevada a cabo por Schlesinger y Cervera (2008) en la que adaptaron la escala original de Aaker (1997). La quinta dimensión es la dedicada a la congruencia del usuario con la marca, extrayendo los 4 ítems que la forman de la contribución de Grace y O'Cass (2005) mientras que, finalmente, la sexta dimensión que es la correspondiente a la confianza en la marca (tres ítems) se ha formado gracias a los enunciados obtenidos de la investigación de Hur, Kim y Kim (2014).

Por otro lado, atendiendo en esta ocasión a las dimensiones relacionadas con la percepción de rendimiento del servicio, encontramos en primer lugar la escala de calidad percibida (cuatro ítems) que se ha formado a partir de los enunciados de diferentes investigaciones (Buil-Carrasco \& Montaner- 
Gutiérrez, 2008; Lee \& Leh, 2011; Yoo \& Donthu, 2001). Por otro lado, encontramos la escala de valor percibido, creada gracias a cuatro enunciados propuestos por Hur et al. (2014) y la escala de satisfacción, que solamente consta de 2 ítems pero que son enunciados ampliamente utilizados y contrastados, en este caso obtenidos de Buil-Carrasco \& Montaner-Gutiérrez (2008) y de Bettencourt (1997). Finalmente, encontramos las dimensiones de lealtad hacia la marca y de recomendación. La escala de lealtad (cinco ítems) ha sido creada a partir de los enunciados de Yoo y Donthu (2001) así como de las contribuciones de Lee y Leh (2001) y de Tong y Hawley (2009) mientras que la escala de recomendación de la marca (Word of Mouth) surge de la adaptación de los ítems utilizados por Hightower, Brady y Baker (2002).

\subsection{Procedimientos}

En cuanto a los procedimientos que se han llevado a cabo para la recolección de los datos necesarios para la realización de las investigaciones, dado que la población objeto de estudio ha sido la misma, dichos procesos han sido similares. Evidentemente, el primer punto del proceso de recogida de la información fue la realización del cuestionario con las diferentes escalas de medida validadas. Una vez realizado, el siguiente paso consistía en ponerse en contacto con los servicios deportivos de interés en los que se pretendía recoger la información, hablando con los responsables para explicar la intención del estudio y, salvo inconvenientes, establecer los pasos a seguir. Tras el visto bueno por parte de la dirección del servicio, el siguiente paso fue informar al resto de empleados (técnicos, 
monitores...) de la realización de una investigación y de las fechas y horarios en los que se pretendía realizar. Esto permite que los empleados sean un elemento más de transmisión de la información, lo que hace que los usuarios estén al tanto de la realización de la investigación y de la importancia de contestar a la encuesta, aumentando la tasa de respuesta. Finalmente, en las fechas previstas, se comenzó a pasar las encuestas a los usuarios en diferentes horarios y actividades, yendo tanto a las actividades que así lo permitían, como intentando recoger encuestas de los usuarios que accedían o salían de la instalación, con la intención de recoger una muestra lo más amplia y heterogénea posible dentro de la homogeneidad que ya implica analizar un servicio deportivo. Dado que la encuesta era autoadministrada, el último paso que se debía realizar es la adecuada explicación de lo que se pretendía y cómo se debía contestar al cuestionario, estando atentos a que los usuarios lo rellenasen correctamente, evitando así cuestionarios nulos o con demasiados datos perdidos.

\subsection{Análisis estadístico}

Los diferentes artículos que forman el compendio de publicaciones se han llevado a cabo utilizando diferentes metodologías, siendo este uno de los puntos fuertes de la tesis doctoral. Entre ellas encontramos, en primer lugar, el uso del paquete estadístico SPSS para el cálculo de descriptivos y frecuencias, así como para los análisis mediante modelos de regresión jerárquica, que se encuadran dentro de los conocidos como modelos lineales. Por otro lado, también se han utilizado softwares estadísticos como EQS y QCA. El primero de ellos, EQS, pertenece a una metodología 
conocida como SEM (Structural Equation Modelling) y está orientado a la creación y posterior comprobación de modelos de ecuaciones estructurales, en los que se establecen diferentes relaciones entre las variables para ver su influencia y capacidad predictiva. Finalmente encontramos el software llamado QCA cuyas siglas se traducen en Qualitative Comparative Analysis, y que como su propio nombre indica está orientado al análisis cualitativo comparativo, una metodología diferente a la metodología cuantitativa pura que nos permite el establecimiento de ciertas relaciones entre variables y ciertas combinaciones que no son posibles con otras metodologías. A continuación, se explica de forma más detallada la metodología utilizada en cada uno de los artículos:

\subsubsection{Estudio 1. The importance of the services brand in predicting loyalty and word of mouth}

El primer estudio presentado tiene como objetivo analizar un modelo de ecuaciones estructurales que contiene como variables la calidad percibida, la credibilidad, las actitudes hacia la marca, la lealtad y la recomendación. En dicho modelo, se establecen una serie de relaciones que se deben testar (hipótesis). En este caso concreto, se ha querido comprobar la influencia de la calidad percibida por parte de los usuarios de un servicio deportivo para la mejora de la credibilidad de la marca y las actitudes que generan hacia ella, entendiendo que estos elementos mejorarán los niveles de lealtad de los usuarios y que dicha lealtad hará lo propio con las intenciones de recomendación. Para ello, en primer lugar, se ha realizado un análisis factorial confirmatorio, para comprobar que las escalas utilizadas cumplen con los criterios de fiabilidad y validez que establece la literatura. Una vez 
realizada dicha comprobación, se ha procedido a resolver el modelo estructural, donde se obtienen los valores de significación de las relaciones propuestas, así como la capacidad predictiva de dichas relaciones sobre una variable que se pretende conocer.

\subsubsection{Estudio 2. Perceived value, satisfaction and future intentions in} sport services: putting congruence and brand trust in the equation.

\section{Linear models vs QCA}

En el segundo de los estudios presentados, el objetivo ha sido analizar el papel de la congruencia con la marca y la confianza en ella dentro del modelo clásico formado por la calidad percibida, el valor percibido y la satisfacción. Para ello, se ha llevado a cabo un análisis mediante dos metodologías, utilizando por un lado los modelos de regresión jerárquica (en adelante HRM) en los que se han establecido tres modelos para predecir el valor, la satisfacción y las intenciones futuras. Posteriormente, se ha pasado a realizar un análisis cualitativo comparativo (en adelante QCA) para verificar la existencia de variables necesarias y suficientes para la consecución del resultado buscado. Por un lado, los modelos lineales realizados mediante HRM, nos permiten confirmar si las variables que incluimos dentro del modelo de calidad, valor y satisfacción, que en este caso son la congruencia y la confianza, mejoran o no la capacidad predictiva de los modelos planteados para explicar el valor, la satisfacción y las intenciones futuras y, por tanto, si el nuevo modelo propuesto permite predecir en mayor medida las variables de interés. El análisis QCA ayuda a conocer las variables que deben estar presentes obligatoriamente si se quiere obtener el resultado (necesarias) así como otras variables que pueden 
estar presentes en alguna de las combinaciones que producen el resultado que se busca, con la diferencia de que, sin ellas, otras combinaciones de variables también pueden llegar también al resultado esperado (suficientes).

\subsubsection{Estudio 3. Be congruent and I will be loyal: the case of sport services}

En tercer estudio, trata de comprobar si la percepción de marca, en concreto, la congruencia que sienten los usuarios con ella, puede ser un punto de partida para mejorar la credibilidad y la confianza en la marca, a partir del cual los usuarios puedan tener mejores actitudes hacia ella y por tanto mayor probabilidad de ser leales a la marca. Para ello, en primer lugar, se ha realizado un análisis factorial confirmatorio con el fin de comprobar que las escalas utilizadas cumplen con los criterios de fiabilidad y validez que sugiere la literatura. Posteriormente, se ha establecido un modelo de ecuaciones estructurales que plantea las distintas relaciones causales entre las variables, con el fin de comprobar si dichas relaciones resultan significativas o no, es decir, si son influyentes (y en qué medida lo son) y, por tanto, qué variables deben ser tenidas en cuenta de cara a mejorar otros aspectos de interés. 



\section{CAPÍTULO V. RESULTADOS Y DISCUSIÓN}





\section{RESULTADOS Y DISCUSIÓN}

\subsection{Resultados}

Siendo esta tesis doctoral un trabajo que muestra un compendio de publicaciones, a continuación, se muestran los resultados obtenidos en cada una de ellas, adjuntando los artículos con el formato en el que han aparecido publicados. 

5.1.1. Estudio 1. The importance of the services brand in predicting loyalty and word of mouth 



\title{
The Importance of the Services Brand in Predicting Loyalty and Word of Mouth
}

\author{
Mario Alguacil ${ }^{1}$, Juan Manuel Nunez-Pomar ${ }^{1}$, Irena Valantine $^{2}$, Josep Crespo-Hervas ${ }^{1}$, Carlos \\ Perez-Campos ${ }^{3}$, Inga Staskeviciute-Butiene ${ }^{2}$
}

${ }^{1}$ University of Valencia

FCAFE, Gasco Oliag, 3, 46010 Valencia, Spain

E-mail.aljima@alumni.uv.es,josep.crespo@uv.es,juan.m.nunez@uv.es

${ }^{2}$ Lithuanian Sports University

Sporto st., 6, Kaunas, Lithuania

E-mail.irena.valantine@lsu.lt,inga.staskeviciute@lsu.lt

${ }^{3}$ Catholic University of Valencia

Sacre Cor, 5, 46113, Godella, Spain

E-mail.carlos.perez@ucv.es

cross $^{\text {ref }}$ http://dx.doi.org/10.5755/j01.ee.29.4.17694

This research is related to brand perception and its implications for the management of services, especially for hedonic services. The aim of this study is to analyse the influence of perceived brand quality on credibility and attitudes towards this perceived quality from the point of view of users, as well as whether that relationship could trigger increased loyalty and recommendations. The survey was conducted with users of a public sports service located in Valencia, Spain, and the analysis of the data and the creation of the structural model was carried out using structural equation modeling (SEM). Its results have confirmed the influence of perceived quality on credibility but not on attitudes. On the other hand, the effects of credibility and attitudes on loyalty have been significant because of the influence of credibility on recommendations and attitudes. Conversely, attitudes have not had a direct influence on the word of mouth (WOM). This type of study, represent a novel contribution, because the studies of brand perception in sports services are practically non-existent, especially in the case of public sports services. In addition, the fact of using this type of methodology is in line with the most current works. Therefore, it supposes to contribute relevant information to the bibliography of this topic, and at the same time, it provides valuable information for managers, because if they have more information about how the variables are related and to what extent they do it, they will have more and better tools to be able to manage sports services more effectively and with less expenditure of resources, being able to plan more precisely the actions that they consider appropriate.

Keywords: Brand; Perceived Quality; Loyalty; WOM, Hedonic Services.

\section{Introduction}

Consumers who intend to purchase a new product or service have many suppliers from whom to obtain information, compare, and choose from (i.e., select the one that best suits their needs). The large number of offers and the ease with which consumers can access them, analyse them, and change them is generating more demanding clients. Furthermore, this phenomenon is forcing companies to make a greater effort towards meeting the customers' needs and creating something different from their competitors, which allows them to attract new customers and keep current ones. This situation also occurs in sports services, where user exigencies have grown in proportion to the sports market growth.

The sports industry has experienced a great growth in recent years, becoming a very important sector in some countries, in economic terms (in Spain it represents $2 \%$ of GDP) and above all in employment data (Ratten, 2018). The latest statistics provided by the European Commission (2013) show that sport generates $1.76 \%$ of gross value added and $2.12 \%$ of employment in the European Union. The data shown, indicate the great importance of sport and its potential to become a relevant industry, at the level of other more traditional industries such as the automobile or publishing industry. This growth means that there is a great demand for sport at the service level, so studies such as the one carried out here, allow us to draw conclusions for services in general and, above all, for the hedonic and leisure services industry. Upon reaching a point at which the user demands are satisfied but the company offers similar services as their competitors, brand image is very important for differentiation from competitors. As a brand, we need to evoke favourable and unique associations, and these different kinds of associations can affect how we operate in the marketplace (Brexendorf \& Keller, 2017). Brand image is defined as the set of meanings that allow an object to be known and through which people describe, remember, and relate (Dowling, 1986). It is a powerful tool, of which companies are aware, and it is important to try to improve it and keep a track of the process, because consumer's behaviour is affected by brand image (Burmann et al., 2008) so it is a key element to take into account.

The process of the creation and development of brand image has benefited from the rise of new technologies and 
social networks, which allows companies to have a flow of fast and easy communication with current and potential users and manage their relationship with them. This communication allows companies to make that relationship stronger and more durable, which, in terms of marketing, is known as CRM or customer relationship management, having an important link with loyalty (Carmen \& Marius, 2016; Nyadzayo \& Khajehzadeh, 2016). This process is obviously beneficial for companies because it allows for greater capacity for and ease of reaching the user and receiving feedback. At the same time, this process is inconvenient because the access of competitors to these benefits is equal. On the other hand, these actions are also beneficial for consumers, who now that have a direct and fast connection to the brand to express their views, interact and even participate in decisions concerning future company products. These actions may contribute to the process of cocreation, whereby value is generated on both sides as long as the consumer is able to customize their experience in the use of products or services and engage in specific tasks that companies offer (Piligrimiene et al., 2016).

When we talk about benefits of a working brand, we do not only mean the economic aspect, as it is not unique to the profit organizations. Other types of entities, such as non-governmental organization or public administrations, also resort to these activities in order to convey a better image, increase the perceived quality, or be more effective by linking users to different arising projects.

One of the problems linked to services, in terms of branding work, is that unlike goods, they suffer from intangibility, the provider offers a performance promise, which is intangible (Moeller, 2010) and this, along with the rest of elements within the well-known IHIP characteristics (heterogeneity, inseparability and perishability) makes it more difficult to evaluate. To alleviate the effect of this drawback, service brands are focused on simplifying the transmission of information with users, trying to use those aspects of service that may be useful to make them tangible. Some of these aspects may include the equipment in a sport centre (Parasuraman et al., 1985), merchandising, or the promotion of good treatment between customers and staff, who are an important and influential part in the opinion that users have about a service and who make the values of the brand palpable.

In short, many aspects can make a person feel more or less disposed to a brand, and many aspects also aid in customer loyalty after the good has been consumed or service has been completed. The purpose of this study is to provide information for a better understanding of the process of brand perception in services, and its relation to important variables for services management. Therefore, we want to contribute to help managers to know where they have to focus their efforts and investments, making their actions more effective and efficient, and consequently giving to users what they were looking for. This article describes some of the most important aspects of the brand, such as perceived quality, credibility, attitudes, loyalty, and Word of Mouth to test a model for observing the relationships established between the different factors, all framed in the field of sport facilities, particularly in public sports services.

\section{Literature Review and Hypotheses}

Perceived Quality. Perceived service quality can be defined as the view of the user on the level of excellence of a product (Zeithaml, 1988). The definition of this concept revolves around a common idea or vision, which refers to quality as the result after comparing what customers expect of the service and how they receive that service (Gronroos, 1984; Parasuraman et al., 1985, 1988).

Quality is a concept widely used by consumers in all areas, also in sports, but it can create confusion since in some cases, it can be difficult to define. The concept of quality is not so simple to understand, and the difficulty to delimit it is accentuated when we want to do it in the area of services because of the aforementioned intangibility. Unlike physical goods, there are little to no visible elements to observe, in order to make the valuation process easier. Perceived quality is a concept that may have objective elements to help to value it, but it remains a perception and thus brands can work to improve it.

It should also be noted that quality, unlike satisfaction, requires no previous experience with the brand or service to be perceived. Therefore, if a company is able to make its users perceive the brand as good quality, it will be more successful than those who do not obtain those associations, even if the product of the latter is objectively better because users in many cases do not have the ability to determine whether a product is better or worse than another.

In connection with the influences that can affect quality on other aspects, we found a remarkable link with loyalty. The connection between quality and loyalty has been studied by several authors, including Boulding et al. (1993), who found that there was a positive relationship between quality that had been perceived in service and repurchase intentions. The concept of quality has been investigated in different fields of services, such as in the case of airlines (Chang \& Yeh, 2002); however, if we focus on the sports field, we see a difference in the studied topics. For example, the research has included the perceived quality of the event (Crespo et al., 2012), perceived quality in leisure centres (Murray, Howat, 2002; Wakefield \& Blodgett, 2016), or its relationship with sports tourism (Thwaites, 1999). These different lines of research have led to the creation of new instruments of measurement and their validations, such as in the case of the EVENTQUAL scale (Calabuig-Moreno et al., 2016), which is a tool for measuring the perceived quality sporting events from the point of view of spectators. This type of tools bring richness to the literature on this subject and contribute to greater understanding of the construct in its various aspects.

H1: Perceived quality significantly influences credibility.

$\mathrm{H} 2$ : Perceived quality significantly influences attitudes towards the brand.

Brand Credibility. Brand credibility is defined as the believability of an entity's intentions at a particular time (Swait \& Erdem, 2007). In order to create brand credibility, it is necessary that consistency, clarity of the brand and investment over time be increased through all practices and aspects of marketing communications such as 
brand image advertising, sponsorship, or sales promotion (Jeng, 2016). Erdem and Swait (2004) show that the views of users and their considerations when they make a particular purchase are clearly influenced by credibility, so this aspect is very important in achieving future success in a company. Some aspects, such as time sensitivity and cumulative nature, characterize the company's credibility. In terms of time sensitivity in brand credibility, a consumer's perception of credibility today may be very different from the credibility that they will perceive a week later because it is a concept of variable nature. In terms of cumulative nature in brand credibility, the credibility of a brand is the cumulative effect of the actions that have been carried out over time and is not the effect of an isolated action of marketing (Erdem et al., 2002).

Moreover, brand credibility is not only trying to attract users but also the need to continue responding to the problems that may arise, avoiding losing the credibility from current customers (Bougoure et al., 2016). On the other hand, as Sobel (1985) suggests, if we want credibility, which can be perceived by users and have a significant impact, this must precede the actions that are carried out as a company. Therefore, to be really influential, we must be credible and able to show more users other benefits of our services.

Within the concept of credibility, several authors have agreed on dividing it into the following two aspects: trustworthiness, which would be the will of the company to deliver what it promises; and expertise, which refers to the ability of the company to carry out that intention (Erdem, Swait, 2004). According to these authors, trustworthiness is up to three times more important than expertise. Although both aspects are important, it is essential to show that you want to keep promises even more than show that you are able to do so. This brand credibility and acceptance are evaluated based on the following three dimensions, originally outlined by Ameri and Behnam (2014): experience of the organization, the reliability of the organization and the organization's attractiveness or convenience. If a company or organization is appropriate, innovative (i.e., experience), reliable, and able to attract long-term users (i.e., reliability) as well as attractive, entertaining, and worth its price (i.e., attractive or convenience), it will enjoy credibility from consumers. Brand credibility could be considered a key predictor in understanding future user behaviour, and consequently, it has been analysed in different areas and from different perspectives. We have found articles that study its role in the Chinese automotive industry ( $\mathrm{Li}$ et al., 2011) to influence consumer loyalty and improve word of mouth (Sweeney \& Swait, 2008).

H3: Brand credibility significantly influences attitudes.

$\mathrm{H} 4$ : Brand credibility significantly influences loyalty.

H6: Brand credibility significantly influences word of mouth.

Attitudes towards the brand. With the help of advertising, brands convey to users their features and benefits and that information reaches customers who, after analysing and evaluating, begin to create attitudes (i.e., positive or not) for that brand (Low \& Lamb, 2000). Brand attitude can be understood as the disposition that a customer has to a brand when known, without requiring use beforehand. It is the psychological tendency that is expressed when evaluating a certain entity with a certain degree of agreement or disagreement (Eagly \& Chaiken, 2007). Later, once the users decide to use the brand, if the experience satisfied them, those positive attitudes will be enhanced and will benefit the relationship between customers and brand, which can help to increase the likelihood of purchase intentions. It has been proven that the general perception of the brand is connected to attitudes (Ko \& Kim, 2014) and that attitudes have a positive impact on future purchase intentions (Shah et al., 2012).

Attitudes towards a brand will also be affected by social influence, as claimed by Keng et al. (2016). This aspect makes users have different attitudes and intentions of purchase due to the presence (i.e., physical or virtual) of other users in the context of purchase, either interacting with them or just with their mere presence.

Related to other aspects, several authors have studied the possible relationships that could affect attitudes towards the brand based on other users' behaviour. Nearly two decades ago, Farr and Hollis (1997) argued that attitudes are a precedent for future behaviour, and the fact of creating positive attitudes towards the brand is essential for long-term business success.

H5: Attitudes significantly influence loyalty.

H7: Attitudes significantly influence word of mouth.

Loyalty. Loyalty is a key element in the user-company relationship. The fact that customers are loyal, which makes them continue using the service, is the objective of any business. On the other hand, having loyal customers makes the company enjoy stability, and to some extent, not be continually striving to find new customers and trying to retain them. In recent decades this aspect of loyalty has been studied mainly from two perspectives: behavioural loyalty and attitudinal loyalty (Dick \& Basu, 1994). The former, behavioural loyalty or purchase loyalty, is related to the repeat of the purchase of the brand; whereas, the latter, attitudinal loyalty, includes a degree of dispositional commitment (Chaudhuri \& Holbrook, 2001).

Other definitions suggest that there is loyalty when favourable attitudes are greater and when there is a process of repetition of the same pattern (Dick \& Basu, 1994). Oliver (1999) states that loyalty is the profound intention of buying steadily in the future, while in more current definitions, we find contributions, such as John (2011), where the author understands loyalty as the feeling that makes consumers buy a product, service, or brand again and again. We must not forget that the fact that users are loyal is not only because of the functional benefits, but also the symbolic aspects are very influential (O'loughlin \& Szmigin, 2006).

Within the construct of loyalty, we found a conceptual difference between brand loyalty and inertia of purchase. It is true that when there is a phase of loyalty, there exists good disposition and inertial repurchasing patterns, which develop and facilitates loyalty behaviours (Evanschitzky \& Wunderlich, 2006). However, inertia is related to spurious 
loyalty and occurs when users show behavioural, but not attitudinal loyalty (Dick \& Basu, 1994). This action occurs when they repeat purchases of the same brand in a passive way, without much thought (White \& Yanamandram, 2004). Therefore, to be regarded as true loyalty, apart from the behaviour repurchase, there must be a psychological implication that will result in a commitment to the company. In order to achieve this implication, Pappu and Quester (2016) agree that brands must consider innovation as a key element. Once that commitment takes place, we will have more loyal customers, which will increase profits because of their repurchase intentions and also could attract new customers if they recommend the goods or services in a positive way.

In the field of loyalty, there have been studies on various subjects, including loyalty to a bank (Van EsterikPlasmeijer \& Van Raaij, 2017), loyalty in choosing destinations for travel (Yolal et al., 2017), loyalty to shops (Kim et al., 2017), or loyalty to professional sports teams (Kunkel et al., 2016).

H8: Loyalty significantly influences Word of mouth.

Word of mouth. In the sport industry, it is common to see organizations involved to try to enhance WOM among their users (Asada \& Ko, 2016). When a person makes use of a service, he or she obtains an opinion about the service and that opinion (which can be satisfactory or not) could be transmitted to their acquaintances. In addition, word of mouth is something well known because when you talk about a brand in a close circle, it is common for anyone who has had experience with it to advise or discourage their use. Therefore, Word of mouth is an opinion and recommendation that may end up being an influential tool in the behaviour of others with respect to goods or services.

In the literature, word of mouth is defined as informal advice (East et al., 2008) made to one person from another over a good or service that has been used. It also includes thoughts and ideas shared by people from their own events or experiences (Mikkelsen et al., 2003). Previous studies show how word of mouth is directly influenced by proportional loyalty levels, depending on the loyalty held by those responsible for word of mouth (Kumar \& Shah, 2004). Authors, such as Wang et al. (2010), have suggested this possibility and have also established that, depending on the levels of satisfaction, it is possible to find higher or lower levels of loyalty capable of positively influencing word of mouth.

\section{Methods}

Sample and procedure. A survey was performed with the intention to test a model and see the relationship between different factors related to the brand in this study. Data collection was performed in a public sports service in the city of Valencia, Spain, and the sample was selected by non-probabilistic sampling of intentional or convenience type, obtained from the users (i.e., over 18 years of age) who use the facilities of the municipal sports' service more or less frequently. Once the sample was analysed, it was found that $29.4 \%$ of respondents were between 18 and 25 years old, which comprised the majority of users, followed by age ranges $26-35(27.4 \%), 36-45$ (20.1\%), 46-55 $(13.2 \%)$ and over $55(9.8 \%)$. An average age of 35.58 years (SD 13.37) was obtained, consisting mostly of women $(53.8 \%)$. The total sample comprised 210 users, of which $57.2 \%$ made use of the service 3 or more times a week.

Measures. We developed a questionnaire based on studies with a similar theme, consisting of a list of items intended to measure the opinion of users on different aspects. It was divided into different coded sections made up of the following nine factors: attitudes, credibility, brand equity, brand personality, loyalty, consistency, Word of Mouth, service satisfaction and perceived quality. The study variables used for the proposed model were the five detailed in the theoretical framework (perceived quality, credibility, brand attitude, loyalty and Word of Mouth). Once the questionnaire was drawn up and reviewed by the research group in sports management at the University of Valencia, the questionnaire was administered in a personal and incidental way among the users of the sports services. The first part of the questionnaire consisted of statements about the brand and service, where users responded using the Likert scale according to their degree of agreement or disagreement with the statement (i.e., 1 = strongly disagree and $5=$ strongly agree). The last part of the survey included questions used for collecting socio-demographic data.

We then provided details on the items and sources that were used to develop the scales of analysed constructs in order of appearance on the survey. As the scope was not the same as the original, due to lack of specific literature, statements were adapted to ask about the purpose of the study, which analysed the brands of sports services. First, we determined the attitudes towards the brand, which was made up of 4 items collected from Gwinner and Bennet (2008). Then, we obtained a score for the following items on a scale 1 to 3 , corresponding with the following statements: I like the brand " $X$ "; " $X$ " is a very good brand; I have a favourable disposition towards " $\mathrm{X}$ " brand.

A fourth item was taken from Besharat (2010): My attitude towards this brand is very positive.

The second dimension corresponds to brand credibility, and within it, there are 3 items that have been obtained from the study about the effects of credibility on loyalty according to Sweeney and Swait (2008): (Service brand) delivers what it promises; $X$ claims about its service are believable; $X$ has a name you can trust.

The third dimension, which is part of the proposed model, is loyalty. To build this section, we used the scale of Yoo and Donthu (2001), which contains the following statements: I consider myself to be loyal to X; X would be my first choice; I will not buy other brands if $\mathrm{X}$ is available at the store.

The fourth dimension is related to Word of mouth. This part has four items that have been collected from two different studies. The first is Tong and Hawley (2009) from which we extract the first item: I would love to recommend $\mathrm{X}$ to my friends.

While the following three statements that complete this scale are the result of an adaptation from the original Hightower et al. (2002) study: I will recommend this sports center to my friends and family; I will speak positively about this sports center to other people if asked; I will encourage other people to go to this sports center. 
Finally, the fifth dimension that appears is the perceived overall quality. The items in this section have been obtained from Yoo and Donthu (2001), including the following statements: This is a high-quality sporting service; it is likely that the quality of this service is extremely high.

\section{Results}

Measurement model. A confirmatory factor analysis (CFA) was performed to test the reliability and validity of the constructs. Regarding the goodness of fit of the model, a Satorra-Bentler scaled Chi-squared value of 136.71 with 94 degrees of freedom was obtained, which provides a result of $\mathrm{X} 2 / \mathrm{gl}=1.45$ for the ratio, which is below 3 , and is therefore considered as good (Kline, 1998). In relation to the value of adjustment, indices were all higher than the criterion of 0.90 (Browne \& Cudeck, 1993; Hu \& Bentler, 1999) with the following results: NFI (0.94), NNFI (0.97), CFI (0.98) and IFI (0.98).

We can confirm that the RMSEA (root mean square error of approximation) met the established criteria because its value is 0.047 , which is below 0.08 , so an appropriate fit between measurement model and data was achieved (Browne, Cudeck, 1993; Hu, Bentler, 1999). By contrast, the coefficient of Mardia, which estimates the multivariate normality of the data by evaluating the multivariate kurtosis, did not obtain an acceptable result, as it exceeded 3, which is considered the limit to indicate there is no normality (Bentler, 2001). For that reason, we had to attend to the data obtained using the robust analysis method.

After analysing the results of convergent validity, the values of composite reliability (CR) and average variance extracted (AVE) for the perceived quality were 0.88 (CR) and 0.70 (AVE). On the other hand, in the variable credibility, they were 0.89 (CR) and 0.72 (AVE), while for attitudes towards the brand, they were 0.90 (CR) and 0.69 (AVE). Meanwhile, loyalty showed a result of 0.86 (CR) and 0.67 (AVE). Finally, Word of mouth obtained values of 0.94 (CR) and 0.84 (AVE). Convergent validity has been adequate in each element of the proposed structural model, with AVE values greater than 0.50 (Fornell \& Larcker, 1981) and composite reliability values higher than 0.70 (Hair et al., 2006). Table 1 shows a summary of data for each construct and also the values of $\mathrm{R} 2$.

Table 1

Convergent Validity

\begin{tabular}{|c|c|c|c|c|}
\hline Construct & Items & $\begin{array}{l}\text { Composite } \\
\text { Reliability }\end{array}$ & $\begin{array}{l}\text { Average variance } \\
\text { extracted }\end{array}$ & R2 \\
\hline \multirow{4}{*}{$\begin{array}{l}\text { Brand Attitude } \\
\text { (F3) }\end{array}$} & 1 & \multirow{4}{*}{0.90} & \multirow{4}{*}{0.69} & .689 \\
\hline & 2 & & & .763 \\
\hline & 3 & & & .691 \\
\hline & 4 & & & .619 \\
\hline \multirow{3}{*}{$\begin{array}{l}\text { Brand Credibility } \\
\text { (F2) }\end{array}$} & 10 & \multirow{3}{*}{0.89} & \multirow{3}{*}{0.72} & .798 \\
\hline & 11 & & & .749 \\
\hline & 12 & & & .616 \\
\hline \multirow{3}{*}{$\begin{array}{l}\text { Brand Loyalty } \\
\text { (F4) }\end{array}$} & 46 & \multirow{3}{*}{0.86} & \multirow{3}{*}{0.67} & .620 \\
\hline & 47 & & & .774 \\
\hline & 48 & & & .617 \\
\hline \multirow{4}{*}{$\begin{array}{l}\text { WOM } \\
\text { (F5) }\end{array}$} & 56 & \multirow{4}{*}{0.94} & \multirow{4}{*}{0.84} & .810 \\
\hline & 57 & & & .818 \\
\hline & 58 & & & .890 \\
\hline & 59 & & & .585 \\
\hline \multirow{2}{*}{ Quality (F1) } & 61 & \multirow{2}{*}{0.88} & \multirow{2}{*}{0.70} & .734 \\
\hline & 63 & & & .794 \\
\hline
\end{tabular}

Model and structural hypotheses. The questionnaire for conducting this study consists of a total of 9 constructs, as follows: brand attitude, credibility, brand equity, brand personality, loyalty, congruence, WOM, satisfaction, and overall perceived quality. As previously mentioned, to create this structural equation model, which would be the main part of the study, 5 dimensions were used (Figure 1). Due to the possible relationships that may exist between these factors, research hypotheses $\mathrm{H} 1$ to $\mathrm{H} 8$ arise.

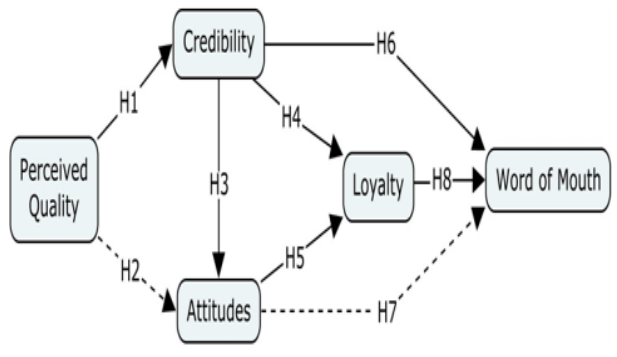

Figure 1. Structural Model of Hypothesis

The results of hypotheses (Table 2) show that the relationship between quality and credibility is significant (b $=0.82, \mathrm{t}=10.73$ ), which supports $\mathrm{H} 1$; while on the contrary, quality and attitudes show no significant relationship ( $\mathrm{b}=$ $0.21, \mathrm{t}=1.87$ ) so $\mathrm{H} 2$ is not supported. In the relationship between credibility and attitudes (H3), credibility and loyalty (H4), and attitudes and loyalty (H5), significant relationships were obtained in all of them $(b=0.63, t=5.41$, $\mathrm{b}=0.34, \mathrm{t}=3.09, \mathrm{~b}=0.50, \mathrm{t}=4.39$, respectively). Finally, it is noted that the relationship between credibility and word of mouth and the relationship between loyalty and word of mouth are both significant, supporting $\mathrm{H} 6$ and $\mathrm{H} 8(\mathrm{~b}=0.35$, $\mathrm{t}=2.68, \mathrm{~b}=0.55, \mathrm{t}=4.88$, respectively). Conversely, the relationship between attitudes and Word of mouth that forms $\mathrm{H} 7$ did not demonstrate significance $(\mathrm{b}=-0.22, \mathrm{t}=-0.17)$, making that hypothesis unsupported.

Table 2

Hypothesis Results

\begin{tabular}{|l|c|c|c|}
\hline \multicolumn{1}{|c|}{ Hypothesis } & $\begin{array}{c}\text { Standardized } \\
\text { Coefficient (Beta) }\end{array}$ & T Value & Conclusion \\
\hline $\begin{array}{l}\text { H1: Quality- } \\
\text { credibility }\end{array}$ & 0.82 & $10.73^{* *}$ & Supported \\
\hline $\begin{array}{l}\text { H2: Quality- } \\
\text { attitudes }\end{array}$ & 0.21 & 1.87 & Unsupported \\
\hline $\begin{array}{l}\text { H3: } \\
\text { Credibility- } \\
\text { attitudes }\end{array}$ & 0.63 & $5.41^{* *}$ & Supported \\
\hline $\begin{array}{l}\text { H4: } \\
\text { Credibility- } \\
\text { loyalty }\end{array}$ & 0.34 & $3.09^{* *}$ & Supported \\
\hline $\begin{array}{l}\text { H5: Attitudes- } \\
\text { loyalty }\end{array}$ & 0.50 & $4.39^{* *}$ & Supported \\
\hline $\begin{array}{l}\text { H6: } \\
\text { Credibility- } \\
\text { WOM }\end{array}$ & 0.35 & $2.68^{* *}$ & Supported \\
\hline $\begin{array}{l}\text { H7: Attitudes- } \\
\text { WOM }\end{array}$ & -.022 & -0.17 & Unsupported \\
\hline $\begin{array}{l}\text { H8: Loyalty- } \\
\text { WOM }\end{array}$ & 0.55 & $4.88^{* *}$ & Supported \\
\hline
\end{tabular}

Implications, limitations and future research. The results of this research are helpful in understanding the 
influence of the brand of hedonic services in the performance of the company in terms of user perception. This knowledge can help establish a set of predictors that serve to understand certain user behaviours in the future and also to show what aspects affect others, permitting knowledge of the most relevant aspects when attempting to achieve the objectives of the service. Therefore, analysis of brand perception provides valuable information for managers, and they are beginning to become aware of this concept, which is why an increasing number of services analyse and work their own brand, trying to provide customers with brand value to generate loyalty and increase purchase intentions and recommendations. In addition, analysis of brand perception not only has benefits in terms of repurchase of service and recommendations but also saves costs by making efficient investments since it allows a company to identify those aspects and to concentrate efforts on those aspects that have been proven as influential in modifying the behaviour of users and that are necessary to achieve our goals.

All research work has certain limitations that should be highlighted and considered. The main limitation of this work is in the sample studied, since it is not very large, which also refers to a specific sports' service. Although this limitation is common in this type of study, it would be very interesting to work with a larger sample and take in different sports services so that any difference between the different types of services can be analysed. Moreover, it would be interesting to investigate sports services that make an effort to improve the brand image and others that do not, and thus, to see if the future intentions of the users depend on the same or different factors.

Finally, an interesting future research study would be to analyse the influence of brand attributes on the future intentions of users in both public and private sports services after efforts are made to improve the service brand. This study would help in determining if the type of ownership has any influence on the valuation of the service provided.

\section{Discussion and Conclusions}

As mentioned above, the sport business is gaining great relevance in developed countries, and the conclusions of this study may be applicable to improve the service industry in general, but especially hedonic services.
In this study, we analyse how brand perception can trigger higher levels of loyalty and recommendation, including with the classic variables of quality, loyalty and recommendation, brand aspects that have shown their influence on these variables. Therefore, they provide evidence of the importance of the work of the brand to improve profitability in these types of companies, so they must be taken into account. Specifically, we investigated the influence of the brand quality perceived on aspects of credibility and the attitudes towards the brand. We also determined what actions of a company influence the future behaviours of the users, whether in the shape of loyalty towards the service or recommendations. The results indicate that the perceived quality positively influences the perception of credibility of the consumer, but not the users' attitudes towards this brand. The credibility significantly influences the users' attitudes towards the brand, and both affect the users' loyalty.

On the other hand, it has been observed that credibility directly affects Word of Mouth while attitudes do not show significant influence. Finally, loyalty has been shown to have a significant influence on WOM. From the applied point of view, this study provides a contribution to the scientific literature on the perception of brand in the hedonic and leisure services industry, in general, and specifically in sport services, which has been studied little by the marketing service providers. Besides, it provides an approach with a not very common methodology in this area such as the structure equation modeling (SEM), which allows the creation of structural models to understand the relationships and influences between variables. Speaking about managerial implications, this type of article responds to the increasing interest of service managers to know how brand image can serve them to be better perceived, to deliver a better service and to be able to differentiate themselves from other companies, which can give them that competitive advantage within the great offer that exists in the market and therefore increase their profits. In order with this, we think that future research lines of this topic should continue to be carried out to provide new information, of these variables, and also of others that may be influential. It would also be interesting to analyse the possible differences that can be found in the models created based on the type of service management.

\section{References}

Ameri, H. S., \& Behnam, M. (2014). The effect of brand credibility on consumers' perception about brands and their purchasing behaviors in sport goods. Sport Science, 7(2), 50-57.

Asada, A., \& Ko, Y. J. (2016). Determinants of word-of-mouth influence in sport viewership. Journal of Sport Management, 30(2), 192-206. https://doi.org/10.1123/jsm.2015-0332

Bentler, P. M. (2001). EQS 6 structural equations program manual. Encino, CA: Multivariate Software.

Besharat, A. (2010). How co-branding versus brand extensions drive consumers' evaluations of new products: A brand equity approach. Industrial Marketing Management, 39(8), 1240-1249. https://doi.org/10.1016/j.indmarman.20 10.02.021

Bougoure, U. S., Russell-Bennett, R., Fazal-E-Hasan, S., \& Mortimer, G. (2016). The impact of service failure on brand credibility. Journal of Retailing and Consumer Services, 31, 62-71. https://doi.org/10.1016/j.jretconser.2016.03.006

Boulding, W., Kalra, A., Staelin, R., \& Zeithaml, V. A. (1993). A dynamic process model of service quality: from expectations to behavioral intentions. Journal of Marketing Research, 30(1), 7-27. https://doi.org/10.2307/3172510 
Mario Alguacil, Juan Manuel Nunez-Pomar, Irena Valantine, Josep Crespo-Hervas, Carlos Perez-Campos, Inga

Staskeviciute-Butiene. The Importance of the Services Brand in Predicting Loyalty and Word of Mouth

Brexendorf, T. O., \& Keller, K. L. (2017). Leveraging the corporate brand: the importance of corporate brand innovativeness and brand architecture. European Journal of Marketing, 51(9/10), 1530-1551. https://doi.org/10.11 08/EJM-07-2017-0445

Browne, M. W., \& Cudeck, R. (1993). Alternative ways of assessing model fit, in Bollen, K. A., Long, J. S. (eds.), Testing structural equation model. Newbury Park, CA, Sage, 136-162.

Burmann, C., Schaefer, K., \& Maloney, P. (2008). Industry image: Its impact on the brand image of potential employees. Journal of Brand Management, 16(3), 159-176. https://doi.org/10.1057/palgrave.bm.2550112

Calabuig, F., Crespo-Hervas, J., Prado-Gasco, V., Mundina, J., Valantine, I., \& Stanislovaitis, A. (2016). Quality of sporting events: validation of the eventqual scale. Transformation in Business \& Economics, 15(2), 21-32.

Carmen, R., \& Marius, S. (2016). Customer loyalty using customer relationship management. Management Strategies Journal, 31(1), 285-288.

Chang, Y. H., \& Yeh, C. H. (2002). A survey analysis of service quality for domestic airlines. European Journal of Operational Research, 139(1), 166-177. https://doi.org/10.1016/S0377-2217(01)00148-5

Chaudhuri, A., \& Holbrook, M. B. (2001). The chain of effects from brand trust and brand affect to brand performance: the role of brand loyalty. Journal of Marketing, 65(2), 81-93. https://doi.org/10.1509/jmkg.65.2.81.18255

Crespo, J., Perez-Campos, C., \& Mundina, J. (2012). Calidad de servicio percibida por los espectadores de fútbol. Analisis de diferencias entre grupos [Spectators' perceived service quality of a football event. Analysing differences between groups]. Journal of Sports Economics \& Management, 2(1), 4-15.

Dick, A. S., \& Basu, K. (1994). Customer loyalty: toward an integrated conceptual framework. Journal of the Academy of Marketing Science, 22(2), 99-113. https://doi.org/10.1177/0092070394222001

Dowling, G. (1986). Managing your Corporate Images. Industrial Marketing Management, 15(2), $109-115$. https://doi.org/10.1016/0019-8501(86)90051-9

Eagly, A. H., \& Chaiken, S. (2007). The advantages of an inclusive definition of attitude. Social cognition, 25(5), 582602. https://doi.org/10.1521/soco.2007.25.5.582

East, R., Hammond, K., \& Lomax, W. (2008). Measuring the impact of positive and negative word of mouth on brand purchase probability. International Journal of Research in Marketing, 25(3), 215-224. https://doi.org/10.101 6/j.ijresmar.2008.04.001

Erdem, T., \& Swait, J. (2004). Brand credibility and its role in brand choice and consideration. Journal of Consumer Research, 31(1), 191-199. https://doi.org/10.1086/383434

Erdem, T., Swait, J., \& Louviere, J. (2002). The impact of brand credibility on consumer price sensitivity. International Journal of Research in Marketing, 19(1), 1-19. https://doi.org/10.1016/S0167-8116(01)00048-9

European Commission (2013). Study on the contribution of sport to economic growth and employment. Retrieved from: http://ec.europa.eu/assets/eac/sport/library/studies/study-contribution-spors-economic-growth-final-rpt.pdf

Evanschitzky, H., \& Wunderlich, M. (2006). An examination of moderator effects in the four-stage loyalty model. Journal of Service Research, 8(4), 330-345. https://doi.org/10.1177/1094670506286325

Farr, A., \& Hollis, N. (1997). What do you want your brand to be when it grows up: big and strong? Journal of Advertising Research, 36(6), 23-36.

Fornell, C., \& Larcker, D. (1981). Evaluating structural equation models with unobservable variables and measurement error. Journal of Marketing Research, 18(1), 39-50. https://doi.org/10.2307/3151312

Gronroos, C. (1984). A service quality model and its market implications. European Journal of Marketing, 18(4), 36-44. https://doi.org/10.1108/EUM0000000004784

Gwinner, K., Bennet, G. (2008). The impact of brand cohesiveness and sport identification on brand fit in a sponsorship context. Journal of Sport Management, 22(4), 410-426. https://doi.org/10.1123/jsm.22.4.410

Hair, J. F., Black, W. C., Babin, B. J., Anderson, R. E., \& Tatham, R. L. (2006). Multivariate data analysis (6th ed.), Upper Saddle River, NJ, Pearson Prentice Hall.

Hightower, R., Brady, M. K., \& Baker, T. L. (2002), "Investigating the role of the physical environment in hedonic service consumption: an exploratory study of sporting events". Journal of Business Research, 55(9), 697-707. https://doi.org/10.1016/S0148-2963(00)00211-3

Hu, L. T., \& Bentler, P. M. (1999). Cutoff criteria for fit indexes in covariance structure analysis: Conventional criteria versus new alternatives. Structural Equation Modeling: A Multidisciplinary Journal, 6(1), 1-55. https://doi.org/10.10 80/ 10705519909540118

Jeng, S. P. (2016). The influences of airline brand credibility on consumer purchase intentions. Journal of Air Transport Management, 55, 1-8. https://doi.org/10.1016/j.jairtraman.2016.04.005 
John, J. (2011). An analysis on the customer loyalty in telecom sector. Special reference to Bharath Sanchar Nigam limited, India. African Journal of Marketing Management, 3(1), 1-5.

Keng, C. J., Chang, W. H., Chen, C. H., \& Chang, Y. Y. (2016). Mere virtual presence with product experience affects brand attitude and purchase intention. Social Behavior and Personality, 44(3), 431. https://doi.org/10.2224/ sbp.2016.44.3.431

Kim, S. H., Kim, M., \& Holland, S. (2017). How customer personality traits influence brand loyalty in the coffee shop industry: the moderating role of business types. International Journal of Hospitality \& Tourism Administration, 1-25.

Kline, R. B. (1998). Principles and practice of structural equation modeling. New York, NY: The Guilford Press.

Ko, Y. J., \& Kim, Y. K. (2014). Determinants of consumers' attitudes toward a sport sponsorship: a tale from college athletics. Journal of Nonprofit \& Public Sector Marketing, 26(3), 185-207. https://doi.org/10.1080/1049 5142.2014.899811

Kumar, V., \& Shah, D. (2004). Building and sustaining profitable customer loyalty for the 21st Century. Journal of Retailing, 80(4), 317-330. https://doi.org/10.1016/j.jretai.2004.10.007

Kunkel, T., Doyle, J. P., Funk, D. C., Du, J., \& McDonald, H. (2016). The development and change of brand associations and their influence on team loyalty over time. Journal of Sport Management, 30(2), 117-134. https://doi.org/10.1 123/jsm.2015-0129

Li, Y., Wan, X., \& Yang, Z. (2011). The effects of corporate-brand credibility, perceived corporate-brand origin, and selfimage congruence on purchase intention: evidence from China's auto industry. Journal of Global Marketing, 24(1), 58-68. https://doi.org/10.1080/08911762.2011.545720

Low, G., \& Lamb, C. (2000). The measurement and dimensionality of brand associations. Journal of Product \& Brand Management, 9(6), 350-368. https://doi.org/10.1108/10610420010356966

Mikkelsen, M., Van Durme, J., \& Carrie, D. G. (2003). Viewers talking about television advertising: a supplementary measure of advertising effectiveness. Paper presented at the 32nd EMAC, Glasgow, 20-23rd May.

Moeller, S. (2010). Characteristics of services-a new approach uncovers their value. Journal of Services Marketing, 24(5), 359-368. https://doi.org/10.1108/08876041011060468

Murray, D., \& Howat, G. (2002). The relationships among service quality, value, satisfaction, and future intentions of customers at an Australian sports and leisure centre. Sport Management Review, 5(1), 25-43. https://doi.org/10.10 16/S1441-3523(02)70060-0

Nyadzayo, M. W., \& Khajehzadeh, S. (2016). The antecedents of customer loyalty: a moderated mediation model of customer relationship management quality and brand image. Journal of Retailing and Consumer Services, 30, 262270. https://doi.org/10.1016/j.jretconser.2016.02.002

Oliver, R. L. (1999). "Whence consumer loyalty? Journal of Marketing, 63, 33-44. https://doi.org/10.2307/1252099

O'Loughlin, D., \& Szmigin, I. (2006). Emerging perspectives on customer relationships, interactions and loyalty in Irish retail financial services. Journal of Consumer Behaviour, 5(2), 117-129. https://doi.org/10.1002/cb.39

Pappu, R., \& Quester, P. G. (2016). How does brand innovativeness affect brand loyalty? European Journal of Marketing, 50(1/2), 2-28. https://doi.org/10.1108/EJM-01-2014-0020

Parasuraman, A., Zeithaml V. A., \& Berry L. L. (1988). Servqual: A multiple-item scale for measuring consumer perceptions of service quality. Journal of Retailing, 64(1), 12-40.

Parasuraman, A., Zeithaml, V. A., \& Berry, L. L. (1985). A conceptual model of service quality and its implications for future research. Journal of Marketing, 49(4), 41-50. https://doi.org/10.2307/1251430

Piligrimiene, Z., Dovaliene, A., \& Virvilaite, R. (2015). Consumer engagement in value co-creation: what kind of value it creates for company? Inzinerine Ekonomika-Engineering Economics, 26(4), 452-460. https://doi.org/10.5 755/j01.ee.26.4.12502

Ratten, V. (2018). System Processes in Sport Entrepreneurship. In: Sport Entrepreneurship. Management for Professionals. Springer, Cham. https://doi.org/10.1007/978-3-319-73010-3

Schumacker, R., \& Lomax, R., (2004). A beginner's guide to structural equation modeling (2 ${ }^{\mathrm{a}}$ ed.), Mahwah, NJ: Lawrence Erlbaum Associates. https://doi.org/10.4324/9781410610904

Shah, S. S. H., Aziz, J., Jaffari, A. R., Waris, S., Ejaz, W., Fatima, M., \& Sherazi, S. K. (2012). The impact of brands on consumer purchase intentions. Asian Journal of Business Management, 4(2), 105-110.

Sharp, B. (1995). Brand equity and market-based assets of professional service firms. Journal of Professional Services Marketing, 13(1), 3-13. https://doi.org/10.1080/15332969.1995.9985201

Sobel, J. (1985). A theory of credibility. Review of Economic Studies, 52(4), 557-573. https://doi.org/10.2307/2297732

Swait, J., \& Erdem, T. (2007). Brand effects on choice and choice set formation under uncertainty. Marketing Science, 26(5), 679-697. https://doi.org/10.1287/mksc.1060.0260 
Mario Alguacil, Juan Manuel Nunez-Pomar, Irena Valantine, Josep Crespo-Hervas, Carlos Perez-Campos, Inga

Staskeviciute-Butiene. The Importance of the Services Brand in Predicting Loyalty and Word of Mouth

Sweeney, J. C., \& Swait, S. (2008). The effects of brand credibility on customer loyalty. Journal of Retailing and Consumer Services, 15(3), 179-193. https://doi.org/10.1016/j.jretconser.2007.04.001

Thwaites, D. (1999). Closing the gaps: service quality in sport tourism. Journal of Services Marketing, 13(6), 500-516. https://doi.org/10.1108/08876049910298766

Tong, X., \& Hawley, J. M. (2009). Measuring customer-based brand equity: empirical evidence from the sportswear market in China. Journal of Product \& Brand Management, 18(4), 262-271. https://doi.org/10.1108/10610 420910972783

Van Esterik-Plasmeijer, P. W., \& Van Raaij, W. F. (2017). Banking system trust, bank trust, and bank loyalty. International Journal of Bank Marketing, 35(1), 97-111. https://doi.org/10.1108/IJBM-12-2015-0195

Wakefield, K. L., \& Blodgett, J. (2016). Retrospective: The importance of servicescapes in leisure service settings. Journal of Services Marketing, 30(7), 686-691. https://doi.org/10.1108/JSM-08-2016-0291

Wang, Y. J., Hernandez, M. D., \& Minor, M. S. (2010). Web aesthetics effects on perceived online service quality and satisfaction in an e-tail environment: The moderating role of purchase task. Journal of Business Research, 63(9/10), 935-942. https://doi.org/10.1016/j.jbusres.2009.01.016

White, L., \& Yanamandram, V. (2004). Why customers stay: reasons and consequences of inertia in financial services. Managing Service Quality: An International Journal, 14(2/3), 183-194. https://doi.org/10.1108/09604520410528608

Yolal, M., Chi, C. G. Q., \& Pesamaa, O. (2017). Examine destination loyalty of first-time and repeat visitors at allinclusive resorts. International Journal of Contemporary Hospitality Management, 29(7).https://doi.org/10.110 8/IJCHM-06-2015-0293

Yoo, B., \& Donthu, N. (2001). Developing and validating a multidimensional consumer-based brand equity scale. Journal of Business Research, 52(1), 1-14. https://doi.org/10.1016/S0148-2963(99)00098-3

Zeithaml, V. A. (1988). Consumer perceptions of price, quality, and value a means-end model and Synthesis of evidence. Journal of Marketing, 52(3), 2-22. https://doi.org/10.2307/1251446

The article has been reviewed.

Received in March, 2017; accepted in October, 2018. 

5.1.2. Estudio 2. Perceived value, satisfaction and future intentions in sport services: putting congruence and brand trust in the equation. Linear models vs QCA 

ARLA

32,4

Received 10 April 2019 Revised 23 May 2019 25 September 2019 Accepted 25 September 2019

\section{Perceived value, satisfaction and future intentions in sport services Putting congruence and brand trust in the equation - linear models vs QCA}

\section{Valor percibido, satisfacción e intenciones futuras en los servicios deportivos \\ Poner congruencia y confianza de marca en la ecuación - Modelos lineales vs QCA}

\author{
Mario Alguacil \\ Catholic University of Valencia, Godella, Spain \\ Juan Núñez-Pomar \\ University of Valencia, Valencia, Spain \\ Carlos Pérez-Campos \\ Catholic University of Valencia, Godella, Spain, and \\ Vicente Prado-Gascó \\ University of Valencia, Valencia, Spain
}

\begin{abstract}
Purpose - The purpose of this paper is to analyze the role of brand-related variables as congruence and brand trust on the traditional model formed by perceived quality, perceived value (PV) and satisfaction, in order to compare predictive models for the variables of PV, satisfaction and future intentions of 683 users of sports services. Design/methodology/approach - The analysis has been carried out using two different methodologies. First, three models have been proposed to be analyzed by hierarchical regression models, in order to subsequently propose a fuzzy-set qualitative comparative analysis (fsQCA) to verify the existence or not of necessary and sufficient conditions.

Findings - The results indicate that both the classic service variables and the elements related to the brand significantly predict PV, satisfaction and future intentions, in some cases with greater predictive weight being given to congruence and trust than the classic service variables. In addition, linear models have been shown to improve their predictive capability by including brand-related variables, especially the future intentions model. After the fsQCA, congruence and trust have proved to be sufficient combinations to achieve high levels of PV and future intentions, while this is not the case for satisfaction.

Originality/value - The importance of the aspects related to the brand, either on their own or in combination with the classic service variables, is demonstrated, contributing to the literature on brand image in sports services, which is practically non-existent.
\end{abstract}

Keywords Consumer behaviour, Brand image, Hierarchical regression model, Qualitative comparative analysis, Sport services

Paper type Research paper

\section{Resumen}

Objetivo - El objetivo es analizar el papel de las variables relacionadas con la marca como la congruencia y la confianza en la marca en el modelo tradicional formado por la calidad percibida, el valor percibido y la 
satisfacción, con el fin de comparar modelos predictivos para las variables de valor percibido, satisfacción e intenciones futuras de 683 usuarios de servicios deportivos.

Diseño/Metodología/Enfoque - El análisis se ha llevado a cabo utilizando dos metodologías diferentes. En primer lugar, se han propuesto 3 modelos para ser analizados mediante modelos de regresión jerárquica, con el fin de proponer posteriormente un análisis comparativo cualitativo de conjuntos difusos para verificar la existencia o no de condiciones necesarias y suficientes.

Resultados - Los resultados indican que tanto las variables clásicas del servicio como los elementos relacionados con la marca predicen significativamente el valor percibido, la satisfacción y las intenciones futuras, en algunos casos con un mayor peso predictivo de la congruencia y la confianza que las variables clásicas de servicio. Además, se ha demostrado que los modelos lineales mejoran su capacidad predictiva al incluir las variables relacionadas con la marca, especialmente en el modelo de intenciones futuras. Después del análisis cualitativo comparativo, la congruencia y la confianza han demostrado ser combinaciones suficientes para lograr altos niveles de valor percibido e intenciones futuras, mientras que no ha sido así en el caso de la satisfacción. Originalidad/valor - Queda demostrada la importancia de los aspectos relacionados con la marca, por sí solos o en combinación con las variables clásicas del servicio, contribuyendo a la literatura sobre la imagen de marca en los servicios deportivos, que es prácticamente inexistente.

Palabras clave Análisis comparativo cualitativo, Modelos de regresión jerárquica, Imagen de marca, Servicios deportivos, Comportamiento del consumidor

Tipo de papel Trabajo de investigación

\section{Introduction}

Brand image is the element that allows all the effort, time and money invested by marketing managers, whether for goods or services, to be transmitted to consumers in a way that can lead to the success or failure of the company. Brand image should be understood as the set of aspects that we perceive of a brand, so it is equivalent at a conceptual level with brand perception, but should not be confused with the corporate image, which is a mistake that usually arises in research in this area. Through brand image, users perceive and interpret what we are and to what extent that fits with them and motivates them to carry out certain future intentions, so how we manage the brand is crucial. Throughout the literature there are numerous studies that have analyzed this aspect of brand image from different marketing approaches (Dwivedi and McDonald, 2018; Pham et al., 2018) but despite this, as stated by Bougoure et al. (2016) most studies are oriented to the analysis of goods while the scope of services, especially the context of sports services, remain largely unaddressed and leaves a number of important questions unanswered.

For this reason, the objective of this study is to compare predictive models for the variables of perceived value (PV), satisfaction and future intentions of users of sports services, to contribute to filling the gap that exists in the literature and provide evidence of the importance of brand trust (BT) and congruence for the improvement of classic variables in the service, all through an approach with different methodologies such as hierarchical regression models (HRM) and a fuzzy-set qualitative comparative analysis (fsQCA).

\section{Theoretical background}

The study of PV, satisfaction and future intentions has been a topic widely covered in the scientific literature related to services (Jin et al., 2015; Londoño et al., 2017; Murray and Howat, 2002; Wu and Li, 2017). Most existing models have been based on the analysis of the same classic variables of perception of service performance, such as perceived quality (PQ), value, satisfaction and future intentions (Su et al., 2016), leaving aside the possibility of incorporating other variables that may have an influence on these relationships, in this case brand congruence and BT.

Regarding the traditional variables within the quality models PQ has historically been understood as the excellence or superiority of a product and the consumer's judgment about it (Zeithaml, 1988). Grönroos (1984), for his part, establishes that the PQ corresponds to a comparison between the expectations that users have and what they really feel they receive.

Linear models vs QCA 
ARLA

32,4

568

On the other hand PV is defined as consumer perception of the overall benefits obtained and the cost of obtaining those benefits (Chen and Dubinsky, 2003), while satisfaction can be understood as an overall assessment by the consumer after purchase (Fornell, 1992) based on the consumer's consumption and purchasing experience over time (Anderson et al., 1994), as consumers rely on all their purchasing experiences over time when making purchasing decisions (Ha and Perks, 2005).

In the field of marketing, quality has been related throughout the literature mainly to PV (Sweeney et al., 1999), to value as a prior step to improving future intentions (Cronin et al., 1997) and to satisfaction (Chen and Chen, 2010). PV has been especially analyzed in relation to variables such as price, brand strategies and consumer behavior (Gil et al, 2006) PQ, satisfaction and future intentions (Murray and Howat, 2002) and also with satisfaction and loyalty (Yang and Peterson, 2004) but not with elements related to the brand in sports services, although it seems that aspects such as congruence and trust can have an influence on it. Satisfaction has also been studied in relation to other variables, such as attitudes toward the brand, future intentions of users and attitudinal loyalty (Russell-Bennett et al., 2007), its relationship with BT (Delgado-Ballester and Luis Munuera-Alemán, 2001), the relationship between satisfaction and repurchase intentions (Mittal and Kamakura, 2001) or the analysis of the expectations, satisfaction and loyalty of fitness club users (Pedragosa and Correia, 2009).

Brand congruence is an element that has been accepted both in terms of consumer attraction to the brand and in terms of attachment and loyalty (Karampela et al., 2018). Congruence, as Festinger's (1957) theory of cognitive dissonance explains, is based on the fact that people pretend to act as they think. This is why consumers are attracted to products that have a symbolic image similar to their own concept (Kwak and Kang, 2009) because they buy products that meet their needs, but are still coherent and consistent with their own image (Sirgy, 1982), which will make them more satisfied with the purchase (Bajac et al., 2018). Congruence has been studied mainly in relation to loyalty satisfaction (Jamal and Goode, 2001), the effectiveness of sponsorship (Alonso Dos Santos et al., 2019; Alonso Dos Santos and Calabuig, 2018), PV (Kwak and Kang, 2009) and attitudes toward the brand (Ghantous, 2016).

On the other hand, BT is also a fundamental aspect that must be analyzed, since in the buying process the relationship between buyer and seller is strongly influenced by the trust that exists between them (Kim and Walker, 2013) and is essential to build a strong relationship between the customer and the brand (Sahin et al., 2011). Trust is defined as the sense of security that the consumer possesses when interacting with a brand (Delgado-Ballester et al., 2003) mitigating the uncertainty in that business relationship (Frasquet et al., 2017). If a problem arises, this confidence will make the consumer believe that the brand will try to solve it (Kim et al., 2018) and the greater the confidence, the better the expectations will be of the brand's intentions (Pauwels-Delassus and Descotes, 2013), complying with the provisions (Erciş et al., 2012). Trust has been related to more traditional variables within the management of sports services, such as satisfaction, PV or quality of service (Kim and Peterson, 2017).

In the field of sport services, the relationships between the variables abovementioned have been little analyzed. Besides, most of the existing studies have focused on the so-called linear models, obviating other types of non-linear relationships which can be observed between these constructs such as the case of models based on fsQCA (Prado-Gascó et al., 2017). In general, in contrast with linear models, fsQCA offers the possibility of addressing multiple contextual causes in a straightforward manner, identifying combinations of multiple causes and get results more detailed that give us more horizontal complexity than the regression analysis (Vis, 2012). Besides, fsQCA offers more systematic fashion of analyzing complex causality and the logical relationships between causal conditions and a result than linear models (Legewie, 2013). Despite of this the literature recommends the use of both methodologies in a complementary manner (Calabuig et al., 2016; Giménez-Espert and Prado-Gascó, 2018; Villanueva et al., 2017). 
Summarizing and to establish the approach from which this research is carried out, as hypotheses for this paper we found a total of three:

H1. The variables related to the brand will significantly predict value, satisfaction and future intentions, as well as the classic variables related to service performance.

H2. The variables related to the brand will have greater weight in some predictions than the service variables that have been analyzed mainly in the literature.

H3. Congruence and trust will be present in the combinations to obtain the expected results.

Linear models vs QCA

\section{Method \\ Participants}

The sample is composed of 683 users of sports services aged 18 to 81 years, with an average age of 36.18 years (SD 11.39). The frequency of distribution users is 3.1 percent $(n=21)$ who come occasionally (less than once a week/irregularly), 64.7 percent $(n=435)$ who come regularly (once or twice a week) and 32.1 percent $(n=216)$ who come frequently (more than three times a week). Based on gender, we see how the sample is distributed among 54.8 percent men $(n=374)$ and 45.2 percent $(n=309)$ women. Regarding the employment situation, 58.4 percent $(n=397)$ work full time, 14 percent $(n=95)$ part-time, 23.1 percent $(n=157)$ are unemployed and 4.6 percent $(n=31)$ are retired. Finally, as regards the ownership of the center to which 50.1 percent $(n=346)$ belong to a publicly owned service, while 49.9 percent $(n=344)$ belong to a private service.

\section{Instrument}

In order to collect the information, a questionnaire was used with a Likert type response from 1 to 5 points. First, the congruence scale, taken from Grace and O'Cass (2005) and made up of four items. That scale showed adequate psychometric properties with a Cronbach's $\alpha$ of 0.80 (Hair et al., 2006) AVE values above 0.50 (Fornell and Larcker, 1981) and correlations between dimensions below 0.85 (Kline, 1998). These adequate psychometric properties hold for this study, with an $\alpha$ of 0.88 . Subsequently, we find the scale of trust and PV, with four items for each case, extracted from Hur et al. (2014) who adapted it from Chaudhuri and Holbrook (2001). The reliability and validity of the model was satisfactory (Hur et al., 2014). Also, in Chaudhuri and Holbrook (2001) where the value of Cronbach's $\alpha$ of BT was 0.81 and above 0.70 for PV (Hair et al., 2006). In our case with an $\alpha$ value of 0.92 and 0.85 , respectively. Regarding $\mathrm{PQ}$, the scale is made up of four items obtained from Buil-Carrasco and Montaner-Gutiérrez (2008), Lee and Leh (2011) and Yoo and Donthu (2001). First, the instrument of Buil-Carrasco and Montaner-Gutiérrez (2008) showed good properties in Cronbach's $\alpha$, composite reliability, AVE and the goodness-of-fit indicators: SB- $\chi^{2}(\mathrm{df})=$ 831.46(419); $\chi^{2} / \mathrm{df}=1.98 ; \mathrm{NFI}=0.88, \mathrm{NNFI}=0.92, \mathrm{CFI}=0.94 ; \mathrm{IFI}=0.94 ; \mathrm{RMSEA}=0.05$, $\alpha=0.90$. Regarding the contribution of Lee and Leh (2011) and Yoo and Donthu (2001), the scales showed adequate psychometric properties, with an $\alpha$ of 0.96 and 0.84 , respectively. In the case of our study, the scale produced an $\alpha$ of 0.89 . Regarding the statements of satisfaction, we find two items that have been extracted from Bettencourt (1997), confirming good reliability and validity, with a Cronbach's $\alpha$ value of 0.91 (Hair et al., 2006) and hold for this study with an $\alpha$ of 0.85 . Finally, the scale of future intentions was an adaptation of Hightower et al., the scale showed adequate psychometric properties in previous studies (Howat and Assaker, 2013) and also in this study, with a value of 0.94 on Cronbach's $\alpha$.

\section{Statistical analysis}

First, descriptive analyses of the participants were estimated, then, calibration values for fsQCA were calculated, after that, HRM and an fsQCA were performed. In the HRM, three models were calculated: general value, satisfaction and future intentions. On the other hand, 
ARLA

32,4

to perform the fuzzy-set qualitative comparative analysis, the raw data from participants' responses were transformed into fuzzy-set responses. First, as suggested on literature, all missing data were deleted, and all constructs (variables) are calculated by multiplying their item scores (Giménez-Espert and Prado-Gascó, 2018; Villanueva et al., 2017). Before performing the analysis, the values must be recalibrated between 0 and 1 . The recalibration is quite important because it may affect the final result, indicating more or fewer observations or participants that achieved a particular output. When we consider only two values, we proceed with 0 (not having the characteristic, fully outside the set) and 1 (having the characteristic, fully in the set). However, to perform the recalibration with more than two values, we must consider the following three thresholds: the first one (0) considers that an observation with this value is fully outside the set (low agreement); the second one (0.5) considers a median point, neither inside nor outside the set (intermediate level of agreement); and the last value (1) considers the observation to be fully in the set (high level of agreement). This process was the direct method of calibration proposed by the author of the methodology (Ragin, 2008), and it is the most used on literature (Barton and Beynon, 2015; Rey-Martí et al., 2016; Schneider and Wagemann, 2012; Woodside, 2013). With continuous variables or with factors from a survey (formed by different items), we must introduce these three values to proceed to an automatic recalibration of values between 0 and 1 . In these cases, the literature suggests that with continuous variables or with factors, the three thresholds must be percentiles 10, 50 and 90 (Woodside, 2013): 10 percent (low agreement or fully outside the set), 50 percent (intermediate level of agreement, neither inside nor outside the set), and 90 percent (high agreement or fully in the set). Once the responses have been transformed, as suggested by literature, necessary and sufficient condition tests were carried out. A sufficient condition expresses a combination of conditions that can produce a particular outcome although that particular outcome can be achieved by other combinations of conditions. Conversely, a condition is necessary when it must always be present for the occurrence of a particular outcome. According to Eng and Woodside (2012), to calculate sufficient conditions, the fsQCA analysis involves two stages: first, a truth-table algorithm transforms the fuzzy-set membership scores into a truth table that lists all logically possible combinations of causal conditions and each configuration's empirical outcome. Second, fsQCA analysis generates three possible solutions: complex, parsimonious and intermediate. The complex solution is the most restrictive, and the parsimonious solution is the least restrictive. Previous studies (Ragin, 2008) suggest including the intermediate solution (the solution that is presented here). When considering a sufficient analysis, as stated above, solution coverage considers variance explained (number of observations that can be explained by a particular combination of conditions), whereas solution consistency expresses a model's possible reliability or fit. In addition, when we consider each condition, raw coverage indicates how many cases or observations can be explained by the conditions (variance explained). Conversely, the unique coverage expresses the number of observations (variance) that can be explained by a particular combination of conditions but not by other combination of conditions. To choose the most important condition, we must consider the raw coverage. Regarding necessary analysis and similar to sufficient analysis, the consistency indicates the adequacy of the condition to predict a particular outcome $(\geqslant 0.90)$, whereas coverage considers variance explained by a condition (Ragin, 2008). SPSS (Statistical Package for the Social Sciences, Version 23, IBM) was used to perform descriptive analysis, calibration values and HRM, and fsQCA software (fuzzy qualitative comparative analysis, version 2.5, Raging and David, (Claude and Christopher, 2014)) was used to perform fsQCA.

\section{Results}

With the aim of knowing the predictive capacity of the different service quality variables and the variables related to the brand regarding future intentions, PV and satisfaction, 
the analyses were carried out using two different methodologies: on the one hand, the creation of linear models using multiple HRM and, subsequently, fsQCA.
Linear models vs QCA

\section{Hierarchical regression models (HRM)}

In terms of regression models, three hierarchical linear regressions were performed to predict PV, satisfaction and future intentions (see Table I). In all cases, two differential steps were considered: in the first step, the traditional sports quality management variables (PQ, PV and satisfaction (ST)] were included, while in the second step, the congruence (CG) and BT variables were included. First, in terms of predicting perceived value, in the first step of the regression quality was able to predict 55 percent of the value variance $\left(R^{2}=0.55\right.$; $R^{2}$ adj $\left.=0.55\right)$ with a weight of $0.74(\beta=0.74 ; p<0.001)$. In the second step, we included the variables related to the brand (congruence and trust), we observed that all the variables proposed in the regression model significantly explain the general value perceived by users $(F(550.95)=338.45 ; p<0.001)$. The second step model is capable of predicting 71 percent of the general value variance $\left(R^{2}=0.71 ; R^{2} \mathrm{adj}=0.71\right)$. As we can see, the variables that have more weight in the explanation of general value are BT $(\beta=0.47 ; p<0.001)$, followed by brand congruence $(\beta=0.27 ; p<0.001)$ and perceived quality $(\beta=0.18 ; p<0.001)$. Thus, this second step implies a change in $R^{2}$ of $0.16\left(\Delta R^{2}=0.16, p=0.000\right)$ by including the variables related to the brand. In the analysis of satisfaction, In the first step, including only perceived value and perceived quality, the model was able to explain 80 percent of satisfaction $\left(R^{2}=0.80 ; R^{2}\right.$ adj $\left.=0.80\right)$ where quality $(\beta=0.71 ; p<0.001)$ showed a greater predictive weight than value $(\beta=0.23 ; p<0.001)$. In the second step, including again brand congruence and BT, we can see that all the proposed variables predict satisfaction significantly $(F(743.78)=436.54 ; p<0.001)$. In this case, the second step model predicts 81 percent of satisfaction variance $\left(R^{2}=0.82 ; R^{2}\right.$ adj $\left.=0.81\right)$. The variable that have more weight in the explanation of satisfaction is perceived quality $(\beta=0.60 ; p<0.001)$ followed by BT $(\beta=0.17 ; p<0.001)$, brand congruence $(\beta=0.11 ; p<0.001)$ and perceived value $(\beta=0.10 ; p<0.001)$. Therefore, the inclusion of variables related to the brand implies a variation in the value of $R^{2}$ of $0.015\left(\Delta R^{2}=0.015 ; p=0.000\right)$ improving slightly the predictive capacity of the satisfaction model. Finally, regarding future intentions, in the first step where only perceived value and satisfaction were included the model was able to explain 66 percent of the variance of future intentions $\left(R^{2}=0.66 ; R^{2} \mathrm{adj}=0.66\right)$. With the second step, including again congruence and trust, all the variables of the model are significant $(F(350.02)=393.53 ; p<0.001)$ predicting 67 percent of future intentions variance $\left(R^{2}=0.67 ; R^{2}\right.$ adj $\left.=0.67\right)$. Perceived value has the highest weight

\begin{tabular}{|c|c|c|c|c|c|c|}
\hline \multirow{2}{*}{$\begin{array}{l}\text { Variable } \\
\text { Predictors } \\
\end{array}$} & \multicolumn{2}{|c|}{ Perceived value } & \multicolumn{2}{|c|}{ Satisfaction } & \multicolumn{2}{|c|}{ Future intentions } \\
\hline & $\Delta R^{2}$ & $\beta$ & $\Delta R^{2}$ & $\beta$ & $\Delta R^{2}$ & $\beta$ \\
\hline Step 1 & $0.55^{* * * *}$ & & $0.80 * * *$ & & $0.66 * * *$ & \\
\hline Perceived quality & & $0.74 * * *$ & & $0.71^{* * *}$ & & - \\
\hline Perceived value & & - & & $0.23^{* * *}$ & & $0.46^{* * * *}$ \\
\hline Satisfaction & & - & & - & & $0.40 * * *$ \\
\hline Step 2 & $0.16^{* *}$ & & $0.015^{* * *}$ & & $0.016^{* * * *}$ & \\
\hline Perceived quality & & $0.18^{* * *}$ & & 0.60 *** & & - \\
\hline Perceived value & & - & & $0.10 * *$ & & $0.33^{* * * *}$ \\
\hline Satisfaction & & - & & - & & $0.28 * * *$ \\
\hline Congruence & & $0.27 * * *$ & & $0.11^{* * * *}$ & & $0.06^{* *}$ \\
\hline Brand trust & & $0.47 * * *$ & & $0.17 * * *$ & & $0.22 * * *$ \\
\hline Total $R_{\text {adjusted }}^{2}$ & 0.71 **** & & $0.81^{* * * *}$ & & $0.67 * * *$ & \\
\hline
\end{tabular}

Notes: "-": not part of the analysis. * $p<0.05 ; * * p<0.01 ; * * * p<0.001$

Table I.

Hierarchical regression models (HRM) 
ARLA

32,4

572

Table II.

Descriptive statistics and calibration values $(\beta=0.33 ; p<0.001)$ followed by satisfaction $(\beta=0.28 ; p<0.001)$, BT $(\beta=0.22 ; p<0.001)$ and brand congruence $(\beta=0.06 ; p<0.05)$. These data imply a variation of 0.016 in the value of $R^{2}\left(\Delta R^{2}=0.016, p=0.000\right)$ after the inclusion of the elements related to the brand.

\section{Fuzzy-set qualitative comparative analysis ( $f_{S} Q C A$ )}

The qualitative comparative analysis was then carried out. First, the descriptive statistics and calibration values of the different variables that are part of the study were calculated using the fsQCA software (see Table II). Within this procedure and with the intention of maximizing the variance, the different calibration values have been obtained by multiplying the items of each of the scales that make up the instrument (Ragin, 2008).

Necessary conditions analysis for future intentions, perceived value and satisfaction. With respect to the necessary conditions analysis carried out for the variables of future intentions, perceived value and satisfaction (see Table IIII), we can observe how the results indicate that only the absence of perceived quality is necessary to achieve the dissatisfaction, since it is the only result that is placed with a value of 0.90 equaling the 0.90 criterion established by Ragin (2008).

Sufficiency conditions analysis for perceived value, satisfaction and future intentions. As for the sufficiency analysis, we have calculated the combinations of variables that allow for a high and low level of both the variable of perceived value, satisfaction and future intentions, indicating, as can be seen in Table IV, the three most important combinations for the achievement of each of the proposed results. The frequency cutoff was set at 1 , and consistency cutoffs ranged from 0.86 to 0.88 above the criterion of 0.74 (Eng and Woodside, 2012).

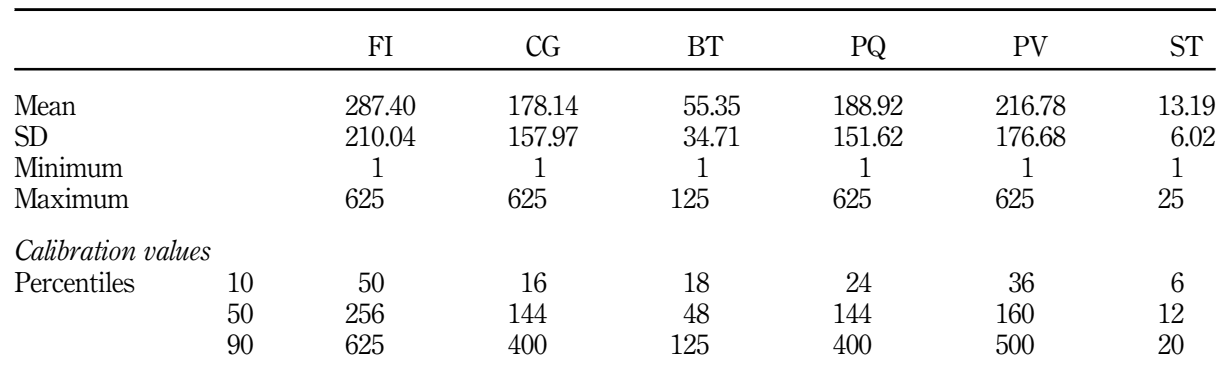

Notes: FI, future intentions; CG, congruence; BT, brand trust; PQ, perceived quality; PV, perceived value; ST, satisfaction

\begin{tabular}{lccccccccccccc}
\hline & \multicolumn{2}{c}{ PV } & \multicolumn{2}{c}{$\sim$ PV } & \multicolumn{2}{c}{ ST } & \multicolumn{2}{c}{$\sim$ ST } & \multicolumn{2}{c}{ FI } & \multicolumn{2}{c}{$\sim$ FI } \\
& Cons & Cov & Cons & Cov & Cons & Cov & Cons & Cov & Cons & Cov & Cons & Cov \\
\hline CG & 0.79 & 0.82 & 0.43 & 0.49 & 0.75 & 0.87 & 0.40 & 0.41 & 0.77 & 0.78 & 0.43 & 0.50 \\
$\sim \mathrm{CG}$ & 0.51 & 0.45 & 0.84 & 0.82 & 0.49 & 0.48 & 0.87 & 0.76 & 0.51 & 0.44 & 0.81 & 0.80 \\
$\mathrm{BT}$ & 0.83 & 0.85 & 0.42 & 0.48 & 0.77 & 0.89 & 0.39 & 0.39 & 0.80 & 0.81 & 0.43 & 0.50 \\
$\sim \mathrm{BT}$ & 0.50 & 0.44 & 0.87 & 0.85 & 0.47 & 0.47 & 0.89 & 0.77 & 0.50 & 0.43 & 0.83 & 0.83 \\
$\mathrm{PQ}$ & 0.83 & 0.80 & 0.47 & 0.49 & 0.85 & 0.91 & 0.40 & 0.38 & 0.82 & 0.77 & 0.46 & 0.49 \\
$\sim \mathrm{PQ}$ & 0.47 & 0.44 & 0.81 & 0.84 & 0.42 & 0.45 & 0.90 & 0.84 & 0.46 & 0.42 & 0.79 & 0.84 \\
$\mathrm{PV}$ & - & - & - & - & 0.77 & 0.87 & 0.41 & 0.41 & 0.82 & 0.80 & 0.43 & 0.49 \\
$\sim \mathrm{PV}$ & - & - & - & - & 0.47 & 0.48 & 0.86 & 0.77 & 0.48 & 0.42 & 0.83 & 0.84 \\
$\mathrm{ST}$ & - & - & - & - & - & - & - & - & 0.85 & 0.75 & 0.48 & 0.48 \\
$\sim \mathrm{ST}$ & - & - & - & - & - & - & - & - & 0.40 & 0.40 & 0.75 & 0.85
\end{tabular}

Table III.

Necessary conditions analysis for perceived value, satisfaction and future intentions
Notes: Cons, consistency; Cov, coverage; FI: future intentions; PV, perceived value; ST, satisfaction. $\sim$ : absence of condition. Condition needed: consistency $\geq 0.90$ 


\begin{tabular}{|c|c|c|c|c|c|c|c|c|c|c|c|c|c|c|c|c|c|c|c|}
\hline \multirow{2}{*}{$\begin{array}{l}\text { Frequency } \\
\text { cutoff: } 1\end{array}$} & \multicolumn{3}{|c|}{$\begin{array}{l}\text { FI } \\
\text { Consistency } \\
\text { cutoff: } 0.87\end{array}$} & \multicolumn{3}{|c|}{$\begin{array}{l}\quad \sim \mathrm{FI} \\
\text { Consistency } \\
\text { cutoff: } 0.87\end{array}$} & \multicolumn{3}{|c|}{$\begin{array}{c}\text { PV } \\
\text { Consistency } \\
\text { cutoff: } 0.87\end{array}$} & \multicolumn{3}{|c|}{$\begin{array}{l}\sim \mathrm{PV} \\
\text { Consistency } \\
\text { cutoff: } 0.88\end{array}$} & \multicolumn{3}{|c|}{$\begin{array}{c}\text { ST } \\
\text { Consistency } \\
\text { cutoff: } 0.88\end{array}$} & \multicolumn{3}{|c|}{$\begin{array}{c}\sim \mathrm{ST} \\
\text { Consistency } \\
\text { cutoff: } 0.86\end{array}$} & \multirow[t]{2}{*}{$\begin{array}{r}\text { Linear models } \\
\text { vs QCA }\end{array}$} \\
\hline & 1 & 2 & 3 & 1 & 2 & 3 & 1 & 2 & 3 & 1 & 2 & 3 & 1 & 2 & 3 & 1 & 2 & 3 & \\
\hline tisf & 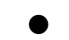 & - & • & - & - & - & & & & & & & & & & & & & \\
\hline lue & • & - & - & 0 & O & - & & & & & & & - & $\bullet$ & $\bullet$ & 0 & - & 0 & 573 \\
\hline $\begin{array}{l}\text { rceived } \\
\text { lality }\end{array}$ & - & - & $\bullet$ & - & - & 0 & $\bullet$ & • & - & - & 0 & 0 & $\bullet$ & - & - & 0 & 0 & 0 & \\
\hline trust & $\stackrel{\bullet}{-}$ & $\stackrel{\bullet}{\bullet}$ & $\begin{array}{l}- \\
-\end{array}$ & $\begin{array}{l}0 \\
-\end{array}$ & $\overline{0}$ & $\begin{array}{l}0 \\
-\end{array}$ & $\stackrel{\bullet}{-}$ & $\bar{\bullet}$ & $\stackrel{\bullet}{\bullet}$ & $\begin{array}{l}0 \\
0\end{array}$ & $\begin{array}{l}0 \\
-\end{array}$ & $\overline{0}$ & - & $\stackrel{\bullet}{-}$ & $\bar{\bullet}$ & ${ }_{-}^{0}$ & $\begin{array}{l}0 \\
0\end{array}$ & $\overline{0}$ & \\
\hline $\begin{array}{l}\text { nsistency } \\
\text { ww }\end{array}$ & 0.89 & 0.87 & 0.88 & 0.89 & 0.89 & 0.89 & 0.89 & 0.88 & 0.91 & 0.91 & 0.91 & 0.90 & 0.91 & 0.93 & 0.93 & 0.91 & 0.91 & 0.92 & \\
\hline ge & 0.69 & 0.69 & 0.71 & 0.76 & 0.73 & 0.73 & 0.74 & 0.72 & 0.71 & 0.77 & 0.76 & 0.73 & 0.84 & 0.68 & 0.66 & 0.77 & 0.77 & 0.76 & \\
\hline $\begin{array}{l}\text { coverage } \\
\text { Overall }\end{array}$ & 0.01 & 0.02 & 0.02 & 0.02 & 0.01 & 0.01 & 0.08 & 0.05 & 0.04 & 0.07 & 0.06 & 0.03 & 0.12 & 0.02 & 0.01 & 0.04 & 0.04 & 0.03 & \\
\hline $\begin{array}{l}\text { consistency } \\
\text { Overall }\end{array}$ & & 0.81 & & & 0.82 & & & 0.84 & & & 0.86 & & & 0.86 & & & 0.89 & & \\
\hline coverage & & 0.84 & & & 0.88 & & & 0.84 & & & 0.86 & & & 0.91 & & & 0.84 & & \\
\hline \multicolumn{19}{|c|}{$\begin{array}{l}\text { Notes: FI, future intentions; PV, perceived value; ST, satisfaction. } \boldsymbol{Q}=\text { presence of condition, } O=\text { absence of } \\
\text { condition. All sufficient conditions are adequate, raw coverage between } 0.65 \text { and } 0.77 \text {. } \sim: \text { low levels of } \\
\text { condition. Expected vector for future intentions: 1.1.1.1.1 (0: absent; } 1 \text { : present); expected vector for } \sim \text { future } \\
\text { intentions: } 0.0 .0 .0 .0 \text {; expected vector for perceived value: } 0.1 .1 .1 \text { (0: absent; } 1: \text { present); expected vector } \\
\text { for } \sim \text { perceived value: } 1.0 .0 .0 \text {; expected vector for satisfaction: } 1.1 .1 .1 \text {. (0: absent; } 1 \text { : present); expected vector } \\
\text { for } \sim \text { satisfaction: } 0.0 .0 .0 \text {. Using the format of Fiss (2011) }\end{array}$} & $\begin{array}{l}\text { Tabl } \\
\text { Sufficiency condi } \\
\text { analysis for } \mathrm{f} \\
\text { intentions, perce } \\
\text { value and satisfa }\end{array}$ \\
\hline
\end{tabular}

In predicting high and low levels of perceived value, we obtain three combinations that produce the expected result in each of them: for the case of achieving a high perceived value the most important combinations are the interaction of high levels of perceived quality and trust (raw coverage $=0.74$; consistency $=0.89$ ), high levels of quality and congruence (raw coverage $=0.72$; consistency $=0.88$ ) and high levels of trust and congruence (raw coverage $=0.71$; consistency $=0.91$ ), while for the achievement of low levels of perceived value, the best combinations are the interaction of low levels of trust and congruence (raw coverage $=0.77$; consistency $=0.91$ ), low levels of quality and trust (raw coverage $=0.76$; consistency $=0.91$ ) and low levels of quality and congruence (raw coverage $=0.73$; consistency $=0.90$ ).

For the high and low levels of satisfaction outcome variable, we find four combinations between the different variables to reach the expected result in each of them. In the case of achieving high levels of satisfaction, the most relevant combinations are high levels of perceived quality (raw coverage $=0.84$; consistency $=0.91$ ), high levels of perceived value and trust (raw coverage $=0.68$; consistency $=0.93$ ), and high levels of perceived value and congruence (raw coverage $=0.66$; consistency $=0.93$ ). On the other hand, to achieve low levels of satisfaction, the most important combinations are the interaction of low levels of value, quality and trust (raw coverage $=0.77$; consistency $=0.91$ ), low levels of quality, trust and congruence (raw coverage $=0.77$; consistency $=0.91$ ), and finally, low levels of value, quality and congruence (raw coverage $=0.76$; consistency $=0.92$ ).

Finally, for a high and low level of future intentions, we see that seven possible combinations are obtained that would produce the final result of high levels of future intentions or low levels. If we consider the achievement of a high level of future intentions, 
ARLA

32,4

the three most important combinations are the interaction of high levels of satisfaction, perceived value and trust (raw coverage $=0.69$; consistency $=0.89$ ), high levels of trust and congruence (raw coverage $=0.69$; consistency $=0.87$ ) and high levels of satisfaction, perceived value and perceived quality (raw coverage $=0.71$; consistency $=0.88$ ). On the other hand, the three most relevant combinations to achieve low levels of future intentions are the interaction of low levels of value and trust (raw coverage $=0.76$; consistency $=0.89$ ), low levels of perceived value and congruence (raw coverage $=0.73$; consistency $=0.89$ ) and low levels of perceived quality and trust (raw coverage $=0.73$; consistency $=0.89$ ).

\section{Discussion}

The results of this study are partly consistent with those of Calabuig et al. (2016), who analyzed the future intentions of spectators of a sports event and verify that quality, satisfaction and value predict future intentions, in our case the same thing happened, except in the case of perceived quality that is not part of the model. We also find the analysis of these variables in Murray and Howat (2002) where it is confirmed that satisfaction has a direct effect on future intentions, as well as an indirect effect, which is mediated by perceived value. Besides, the authors confirmed the direct effect of value on future intentions, with no indirect effect mediated by satisfaction. This agrees with our results and indicates that the variables that are part of the analysis may have more interrelationships with each other. In this sense, in the light of the study of Chen and Chen (2010) it was confirmed that both perceived value and satisfaction have significantly direct positive effects on behavioral intentions, with an indirect effect of experience quality on behavioral intentions mediated by both perceived value and satisfaction.

Prado-Gascó and Calabuig-Moreno (2016) analyzed linear models using HRM as well as fsQCA to observe the prediction of future intentions in spectators of a multi-sport event. Perceived value and satisfaction are shown to be significant predictors of future intentions, as is the case in the present study, but perceived quality is not. As for the fsQCA, specifically in the necessary conditions analysis, only a low level of perceived quality is shown to be necessary for low levels of satisfaction. In the case of future intentions, the interaction of high levels of value and satisfaction have been the variables closest to the criterion, but not necessary, as was the case in the work of Calabuig et al. (2016). On the other hand, with regard to the sufficiency conditions analysis, seven possible combinations were obtained for future intentions, three for perceived value and four for satisfaction, which contrasts with studies such as Prado-Gascó and Calabuig-Moreno (2016) where only the interaction of satisfaction and perceived value was obtained for future intentions.

\section{Conclusions}

The results indicate that in the prediction using linear models, both the classic service variables (quality, value and satisfaction) and those related to the brand (congruence and trust) significantly predict the result variables in the different models: perceived value, satisfaction and future intentions, supporting $H 1$. In addition, the inclusion of brand variables leads to improved prediction in all models, the most prominent being the predictive model of perceived value. In terms of regressions, in the case of perceived value, brand variables show greater predictive weight than quality (supporting H2), while in the case of satisfaction analysis, quality shows greater weight and brand elements follow, slightly above the perceived value. In future intentions, while congruence and trust show significance, perceived value and satisfaction offer the greatest weight. On the other hand, the results of qualitative comparative analysis indicate that the combination of trust and congruence in the absence of the rest of variables is not sufficient to obtain high levels of perceived value, satisfaction or future intentions, just the combination in the absence of trust 
and congruence is capable of obtaining low levels of perceived value. Thus, trust and congruence require the combination of variables such as quality, value and satisfaction to reach the result. In this case, we find that perceived quality in the analysis of satisfaction, and the combination of quality, satisfaction and value in future intentions, are the only options capable to achieve the result without the presence of brand-related variables, so $H 3$ is partially supported. Therefore, the results indicate that research related to perceived value, satisfaction and future intentions in services should consider aspects related to the brand such as congruence and trust within its models, given the importance they have shown to have in predicting these variables.

\section{Managerial implications}

As managerial implications, as the conclusions of this study stated, service managers, especially sports service managers, should not only focus on traditional variables to achieve the proposed objectives, but should also take into account new variables such as congruence and BT to ensure that users perceive a greater value, are more satisfied and have future intentions to continue using the service. This approach provides useful information in a context that remains largely unaddressed, allowing managers to know how variables relate to each other and how they interact to achieve the expected results, which in a way allows them to be more effective in the decisions they make and therefore achieve the objectives with less resources.

\section{Limitations and future research}

Regarding the limitations, the homogeneity and the size of the sample is the main one. Although the opinions of users of public and private services have been considered and different socio-demographic characteristics have been considered, it would have been interesting to obtain a larger and more heterogeneous sample, grouping, for example, the results depending on whether the service is public or private or considering the opinions of the users of services in different countries, which would have allowed us to verify possible differences based on the context or cultural aspects. As future lines of research, it would be interesting to solve these limitations.

\section{References}

Alonso Dos Santos, M. and Calabuig, F. (2018), "Assessing the effectiveness of sponsorship messaging: measuring the impact of congruence through electroencephalogram", International Journal of Sports Marketing and Sponsorship, Vol. 19 No. 1, pp. 25-40.

Alonso Dos Santos, M., Calabuig, F. and Sánchez-Franco, M. (2019), "Congruence and placement in sponsorship: an eye-tracking application”, Physiology \& Behavior, Vol. 200, March, pp. 159-165.

Anderson, E.W., Fornell, C. and Lehmann, D.R. (1994), "Customer satisfaction, market share, and profitability: findings from Sweden”, The Journal of Marketing, Vol. 58 No. 2, pp. 53-66.

Bajac, H., Palacios, M. and Minton, E.A. (2018), "Consumer-brand congruence and conspicuousness: an international comparison", International Marketing Review, Vol. 35 No. 3, pp. 498-517.

Barton, H. and Beynon, M.J. (2015), "Do the citizens of Europe trust their police?”, International Journal of Emergency Services, Vol. 4 No. 1, pp. 65-85.

Bettencourt, L.A. (1997), "Customer voluntary performance: customers as partners in service delivery", Journal of Retailing, Vol. 73 No. 3, pp. 383-406.

Bougoure, U.S., Russell-Bennett, R., Fazal-E-Hasan, S. and Mortimer, G. (2016), "The impact of service failure on brand credibility", Journal of Retailing and Consumer Services, Vol. 31, July, pp. 62-71.

Buil-Carrasco, I. and Montaner-Gutiérrez, T. (2008), "Factores clave en la formación de la actitud del consumidor hacia las extensiones de marca", Cuadernos de Estudios Empresariales, Vol. 18, pp. 109-134. 
ARLA

32,4

Calabuig, F., Prado-Gascó, V., Crespo-Hervás, J., Núñez-Pomar, J. and Añó, V. (2016), "Predicting future intentions of basketball spectators using SEM and fsQCA”, Journal of Business Research, Vol. 69 No. 4, pp. 1396-1400.

Chaudhuri, A. and Holbrook, M.B. (2001), "The chain of effects from brand trust and brand affect to brand performance: the role of brand loyalty", Journal of Marketing, Vol. 65 No. 2, pp. 81-93.

Chen, C.F. and Chen, F.S. (2010), "Experience quality, perceived value, satisfaction and behavioral intentions for heritage tourists", Tourism Management, Vol. 31 No. 1, pp. 29-35.

Chen, Z. and Dubinsky, A.J. (2003), "A conceptual model of perceived customer value in e-commerce: a preliminary investigation", Psychology \& Marketing, Vol. 20 No. 4, pp. 323-347.

Claude, R. and Christopher, R. (2014), “Acq (computer programme)”, University of Houston-Downtown, Houston, TX.

Cronin, J.J., Brady, M.K., Brand, R.R., Hightower, R. Jr and Shemwell, D.J. (1997), “A cross-sectional test of the effect and conceptualization of service value", Journal of Services Marketing, Vol. 11 No. 6, pp. 375-391.

Delgado-Ballester, E. and Luis Munuera-Alemán, J. (2001), "Brand trust in the context of consumer loyalty”, European Journal of Marketing, Vol. 35 Nos 11/12, pp. 1238-1258.

Delgado-Ballester, E., Munuera-Aleman, J.L. and Yague-Guillen, M.J. (2003), "Development and validation of a brand trust scale", International Journal of Market Research, Vol. 45 No. 1, pp. 35-53.

Dwivedi, A. and McDonald, R. (2018), "Building brand authenticity in fast-moving consumer goods via consumer perceptions of brand marketing communications", European Journal of Marketing, Vol. 52 Nos 7/8, pp. 1387-1411, doi: 10.1108/ejm-11-2016-0665.

Eng, S. and Woodside, A.G. (2012), "Configural analysis of the drinking man: fuzzy-set qualitative comparative analyses", Addictive Behaviors, Vol. 37 No. 4, pp. 541-543.

Erciş, A., Ünal, S., Candan, F.B. and Yıldırım, H. (2012), "The effect of brand satisfaction, trust and brand commitment on loyalty and repurchase intentions", Procedia-Social and Behavioral Sciences, Vol. 58, October, pp. 1395-1404.

Festinger, L. (1957), A Theory of Cognitive Dissonance, Stanford University Press, Stanford, CA.

Fiss, P.C. (2011), "Building better causal theories: a fuzzy set approach to typologies in organizational research", Academy of Management Journal, Vol. 54 No. 2, pp. 393-420, available at: https://doi. org/10.5465/AMJ.2011.60263120

Fornell, C. (1992), "A national customer satisfaction barometer: the Swedish experience”, The Journal of Marketing, Vol. 56 No. 1, pp. 6-21.

Fornell, C. and Larcker, D.F. (1981), "Structural equation models with unobservable variables and measurement error: algebra and statistics", Journal of Marketing Research, Vol. 18 No. 1, pp. 39-50.

Frasquet, M., Mollá Descals, A. and Ruiz-Molina, M.E. (2017), "Understanding loyalty in multichannel retailing: the role of brand trust and brand attachment", International Journal of Retail \& Distribution Management, Vol. 45 No. 6, pp. 608-625.

Ghantous, N. (2016), "The impact of services brand personality on consumer-brand relationship quality”, Services Marketing Quarterly, Vol. 37 No. 3, pp. 185-199.

Gil, I., Sánchez, M., Berenguer, G. and González-Gallarda, M. (2006), "Encuentro de servicio, valor percibido y satisfacción del cliente en la relación entre empresas", Cuadernos de Estudios Empresariales, Vol. 1 No. 15, pp. 47-72.

Giménez-Espert, M.d.C. and Prado-Gascó, V.J. (2018), "The role of empathy and emotional intelligence in nurses' communication attitudes using regression models and fuzzy-set qualitative comparative analysis models (fsQCA)", Journal of Clinical Nursing, Vol. 27 Nos 13-14, pp. 2661-2672.

Grace, D. and O'Cass, A. (2005), "Service branding: consumer verdicts on service brands", Journal of Retailing and Consumer Services, Vol. 12 No. 2, pp. 125-139. 
Grönroos, C. (1984), “A service quality model and its marketing implications”, European Journal of Marketing, Vol. 18 No. 4, pp. 36-44.

Ha, H.Y. and Perks, H. (2005), "Effects of consumer perceptions of brand experience on the web: brand familiarity, satisfaction and brand trust”, Journal of Consumer Behaviour, Vol. 4 No. 6 , pp. 438-452.

Hair, J.F., Black, W.C., Babin, B., Anderson, R.E. and Tatham, R.L. (2006), Multivariate Data Analysis, 6th ed., Prentice Hall, NJ.

Howat, G. and Assaker, G. (2013), "The hierarchical effects of perceived quality on perceived value, satisfaction, and loyalty: empirical results from public, outdoor aquatic centres in Australia”, Sport Management Review, Vol. 16 No. 3, pp. 268-284.

Hur, W.M., Kim, M. and Kim, H. (2014), "The role of brand trust in male customers' relationship to luxury brands”, Psychological Reports, Vol. 114 No. 2, pp. 609-624.

Jamal, A. and Goode, M.M. (2001), "Consumers and brands: a study of the impact of self-image congruence on brand preference and satisfaction”, Marketing Intelligence \& Planning, Vol. 19 No. 7, pp. 482-492.

Jin, N., Lee, S. and Lee, H. (2015), "The effect of experience quality on perceived value, satisfaction, image and behavioral intention of water park patrons: new versus repeat visitors", International Journal of Tourism Research, Vol. 17 No. 1, pp. 82-95.

Karampela, M., Tregear, A., Ansell, J. and Dunnett, S. (2018), "When opposites attract? Exploring the existence of complementarity in self-brand congruence processes”, Psychology \& Marketing, Vol. 35 No. 8, pp. 1-13.

Kim, M. and Walker, M. (2013), "The influence of professional athlete philanthropy on donation intentions", European Sport Management Quarterly, Vol. 13 No. 5, pp. 579-601.

Kim, M.S., Shin, D.J. and Koo, D.W. (2018), "The influence of perceived service fairness on brand trust, brand experience and brand citizenship behaviour”, International Journal of Contemporary Hospitality Management, Vol. 30 No. 7, pp. 2603-2621.

Kim, Y. and Peterson, R.A. (2017), “A meta-analysis of online trust relationships in E-commerce”, Journal of Interactive Marketing, Vol. 38, May, pp. 44-54.

Kline, R.B. (1998), "Software review: software programs for structural equation modeling: Amos, EQS, and LISREL”, Journal of Psychoeducational Assessment, Vol. 16 No. 4, pp. 343-364.

Kwak, D.H. and Kang, J.H. (2009), "Symbolic purchase in sport: the roles of self-image congruence and perceived quality”, Management Decision, Vol. 47 No. 1, pp. 85-99.

Lee, G.C. and Leh, F.C.Y. (2011), "Dimensions of customer-based brand equity: a study on Malaysian brands", Journal of Marketing Research and Case Studies, Vol. 2011 No. 2011, pp. 1-10, doi: 10.5171/2011.821981.

Legewie, N. (2013), “An introduction to applied data analysis with qualitative comparative analysis (QCA)”, Forum: Qualitative Social Research, Vol. 14 No. 3, pp. 1-45.

Londoño, B., Prado, Y. and Salazar, V. (2017), "Service quality, perceived value, satisfaction and intention to pay: the case of theatrical services", Academia Revista Latinoamericana de Administración, Vol. 30 No. 2, pp. 269-286.

Mittal, V. and Kamakura, W.A. (2001), "Satisfaction, repurchase intent, and repurchase behavior: investigating the moderating effect of customer characteristics", Journal of Marketing Research, Vol. 38 No. 1, pp. 131-142.

Murray, D. and Howat, G. (2002), "The relationships among service quality, value, satisfaction, and future intentions of customers at an Australian sports and leisure centre", Sport Management Review, Vol. 5 No. 1, pp. 25-43.

Pauwels-Delassus, V. and Descotes, R.M. (2013), "Brand name change: can trust and loyalty be transferred?", Journal of Brand Management, Vol. 20 No. 8, pp. 656-669.

Pedragosa, V. and Correia, A. (2009), "Expectations, satisfaction and loyalty in health and fitness clubs", International Journal of Sport Management and Marketing, Vol. 5 No. 4, pp. 450-464.
Linear models vs QCA 
ARLA

32,4

Pham, M., Valette-Florence, P. and Vigneron, F. (2018), "Luxury brand desirability and fashion equity: the joint moderating effect on consumers' commitment toward luxury brands", Psychology \& Marketing, Vol. 35 No. 12, pp. 902-912, doi: 10.1002/mar.21143.

Prado-Gascó, V., Calabuig Moreno, F., Añó Sanz, V., Núñez-Pomar, J. and Crespo Hervás, J. (2017), “To post or not to post: social media sharing and sporting event performance", Psychology \& Marketing, Vol. 34 No. 11, pp. 995-1003.

Prado-Gascó, V.J. and Calabuig-Moreno, F. (2016), "Measuring service quality of sporting events: lineal models vs QCA", Journal of Sports Economics \& Management, Vol. 6 No. 3, pp. 126-136.

Ragin, C.C. (2008), Redesigning Social Inquiry: Fuzzy Sets and Beyond, University of Chicago Press, Chicago, IL.

Rey-Martí, A., Ribeiro-Soriano, D. and Palacios-Marqués, D. (2016), "A bibliometric analysis of social entrepreneurship”, Journal of Business Research, Vol. 69 No. 5, pp. 1651-1655, available at: https://doi.org/10.1016/j.jbusres.2015.10.033

Russell-Bennett, R., McColl-Kennedy, J.R. and Coote, L.V. (2007), "Involvement, satisfaction, and brand loyalty in a small business services setting”, Journal of Business Research, Vol. 60 No. 12, pp. 1253-1260.

Sahin, A., Zehir, C. and Kitapçi, H. (2011), "The effects of brand experiences, trust and satisfaction on building brand loyalty: an empirical research on global brands", Procedia-Social and Behavioral Sciences, Vol. 24, pp. 1288-1301.

Schneider, C. and Wagemann, C. (2012), Set-Theoretic Methods for the Social Sciences A Guide to Qualitative Comparative Analysis, Cambridge University Press.

Sirgy, M.J. (1982), "Self-concept in consumer behavior: a critical review", Journal of Consumer Research, Vol. 9 No. 3, pp. 287-300.

Su, L., Swanson, S.R., Chinchanachokchai, S., Hsu, M.K. and Chen, X. (2016), "Reputation and intentions: the role of satisfaction, identification, and commitment", Journal of Business Research, Vol. 69 No. 9, pp. 3261-3269.

Sweeney, J.C., Soutar, G.N. and Johnson, L.W. (1999), "The role of perceived risk in the quality-value relationship: a study in a retail environment", Journal of Retailing, Vol. 75 No. 1, pp. 77-105.

Villanueva, L., Montoya-Castilla, I. and Prado-Gasco, V. (2017), "The importance of trait emotional intelligence and feelings in the prediction of perceived and biological stress in adolescents: hierarchical regressions and fsQCA models", Stress, Vol. 20 No. 4, pp. 355-362, available at: https://doi.org/10.1080/10253890.2017.1340451

Vis, B. (2012), "The comparative advantages of fsQCA and regression analysis for moderately large-N analyses", Sociological Methods \& Research, Vol. 41 No. 1, pp. 168-198.

Woodside, A.G. (2013), "Moving beyond multiple regression analysis to algorithms: calling for adoption of a paradigm shift from symmetric to asymmetric thinking in data analysis and crafting theory", Journal of Business Research, Vol. 66 No. 4, pp. 463-472, available at: https://doi. org/10.1016/j.jbusres.2012.12.021

Wu, H.C. and Li, T. (2017), "A study of experiential quality, perceived value, heritage image, experiential satisfaction, and behavioral intentions for heritage tourists", Journal of Hospitality \& Tourism Research, Vol. 41 No. 8, pp. 904-944.

Yang, Z. and Peterson, R.T. (2004), "Customer perceived value, satisfaction, and loyalty: the role of switching costs”, Psychology \& Marketing, Vol. 21 No. 10, pp. 799-822.

Yoo, B. and Donthu, N. (2001), "Developing a scale to measure the perceived quality of an Internet shopping site (SITEQUAL)", Quarterly Journal of Electronic Commerce, Vol. 2 No. 1, pp. 31-45.

Zeithaml, V.A. (1988), "Consumer perceptions of price, quality, and value: a means-end model and synthesis of evidence", The Journal of Marketing, Vol. 52 No. 3, pp. 2-22. 


\section{About the authors}

Mario Alguacil got his $\mathrm{PhD}$ in Sport Management at University of Valencia. He is Full Professor at the Department of Educational Sciences in Catholic University of Valencia. He writes and presents research results in national and international journals and conferences about brand in sport services. His research interest are brand management and the relationship between the brand and the outcome of sport enterprises. Mario Alguacil is the corresponding author and can be contacted at: mario.alguacil@ucv.es

Juan Núñez-Pomar is Professor of Sports Management at the University of Valencia and holds the position of Sports Manager in the Council of Paterna (Spain). His main areas of research are entrepreneurship, organizational behavior and entrepreneurial orientation.

Carlos Pérez-Campos, $\mathrm{PhD}$ in Sports Management, is Full-Time Professor at the Catholic University of Valencia. His main research areas are the analysis of the quality of service in relation to sporting events as well as the perceived quality and satisfaction of spectators and athletes who are part of sporting events.

Vicente Prado-Gascó holds a PhD in Social Psychology and Organizations at the University of Valencia. Master in Human Resources Management and Organization at the Higher School of Business Management and Marketing (ESIC) in Valencia. He has been Professor and Researcher in national and international public and private universities; he is currently Professor of Social Psychology at the University of Valencia. His areas of interest include the formation of attitudes, interpersonal relations, economic and consumer psychology, emotions and well-being.
Linear models vs QCA

For instructions on how to order reprints of this article, please visit our website: 
5.1.3. Estudio 3. Be congruent and I will be loyal: the case of sport services 



\title{
Be congruent and I will be loyal: the case of sport services
}

\author{
Mario Alguacila, Javier Sánchez-García ${ }^{b}$ and Irena Valantine ${ }^{c}$ \\ aCatholic University of Valencia, Godella, Spain; bUniversitat Jaume I, Castello de la Plana, Spain; 'Lithuanian \\ Sports University, Kaunas, Lithuania
}

\begin{abstract}
This research analyzes the relationship between brand perception of users of a sports service and their levels of loyalty. Data were treated with both SPSS 23 and EQS 6.3, using CFA to confirm reliability and validity and creating a model to be tested. Congruence explain $43 \%$ of credibility and that these two variables explain up to $73 \%$ of trust. Credibility and trust can explain up to $73 \%$ of the attitudes, while attitudes would explain up to $50 \%$ of loyalty. In the case of sports services, brand perception and its relationship with loyalty remain largely unaddressed. For this reason, it is interesting to carry out research on this subject, bringing new evidence to business reality to help managers to understand how to get loyal users and provide a better service, which is good for the sustainability of the service and to better fulfil the social function carried out by sport services.
\end{abstract}

\section{KEYWORDS}

brand management; loyalty; hedonic consumption; sport services; structural equation modeling

\section{Introduction}

In the field of marketing, it is no surprise that brand image work is a fundamental tool for managing a service. Being able to work with the brand image and trying to transmit the image that we want to users is a key in making them perceive the brand in a more positive way, which will make them more willing, more loyal and more likely to recommend the brand, and thus we will attract new clients and retain current ones (Hussain, Al Nasser, and Hussain 2015). However, in the case of sports services, brand perception and its relationship with loyalty remain largely unaddressed; however, in recent times this trend has changed, and today we find increasingly more scientific proposals related to this issue that analyze it from different points of view and with new methodologies. There is also a greater demand for information related to this aspect on the part of managers who have the intention of acquiring knowledge that will enable them to manage their resources more effectively and efficiently. For this reason, it is interesting to carry out research on this subject, with the idea of providing new evidence to continue contributing to the understanding of the relationships between variables in this field, and consequently obtain information applicable to business reality, specifically sports services. 


\section{Theoretical background}

Congruence, which is the starting point of this study, is a fundamental aspect in the analysis of consumer behaviors because users are attracted to products that have a symbolic image most similar to their self-concept (Kwak and Kang 2009) and are, therefore, more consistent with their ways of thinking and acting. The intention is to acquire the symbolic attributes of the brand and thus meet their needs for social approval, self-expression or self-esteem (Pitta and Katsanis 1995). This behavior is related to Festinger's theory of cognitive dissonance (1957), which argues that when we think or act differently from our beliefs we feel psychologically bad. At that point, the body sets in motion mechanisms to eliminate such discrepancies, creating thoughts that in some way justify the behavior or modify our consumer behaviors to return to the coherence or consonance of our acts (dissonant and consonant elements). This type of mechanism is common in the consumer purchasing processes, and it is essential to consider the congruence of the user-brand binomial as a starting point, especially when it has been shown to be an influential element in loyalty (Kressmann et al. 2006).

\section{Brand image}

The concept of brand image has generated problems historically, especially in regard to proposing a consensual definition. However, the research that has been carried out over time has provided information on how the concept was understood in different fields and from different points of view. One of the most widespread and widely accepted definitions is Dowling (1986) that establishes the brand image is a set of meanings that are transmitted to the users and allow the product to be known, described, remembered and related. In more recent definitions, we find those that speak of the brand image as the driving force of both the brand's assets and its performance (Torlak et al. 2014; Zhang 2015), while others such as Dönmez and Türkmen (2018) focus more on the brand image as a set of impressions, whether positive or negative or whether emotional or aesthetic, that a product manages to create in the target audience. Based on this latter definition, we can summarize that the brand image is created from consumer perceptions of a product, thanks to the marketing work done by the brand (Dönmez and Türkmen 2018). Brand perception is therefore a subjective phenomenon. This is a handicap, since getting users' opinions to go in the same direction is complex. Conversely, it is also an advantage since perceptions are susceptible to being influenced, and, if it is done in the right way, to being-modified according to the interests of the brand.

\section{Congruence}

Brand congruence refers to the degree to which users identify with the brand. In other words, describes how products contribute to a consumer's psychological definition of self-concept (Bajac, Palacios, and Minton 2018). This concept measures the fit of the brand and the user, or, in other lines of research, the fit of, for example, the sponsor and the sponsored event from the perception of consumers (Rifon et al. 2004) through the mechanism of brand transfer in sports sponsorships (Alonso-Dos-Santos et al. 2016). This is an important aspect because those brands that think or act in a way that is most similar to what we 
understand should be done can create a link that leads us to have a greater consideration for the brand and a preferential place in our mind when carrying out the purchase process. If there is coherence, consumers will be able to store product information easier because of that connection (Wu 2011). This coherence has been applied within the theory of integrated marketing communication, thus showing its effectiveness on attitudes towards the brand (Navarro-Bailón 2012). As Sirgy (1982), one of the most important authors in the study of congruence, stated, consumers buy products that are in accordance with their own image since they have the desire to be coherent and consistent between what they buy and their own image. This search for coherence is not only a personal matter; we also want the attributes that are associated with the brand to be those that other people associate with us and thus issues of social approval or the expression of who we are come into play (Pitta and Katsanis 1995). In the literature, there are studies that describe this congruence as an element that directly influences the variable of loyalty towards the brand (He and Li 2010; Kressmann et al. 2006), and therefore, we conclude that those users who feel congruent increase both their intentions to pay for a product and their reluctance to accept its sale, which are willingness to pay (WTP) and willingness to accept (WTA), respectively (Thomas, Yeh, and Jewell 2015).

H1. User-brand congruence has a positive and significant influence on the credibility of the brand.

H2. Congruence has a significant influence on brand trust.

\section{Credibility}

The brand credibility perceived by users has been taken into account in numerous studies, but most research has focused on tangible products, and thus overlooked the study of this aspect in services (Bougoure et al. 2016). It is logical to think that those brands that seem more credible to us will generate a better perception in us that will make us consider them more. This credibility can influence beliefs, attitudes and behavior through internalization, accepting the influence of that source on their value structures (Wang and Scheinbaum 2018). In this case, a brand will be considered as credible when the users who receive the information consider it truthful and reliable, and when they positively interpret the historical accumulation of the marketing mix strategies carried out, thus creating a judgment on the brand (Bougoure et al. 2016). This reference to the evaluation of past strategies is related to the vision of Herbig and Milewicz (1995) for whom credibility is based on the promises made by the company, whether they are subsequently fulfilled, and also when the user can use past actions carried out by the brand to predict its future actions. Credibility, therefore, does not correspond to a single moment in time and will not depend on a specific action, but it will depend on the accumulated value of all actions that have been taken over time (Erdem, Swait, and Louviere 2002). Erdem and Swait (1998) have studied this concept of brand credibility a great deal and divide it into two parts; the first part is what they call Trustworthiness, which has to do with consumers' perceptions of the brand's willingness to deliver on its promises, and the second part is what the authors call Expertise, which is more oriented towards the brand's ability to deliver on its promises. In this sense, companies must be very careful, since getting to be credible can involve a great investment of effort, 
time and money, but to stop being credible can be a mistake that causes a reputation crisis. Today, with the rise of social media, the concept of credibility is closely linked to the management of service failures in its work and the management of customer complaints, which reduces abandonment and reduces costs (Sweeney and Swait 2008) while creating and maintaining stable and lasting relationships with customers (Leung, Bougoure, and Miller 2014), which is known as CRM (customer relationship management).

H3. Brand credibility significantly influences brand trust.

H4. Credibility significantly affects users' attitudes towards the brand.

\section{Brand trust}

The concept of brand trust is related to credibility. This relationship is easy to analyze because if we, as consumers, think that a brand is credible, we will feel more confident about it. When those levels of confidence are higher, consumers can have reliable expectations of a brand's intentions (Pauwels-Delassus and Descotes 2013). This aspect of trust has been extensively addressed in the literature, although not so much in relation to sports services, and is understood as a mediator in the relationship between background and marketing performance (Aurier and N'Goala 2010; Vlachos et al. 2009). For Dawar and Pillutla (2000), trust refers to a positive assessment of a brand's reliability. Other authors, such as DelgadoBallester, Munuera-Alemán, and Yagüe-Guillen (2003), state that brand trust appears when the consumer has a sense of security when interacting with a brand, and after perceiving that the brand is reliable, the consumer believes that the actions the brand takes are responsible and that it acts to improve the well-being of its consumers. Trust means that we will be calm as consumers, we will not perceive as many risks as we would with a brand we do not trust, because trust is an assurance which reduces uncertainty so the presence of trust weakens the negative effect of product risk (Carnevale, Loureiro, and Kabadayi 2018) and therefore there is no tension and the user-brand relationship is more comfortable. This will obviously impact users' future intentions since trust has been identified as a clear determinant of loyalty, which in turn would influence brand performance such as brand equity, the market share and the relative price (Chaudhuri and Holbrook 2001; Delgado-Ballester and Munuera-Alemán 2005).

H5. Brand trust has a significant influence on the attitudes towards it.

\section{Attitudes}

Attitudes towards the brand are another aspect that has been a recurring theme in numerous studies related to the brand and the consumer purchasing process over the years. When we talk about attitudes, we are referring to the evaluation that consumers make of a branded product internally (Mitchell and Olson 1981) and overall evaluation of the brand from consumer's perspective (Wang and Scheinbaum 2018), which is a psychological tendency that is expressed when evaluating a certain entity with a certain degree of agreement or disagreement (Eagly and Chaiken 2007). These attitudes are considered important as they are a summary of the assessments that we make as consumers; such a summary, according to Spears and Singh (2004), in addition to being an assessment with relative longevity and 
stability in the consumer's mind (as opposed to emotions that are more ephemeral), can stimulate the behaviors of such consumers. This evaluation provokes a positive or negative disposition towards the brand that is never neutral (Ratneshwar and Shocker 1991) and that will arise as a consequence of the different associations that the user has in his mind about this brand according to his perceptions over time, the information he has received, the recommendations, etc. The means to transfer these symbolic aspects will be promotion and advertising. Furthermore, through the symbolic representation of the product (Saavedra et al. 2008), the brands will try to transmit to consumers their attributes and benefits in order to generate and/or reinforce these attitudes. This strength of attitudes should not be confused with attachment because, although according to Park et al. (2010) the attachment and strength of attitudes have similarities, but they are two constructs with differences, a fundamental one being the difference in motivational power and personal involvement. In addition, they add that attachment has personal and emotional implications that serve as a stronger driving element toward a given behavior, while the strength of the attitudes is a judgment that does not possess such a level of involvement. Attitudes will also have a social component, since the possibility of the existence of social influence will cause users to have different attitudes and intentions, either interactively or noninteractively (Keng et al. 2016).

H6. Brand attitudes will significantly influence the loyalty of users to the sports service.

\section{Loyalty}

Although brand perception and its implications, in particular brand loyalty, are key aspects of business success and management in sports services, they have not yet been widely explored in the scientific literature (Alguacil et al. 2016). Every company, whether it is dedicated to the sales of goods and/or services, aims to ensure that its consumers are loyal, since this ensures that they can continue to make profits, be sustainable and be able to act without the uncertainty (or with less uncertainty) that this number of users will decrease. Once that commitment is made, we will have a more loyal set of customers, which will increase their future intentions regarding the brand, and it will also cause new customers to access the product thanks to positive word of mouth (Sattar, Ali, and Arshad 2014). If we look at the definition of loyalty, we find a classic meaning proposed in Andreassen and Lindestad (1998) who define the concept as the repetition of the purchase process that consumers make. However, this definition only focuses on the repetition of the purchase, and it does not take into account other aspects. It could be, for example, that the repetition of the purchase process occurs because users truly have a disposition and commitment to the brand, but it could also be because it is the easiest and most comfortable option to which they have access or because there are no similar offers at that price. It is in this reflection where other authors have provided insights into the concept of loyalty in order to understand it from different perspectives. An example in this area is the vision of Bloemer and Kasper (1995), who differentiate between what would be real loyalty and false or spurious loyalty. True loyalty would be implying the cognitive aspect, since in it the user carries out a process of evaluation and decision making, and all this leads to a commitment to the brand that is reflected in the repeated purchase behaviors. False or spurious loyalty has to do with a behavioral response that has been carried out over time with a certain level of decision making but is due more to inertia in purchasing than to commitment. Consumer loyalty, 
in the specific case of sports organizations, is desirable for several reasons. It increases intentions to recommend, and it also makes customers less sensitive to price increases, changes of supplier, cross-selling and improves the valuation and corporate image (Calabuig et al. 2014). A previous step in achieving good brand loyalty among users is to create and maintain an appropriate brand image over time with their respective associations (Kayaman and Arasli 2007). That is why the analysis of the brand image is important; it allows us to know which aspects influence others and to what extent so that the actions that we take are effective and require fewer resources. Related to the intent of this article, congruence is a justified starting point for loyalty analysis since consumers do not claim to be loyal to a brand only because it has functional value but also because of the symbolic values that flow from that congruence (Dall'Olmo Riley and De Chernatony 2000; O'Loughlin and Szmigin 2006).

\section{Objectives}

\section{General}

As general objectives, we analyze the brand perceptions of users of a sports service and their levels of loyalty, and we test a model of causal relationships in which the different research hypotheses have been proposed.

\section{Specific}

Our specific objectives are as follows: First, we check whether congruence is a precedent with a significant influence on credibility and trust. Then, we test to determine if credibility and trust are related and whether both are influential in creating positive attitudes towards the brand. Finally, we analyze if attitudes have a significant relationship with users' loyalty to the brand.

\section{Structural model}

In this study, we intend to test a total of six hypotheses. Figure 1 presents the structural model with these hypotheses, the different variables or constructs that make up the model, and the proposed relationships between variables.

\section{Method}

\section{Participants}

This research is a quantitative study in which the opinions of the users are collected through a questionnaire created from the existing bibliography on the subject. As seen in the theoretical framework and later in the model, the variables that have been analyzed are congruence, credibility, trust, attitudes towards the brand and the level of loyalty shown by users. The sample size is 307 users, which corresponds to the users of the facilities that are managed by the Municipal Sports Foundation of the city of Valencia (Spain). This Foundation is the brand of the city council responsible for managing public facilities in the city of Valencia, 


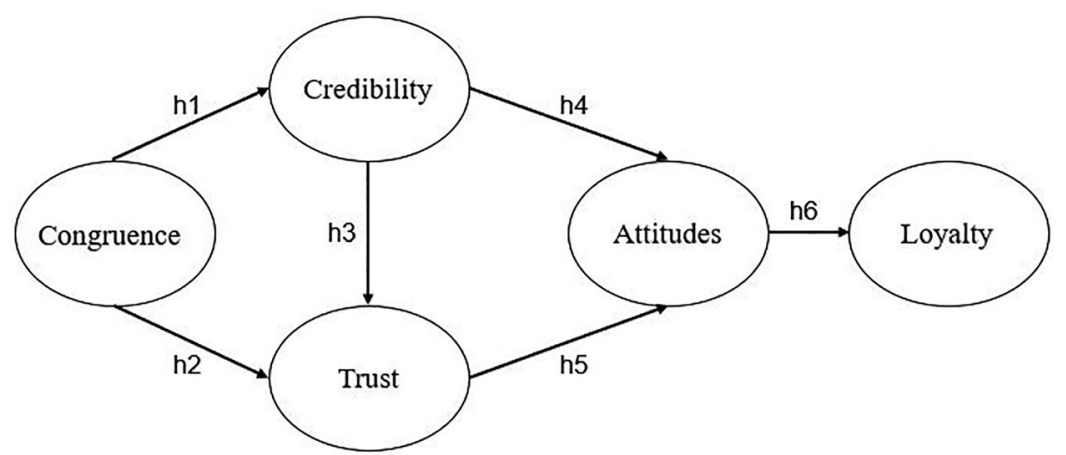

Figure 1. Structural model.

through direct or indirect management. Users pay a fee based on public prices, to access different activities, swimming pool... depending on the facilities of the service they attend. The population is composed of 124 men and 183 women, which corresponds to $40.39 \%$ and $59.60 \%$ of the sample, respectively. The age distribution of respondents is as follows: $24(7.82 \%)$ in the $18-25$ age group, 51 in the $26-35$ group (16.61\%), 89 in the $36-45$ group (28.99\%), 86 in the $46-55$ group (28.01\%) and 67 are over 55 years old (21.82\%). The average age of the population is 44.41 years (SD 12.93). It has been found that users make use of the facilities an average of 3.33 days/week (SD 1.31). While $66.1 \%$ of those surveyed were in the labor force, $12.7 \%$ were unemployed. Retirees represent $11.9 \%$ of the total, and students (without job) represent $4.8 \%$ of the total sample.

\section{Procedure}

A survey was carried out with the intention of testing the model and assessing the relationship between the different factors related to the brand. This survey was conducted with users of facilities belonging to the Municipal Sports Foundation of Valencia through the LimeSurvey application. This tool allows for the creation of online surveys that are then sent via e-mail to the target population. To be able to participate in the study users had to be of legal age and a regular user of the facilities.

\section{Instrument}

To collect the information, a questionnaire was created from the existing bibliography made up of different dimensions related to brand perception and the perception of service performance. For this study, five dimensions have been taken into account: congruence, credibility, trust, attitudes towards the brand and loyalty. The items that constitute the scales have been extracted from the authors and studies that follow.

First, to measure the congruence of the user with the brand, items were obtained from the contribution of Grace and O'Cass (2005): “The image of this service is consistent with my own self-image"; "Using this service reflects who I am"; "People similar to me use this service"; "The kind of person who typically uses this service is very much like me". Second, to measure credibility we drew from the work of Sweeney and Swait (2008): "(Service brand) delivers what it promises"; "XXX' claims about its service are believable"; "XXX has a name 
you can trust"; "XXX reminds me of someone who's competent and knows what he/she is doing"; "XXX doesn't pretend to be something it isn't"; "XXX is at the forefront of using technology to deliver a better service". Third, to measure brand trust, the work of Hur, Kim, and Kim (2014) was taken as a reference: "I trust this brand"; "I rely on this brand"; "This is an honest brand". The fourth construct, which according to the proposed hypotheses would be directly influenced by the two previous concepts, is attitudes towards the brand. To measure this concept, the proposals of Gwinner and Bennet (2008) and Besharat (2010) were used and from which the statements have been extracted. From Gwinner and Bennet the extracted items were the following: "I like the X brand"; "X is a very good brand"; "I have a favorable disposition toward X". On the other hand, the following were extracted from Besharat (2010): "My attitude toward this brand is very positive"; "The use of this brand for this product is adequate"; "I believe this brand relative to other brands is likely to be extremely superior"; "This brand can be very useful". The last section, which is part of the hypotheses and therefore the model, is brand loyalty. To measure it, we included questionnaire items used in the works of Yoo and Donthu (2001), Lee and Leh (2011) and Tong and Hawley (2009) which are aimed at obtaining information about the level of loyalty of the users of a service, which in our case are applied to the field of sports services. The item: "I will not buy other brands if X is available at the store" was extracted from Yoo and Donthu (2001) while the item: "After using the brand, I grow fond of it" was extracted from Lee and Leh (2011). The remaining three items were extracted from Tong and Hawley (2009): "I consider myself to be loyal to X"; "X would be my first choice"; "I would love to recommend X to my friends".

\section{Statistical analysis}

The data were treated with both the SPSS 23 statistical package and the EQS 6.3 structural equations program with the intention of storing all the information collected through the questionnaires and of carrying out the creation and testing of the structural model that would allow us to evaluate our hypotheses. First, once the data was collected, a confirmatory factorial analysis was carried out, which tells us whether the proposed model meets the criteria of reliability and validity. Subsequently, the model was established, and the analyses were carried out to check whether or not the proposed relationships were significant and, if so, to what extent.

\section{Results}

\section{Measurement model}

A confirmatory factor analysis was carried out, and it was found that the instrument used obtained appropriate values in the different indices. Thus, we see how, in the goodness of fit of the model, the value of Satorra-Bentler was 247.02 with 236 degrees of freedom and an associated probability of .30, and thus we can say that the fit of the model is adequate (Bentler 2006). Regarding the value of the indices, we see that they all exceeded the .90 standard established by $\mathrm{Hu}$ and Bentler (1999) as a criterion (NFI=.966, NNFI=.999, $\mathrm{CFI}=.998$, and $\mathrm{IFI}=.998$ ). The RMSEA value was .01 , which was below the criteria of .08 established in the literature (Browne and Cudeck 1993). 
As for the reliability and validity values for each construct that forms part of the analysis, we found the following results: Congruence $(\mathrm{FC}=.92$ and $\mathrm{AVE}=.75)$, Credibility $(\mathrm{FC}=.94$ and $\mathrm{AVE}=.71)$, Trust $(\mathrm{FC}=.96$ and $\mathrm{AVE}=.89)$, Attitudes towards the brand $(\mathrm{FC}=.96$ and $\mathrm{AVE}=.77)$ and loyalty $(\mathrm{FC}=.95$ and $\mathrm{AVE}=.78)$. The composite reliability values were all higher than the .70 standard (Hair et al. 2006), the weights were higher than .60 (Bagozzi and Yi 1988), and the AVE values were higher than .50 (Fornell and Larcker 1981).

Regarding the convergent validity (See Table 1), the factorial loads of all items were above .60 (Hair et al. 2006) and they were all significant with $T$ values higher than 1.96 (Veasna, Wu, and Huang 2013).

Regarding the discriminant validity (See Table 2), according to Fornell and Larcker's (1981) criterion, which considers the square root of the extracted mean variance and Pearson's correlation between each pair of factors, we can say that the values are adequate. The results show that the root AVE of the factors was superior to the correlation of the factors. In addition, the Kline (1998) criterion was also met, which indicates that the correlation between each pair of factors must not exceed the value of .85 , thus ensuring adequate discriminant validity.

\section{Structural model}

A structural equation model was created consisting of a total of five factors: congruence (F1), credibility (F2), trust (F3), attitudes (F4) and loyalty (F5). The hypotheses raised in the study are obtained from the proposed relationships between these variables. Thus, in the results, we find that the congruence of the user with the brand (F1) is an influential element on the credibility (F2) (H1) and on users' trust in that brand (F3) (H2) and that

Table 1. Convergent validity indicators.

\begin{tabular}{lccccccccc}
\hline Construct & Items & $\beta$ & $T$ value & $R 2$ & Construct & Items & $\beta$ & $T$ value & $R 2$ \\
\hline Congruence $(F 1)$ & 1 & .73 & 7.53 & .53 & & 14 & .87 & 4.50 & .76 \\
CR=.92; AVE=.77 & 2 & .81 & 7.94 & .66 & & 15 & .90 & 4.15 & .81 \\
& 3 & .95 & 8.11 & .89 & Attitudes $(F 4)$ & 16 & .93 & 4.64 & .86 \\
& 4 & .95 & 8.03 & .90 & CR=.96, AVE=.80 & 17 & .92 & 4.73 & .85 \\
Credibility (F2) & 5 & .88 & 4.52 & .78 & & 18 & .87 & 4.74 & .76 \\
CR=.94, AVE=.75 & 6 & .93 & 4.49 & .86 & & 19 & .83 & 4.54 & .68 \\
& 7 & .89 & 4.61 & .79 & & 20 & .81 & 4.64 & .65 \\
& 8 & .88 & 4.64 & .77 & & 21 & .85 & 9.80 & .73 \\
& 9 & .69 & 4.32 & .48 & & 22 & .91 & 10.11 & .84 \\
& 10 & .78 & 4.47 & .61 & Loyalty (F5) & 23 & .84 & 9.37 & .71 \\
Trust (F3) & 11 & .91 & 4.47 & .82 & CR=.95, AVE=.80 & 24 & .90 & 9.20 & .81 \\
CR=.96, AVE $=.89$ & 12 & .96 & 5.23 & .92 & & 25 & .89 & 7.71 & .79 \\
& 13 & .96 & 5.23 & .93 & & & & & \\
\hline
\end{tabular}

Table 2. Discriminant validity indicators.

\begin{tabular}{lccccc}
\hline & $\begin{array}{c}\text { Congruence } \\
(\mathrm{F} 1)\end{array}$ & $\begin{array}{c}\text { Credibility } \\
(\mathrm{F} 2)\end{array}$ & $\begin{array}{c}\text { Trust } \\
(\mathrm{F} 3)\end{array}$ & $\begin{array}{c}\text { Attitudes } \\
(\mathrm{F} 4)\end{array}$ & $\begin{array}{c}\text { Loyalty } \\
(\mathrm{F} 5)\end{array}$ \\
\hline Congruence (F1) &. $\mathbf{8 8}$ & & & & \\
Credibility (F2) & .55 &. $\mathbf{8 7}$ & & & \\
Trust (F3) & .62 & .63 & .95 & & \\
Attitudes (F4) & .51 & .64 & .66 & .89 & \\
Loyalty (F5) & .63 & .55 & .68 & .59 &. $\mathbf{9 0}$ \\
\hline Note: The values of the square root of AVE are on the diagonal.
\end{tabular}


credibility is also influential on the level of trust that users of the sports service have (H3). On the other hand, it is also confirmed that both credibility (H4) and trust (H5) have significant influences on the formation of users' attitudes towards the brand (F4). Finally, we can confirm that there is also a significant relationship between users' attitudes towards the brand and their loyalty levels (F5) (H6).

Next, in Figure 2, we illustrate the model with the results obtained after the analysis was completed.

To evaluate the goodness of fit of the model, the data were analyzed and a chi-square value of Satorra-Bentler of 301.04 was obtained with 267 degrees of freedom and an associated probability of .07 (greater than .05); thus, we can say that the fit of the model is adequate (Bentler 2006). The values of the fit indices were also adequate (NFI=.96, $\mathrm{NNFI}=.99, \mathrm{CFI}=.99, \mathrm{CFI}=.99$, and $\mathrm{IFI}=.99)$ since they were all equal to or greater than the .90 criterion ( $\mathrm{Hu}$ and Bentler 1999). For the RMSEA, the value was .03, and thus, below .08 , which is the threshold for whether it is adequate or not (Browne and Cudeck 1993).

In regards to the relations proposed in the structural model (see Table 3), all the relations are significant. Congruence has a significant influence on brand credibility $(\beta=.65, T=13.14)$ which supports H1. Moreover, congruence and credibility affect brand trust $(\beta=.31, T=5.61$; $\beta=.62, T=10.32$ ) with $\mathrm{H} 2$ and $\mathrm{H} 3$ supported. In the relationship between credibility and attitudes (H4) and trust and attitudes (H5), we see that the results are also satisfactory; both of which are supported by values of $\beta=.67, T=8.11$ and $\beta=.22, T=2.85$, respectively. Finally, we see how the hypothesis that attitudes towards the brand significantly influence user loyalty levels (H6) is supported by the higher of the weights recorded, with values of $\beta=.71$

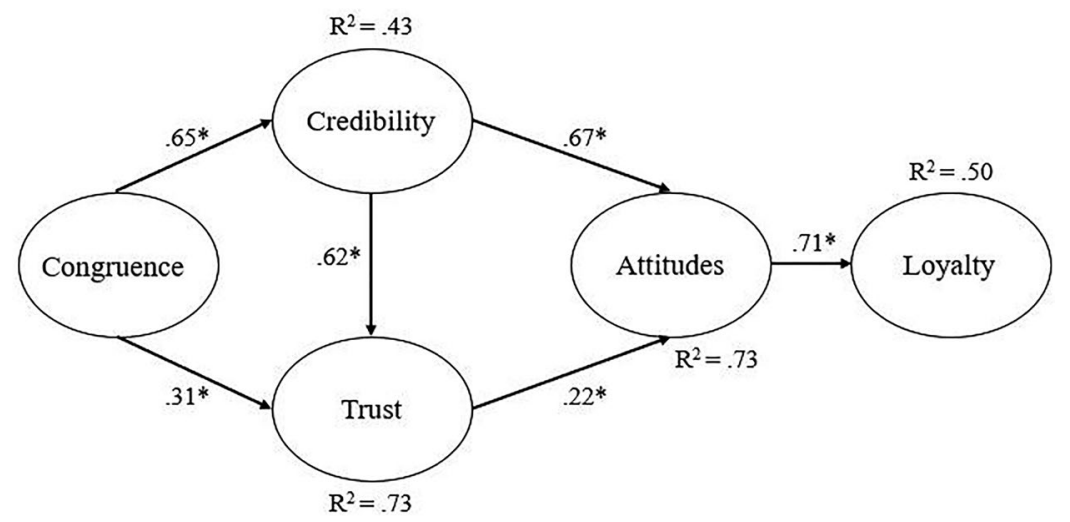

Figure 2. Causal relationship model.

Table 3. Summary of the hypotheses.

\begin{tabular}{|c|c|c|c|}
\hline Hypotheses & $\begin{array}{l}\text { Standardized } \\
\text { coefficients } \\
\text { (beta) }\end{array}$ & $T$ Value & Significance \\
\hline $\mathrm{H} 1$ : Congruence $\triangle$ Credibility & .65 & $13.14^{* *}$ & Supported \\
\hline H2: Congruence $\nabla$ Trust & .31 & $5.61^{* *}$ & Supported \\
\hline H3: Credibility $\bigotimes$ Trust & .62 & $10.32^{* *}$ & Supported \\
\hline H4: Credibility $\otimes$ Attitudes & .67 & $8.11^{* *}$ & Supported \\
\hline H5: Trust $\otimes$ Attitudes & .22 & $2.85^{* *}$ & Supported \\
\hline H6: Attitudes \ Loyalty & .71 & $11.73^{* *}$ & Supported \\
\hline
\end{tabular}


and $T=11.73$. For the predictive capacity of the model, we see that congruence can explain $43 \%$ of the variance in credibility and that these two variables explain up to $73 \%$ of trust, with credibility being the most important factor. On the other hand, credibility and trust can explain up to $73 \%$ of the variance in attitudes, with credibility again being the variable with the greatest weight in the relationship while attitudes towards the brand would explain up to $50 \%$ of the variance in loyalty.

\section{Discussion}

The study of brand perception in services is not a topic that is widely discussed, especially in sports services. This vision is in line with Bougoure et al. (2016) in which they state that although studies of brand perception in services are increasing, most of them are still aimed at the analysis of goods. For the model that is proposed, we wanted to check whether congruence is an element that is significantly related to the credibility and trust towards the brand, since we believe that when a consumer feels identified with a brand, there will be a higher level of credibility and trust. This idea has been proven and thus agrees with Wang (2017) who states that congruence favors credibility (Li, Wang, and Yang 2011) and a sense of security (Olson 2010). This is in line with the concept of trust proposed by DelgadoBallester, Munuera-Alemán, and Yagüe-Guillen (2003).

The concept of credibility is closely related to the perceived risks to users and to their trust. Erdem, Swait, and Louviere (2002) analyzed the negative relationships between the lack of credibility and perceived risk; it is logical to think that if we have higher credibility ratings, the perceived risk will be lower, and we will have a greater sense of brand trust. Consequently, the feeling that we are receiving credible information and perceiving that sense of security when we interact with the brand, which is how brand trust is defined by Delgado-Ballester, Munuera-Alemán, and Yagüe-Guillen (2003), will give us a more positive attitude towards it. This idea is in line with the vision proposed by Yoo and MacInnis (2005) since they explain that when consumers perceive that the information that a brand transmits in its advertising actions is credible, it generates positive attitudes towards it. Likewise, this idea is also in line with Wu and Wang (2011) who state that when the recommendation of a brand comes from a source that we consider credible, the attitudes created towards the brand will also be more positive. This relationship has been significant in our study and in the relationship of trust towards these same attitudes, although with considerably less weight in the latter case. Finally, it is suggested that positive attitudes will make users more loyal to the brand. This union has been analyzed by other authors, such as Seo et al. (2007) and Gwinner and Bennet (2008), and in both cases it was found that when users generate positive attitudes towards the brand, the levels of loyalty increase. The same can be observed in the article by Kim, Morris, and Swait (2008) in which they analyze loyalty based on a model in which credibility generates convictions about the brand and conviction produces positive attitudes that would, in turn, trigger higher levels of loyalty. Finally, we offer an example where the work of the brand is related to loyalty. This is the study by Suh and Youjae (2006), in which the authors relate variables such as satisfaction and attitudes, with the latter coming from the work of advertising actions and corporate image, and thus these attitudes become influential in generating greater loyalty. 


\section{Conclusions, managerial implications and limitations}

As a general conclusion, we can confirm that brand perception truly does influence the loyalty levels of sports service users. More concretely, we can say that the congruence of the user with the brand benefits both credibility and trust, and, in turn, credibility has a significant influence on trust, all of which are a prerequisite for a better attitudinal disposition. This favorable attitudinal disposition would be beneficial to achieving higher levels of user loyalty. With this research, we not only provide information to managers about the perception of their brand but also information about how variables are related that are undoubtedly of interest for the management of sports services and hedonic services in general. In addition, we note the importance of working with the brand instead of other types of actions in the sports field; within this work, the special attention that must be paid to carrying out actions aimed at creating links with users, since this identification is an effective way to improve the levels of loyalty to the service.

In relation to the limitations of the study, we first address the sample size; a larger collection of questionnaires would have allowed us to see results based on a higher percentage of the total number of users, with the results being more generalizable in that sense. Next, we address the limitation of the differentiation of services. If a larger sample had been available, we could have established a separation by facilities to which the users belong and even a differentiation according to the types of management that govern these centers. This could be done either at a general level, by comparing the direct and indirect management, or going deeper into the field of indirect sports management and including the comparison between those services managed by agreement or concession.

Future research would be partly aimed at resolving the limitations mentioned, and therefore we think it would be interesting to make comparisons according to the facilities that the users attend and the type of management that these centers have. Likewise, it would also be appropriate to consider the activities that users do when they go to the sports service and analyze their opinions based on their activities with the intention of extracting relevant information that could reveal certain deficiencies in specific aspects.

\section{References}

Alguacil, M., M. A. Dos Santos, A. Pastor-Barceló, and O. Colino. 2016. “Comparative Qualitative Analysis of Loyalty in Public Sport Services” Revista de psicología del deporte 25 (1): 69-72.

Alonso-Dos-Santos, M., J. Vveinhardt, F. Calabuig, and F. Montoro-Ríos. 2016. "Involvement and Image Transfer in Sports Sponsorship." Engineering Economics 27 (1): 78-89.

Andreassen, T. W., and B. Lindestad. 1998. "Customer Loyalty and Complex Services: The Impact of Corporate Image on Quality, Customer Satisfaction and Loyalty for Customers with Varying Degrees of Service Expertise." International Journal of Service Industry Management 9 (1): 7-23. doi:10.1108/09564239810199923

Aurier, P., and G. N'Goala. 2010. “The Differing and Mediating Roles of Trust and Relationship Commitment in Service Relationship Maintenance and Development." Journal of the Academy of Marketing Science 38 (3): 303-325. doi:10.1007/s11747-009-0163-z

Bagozzi, R. P., and Y. Yi. 1988. "On the Evaluation of Structural Equation Models." Journal of the Academy of Marketing Science 16 (1): 74-94. doi:10.1007/BF02723327

Bajac, H., M. Palacios, and E. Minton. 2018. "Consumer-Brand Congruence and Conspicuousness: An International Comparison.” International Marketing Review 35 (3): 498-517. doi:10.1108/ IMR-12-2016-0225

Bentler, P. M. 2006. EQS 6 Structural Equations Program Manual, ISBN 1-885898-03-7. Encino, CA: Multivariate Software, Inc. 
Besharat, A. 2010. "How Co-Branding Versus Brand Extensions Drive Consumers' Evaluations of New Products: A Brand Equity Approach." Industrial Marketing Management 39 (8): 1240-1249. doi:10.1016/j.indmarman.2010.02.021

Bloemer, J. M., and H. D. Kasper. 1995. "The Complex Relationship between Consumer Satisfaction and Brand Loyalty." Journal of Economic Psychology 16 (2): 311-329. doi:10.1016/01674870(95)00007-B

Bougoure, U. S., R. Russell-Bennett, S. Fazal-E-Hasan, and G. Mortimer. 2016. "The Impact of Service Failure on Brand Credibility." Journal of Retailing and Consumer Services 31:62-71. doi:10.1016/j.jretconser.2016.03.006

Browne, M. W., and R. Cudeck. 1993. "Alternative Ways of Assessing Model Fit.” In Testing Structural Equation Model, edited by K. A. Bollen, and J. S. Long, 136-162. Newbury Park, CA: Sage.

Calabuig, F., J. Núñez-Pomar, V. Prado-Gascó, and V. Añó. 2014. "Effect of Price Increases on Future Intentions of Sport Consumers." Journal of Business Research 67 (5): 729-733. doi:10.1016/j.jbusres.2013.11.035

Carnevale, M., Y. K. Loureiro, and S. Kabadayi. 2018. "Customer Value Creation for Risky Products: The Role of Brand Trust and Trusting Beliefs." Journal of Creating Value 4 (1): 1-21. doi: $10.1177 / 2394964317752731$

Chaudhuri, A., and M. B. Holbrook. 2001. "The Chain of Effects from Brand Trust and Brand Affect to Brand Performance: The Role of Brand Loyalty.” Journal of Marketing 65 (2): 81-93. doi:10.1509/ jmkg.65.2.81.18255

Dall'Olmo Riley, F., and L. De Chernatony. 2000. “The Service Brand as Relationships Builder." British Journal of Management 11 (2): 137-150. doi:10.1111/1467-8551.t01-1-00156

Dawar, N., and M. M. Pillutla. 2000. "Impact of Product-Harm Crises on Brand Equity: The Moderating Role of Consumer Expectations." Journal of Marketing Research 37 (2): 215-226. doi:10.1509/jmkr.37.2.215.18729

Delgado-Ballester, E., and J. Munuera-Alemán. 2005. "Does Brand Trust Matter to Brand Equity?" Journal of Product and Brand Management 14 (3): 187-196.

Delgado-Ballester, E., J. L. Munuera-Alemán, and M. J. Yagüe-Guillen. 2003. "Development and Validation of a Brand Trust Scale." International Journal of Market Research 45 (1): 35-53. doi:10.1177/147078530304500103

Dönmez, Y., and F. Türkmen. 2018. "The Relation Between the Landscape Design and Brand Image in Purchase Preferences of Tourists: The Case of Safranbolu and Nevşehir, in Turkey." Applied Ecology and Environmental Research 16 (1): 629-643. doi:10.15666/aeer/1601_629643

Dowling, G. 1986. “Managing Your Corporate Images.” Industrial Marketing Management 15 (2): 109-115. doi:10.1016/0019-8501(86)90051-9

Eagly, A. H., and S. Chaiken. 2007. “The Advantages of an Inclusive Definition of Attitude." Social Cognition 25 (5): 582-602. doi:10.1521/soco.2007.25.5.582

Erdem, T., and J. Swait. 1998. "Brand Equity as a Signaling Phenomenon." Journal of Consumer Psychology 7 (2): 131-157. doi:10.1207/s15327663jcp0702_02

Erdem, T., J. Swait, and J. Louviere. 2002. "The Impact of Brand Credibility on Consumer Price Sensitivity." International Journal of Research in Marketing 19 (1): 1-19. doi:10.1016/S01678116(01)00048-9

Festinger, L. 1957. A Theory of Cognitive Dissonance. Stanford, CA: Stanford University Press.

Fornell, C., and D. Larcker. 1981. "Evaluating Structural Equation Models with Unobservable Variables and Measurement Error." Journal of Marketing Research 18 (1): 39-50. doi:10.1177/002224378101800104

Grace, D., and A. O’Cass. 2005. "Service Branding: Consumer Verdicts on Service Brands." Journal of Retailing and Consumer Services 12 (2): 125-139. doi:10.1016/j.jretconser.2004.05.002

Gwinner, K., and G. Bennet. 2008. "The Impact of Brand Cohesiveness and Sport Identification on Brand Fit in a Sponsorship Context." Journal of Sport Management 22 (4): 410-426. doi:10.1123/ jsm.22.4.410

Hair, J. F., W. C. Black, B. Babin, R. E. Anderson, and R. L. Tatham. 2006. Multivariate Data Analysis. 6th ed. New Jersey: Prentice Hall. 
He, H., and Y. Li. 2010. "Key Service Drivers for High-Tech Service Brand Equity: The Mediating Role of Overall Service Quality and Perceived Value." Journal of Marketing Management 27 (1-2): 77-99. doi:10.1080/0267257X.2010.495276

Herbig, P., and J. Milewicz. 1995. "The Relationship of Reputation and Credibility to Brand Success." Journal of Consumer Marketing 12 (4): 5-10.

Hu, L. T., and P. M. Bentler. 1999. "Cutoff Criteria for Fit Indexes in Covariance Structure Analysis: Conventional Criteria versus New Alternatives.” Structural Equation Modeling: A Multidisciplinary Journal 6 (1): 1-55. doi:10.1080/10705519909540118

Hur, W. M., M. Kim, and H. Kim. 2014. “The Role of Brand Trust in Male Customers' Relationship to Luxury Brands.” Psychological Reports 114 (2): 609-624. doi:10.2466/01.07.PR0.114k15w8

Hussain, R., A. Al Nasser, and Y. K. Hussain. 2015. "Service Quality and Customer Satisfaction of a UAE-Based Airline: An Empirical Investigation.” Journal of Air Transport Management 42: 167175. doi:10.1016/j.jairtraman.2014.10.001

Kayaman, R., and H. Arasli. 2007. "Customer Based Brand Equity: Evidence from the Hotel Industry." Managing Service Quality: An International Journal 17 (1): 92-109. doi:10.1108/ 09604520710720692

Keng, C. J., W. H. Chang, C. H. Chen, and Y. Y. Chang. 2016. "Mere Virtual Presence with Product Experience Affects Brand Attitude and Purchase Intention." Social Behavior and Personality: An International Journal 44 (3): 431-444. doi:10.2224/sbp.2016.44.3.431

Kim, J., J. D. Morris, and J. Swait. 2008. “Antecedents of True Brand Loyalty." Journal of Advertising 37 (2): 99-117. doi:10.2753/JOA0091-3367370208

Kline, R. B. 1998. "Software Review: Software Programs for Structural Equation Modeling: Amos, EQS, and LISREL." Journal of Psychoeducational Assessment 16 (4): 343-364. doi:10.1177/ 073428299801600407

Kressmann, F., M. J. Sirgy, A. Herrmann, F. Huber, S. Huber, and D. J. Lee. 2006. “Direct and Indirect Effects of Self-Image Congruence on Brand Loyalty." Journal of Business Research 59 (9): 955-964. doi:10.1016/j.jbusres.2006.06.001

Kwak, D. H., and J. H. Kang. 2009. “Symbolic Purchase in Sport: The Roles of Self-Image Congruence and Perceived Quality." Management Decision 47 (1): 85-99. doi:10.1108/00251740910929713

Lee, G. C., and F. C. Y. Leh. 2011. "Dimensions of Customer-Based Brand Equity: A Study on Malaysian Brands." Journal of Marketing Research and Case Studies 2011: 1-10.

Leung, L. C., U. S. Bougoure, and K. W. Miller. 2014. "The Effects of Affective and Utilitarian Brand Relationships on Brand Consideration." Journal of Brand Management 21 (6): 469-484. doi:10.1057/ bm. 2014.15

Li, Y., X. Wang, and Z. Yang. 2011. “The Effects of Corporate-Brand Credibility, Perceived CorporateBrand Origin, and Self-Image Congruence on Purchase Intention: Evidence from China’s Auto Industry." Journal of Global Marketing 24 (1): 58-68. doi:10.1080/08911762.2011.545720

Mitchell, A. A., and J. C. Olson. 1981. "Are Product Attribute Beliefs the Only Mediator of Advertising Effects on Brand Attitude?” Journal of Marketing Research 18 (3): 318-332. doi:10.1177/ 002224378101800306

Navarro-Bailón, M. Á. 2012. "Strategic Consistent Messages in Cross-Tool Campaigns: effects on Brand Image and Brand Attitude." Journal of Marketing Communications 18 (3): 189-202.

O’Loughlin, D., and I. Szmigin. 2006. "Emerging Perspectives on Customer Relationships, Interactions and Loyalty in Irish Retail Financial Services." Journal of Consumer Behaviour 5 (2): 117-129. doi:10.1002/cb.39

Olson, E. L. 2010. "Does Sponsorship Work in the Same Way in Different Sponsorship Contexts?" European Journal of Marketing 44 (1/2): 180-199. doi:10.1108/03090561011008664

Park, C. W., D. J. MacInnis, J. Priester, A. B. Eisingerich, and D. Iacobucci. 2010. "Brand Attachment and Brand Attitude Strength: Conceptual and Empirical Differentiation of Two Critical Brand Equity Drivers." Journal of Marketing 74 (6): 1-17. doi:10.1509/jmkg.74.6.1

Pauwels-Delassus, V., and R. M. Descotes. 2013. "Brand Name Change: Can Trust and Loyalty Be Transferred?” Journal of Brand Management 20 (8): 656-669. doi:10.1057/bm.2013.7

Pitta, D. A., and L. P. Katsanis. 1995. "Understanding Brand Equity for Successful Brand Extension." Journal of Consumer Marketing 12 (4): 51-64. doi:10.1108/07363769510095306 
Ratneshwar, S., and A. D. Shocker. 1991. "Substitution in Use and the Role of Usage Context in Product Category Structures." Journal of Marketing Research 28 (3): 281-295. doi: $10.1177 / 002224379102800303$

Rifon, N. J., S. M. Choi, C. S. Trimble, and H. Li. 2004. "Congruence Effects in Sponsorship: The Mediating Role of Sponsor Credibility and Consumer Attributions of Sponsor Motive." Journal of Advertising 33 (1): 30-42. doi:10.1080/00913367.2004.10639151

Saavedra, J. L., D. Urdaneta, J. L. Pirela, and O. Colmenares. 2008. "Medición de la Personalidad de Marca en el Mercado Automotriz." Visión Gerencial 1 (1): 183-196.

Sattar, S.,. I. Ali, and A. Arshad. 2014. "Customer Loyalty Toward Nokia Brand." Journal of Marketing and Consumer Research 4: 22-28.

Seo, W. J., B. C. Green, Y. K. Ko, S. Lee, and J. Schenewark. 2007. "The Effect of Web Cohesion, Web Commitment and Attitude Toward the Website on Intentions to Use NFL Teams' Websites." Sport Management Review 10 (3): 231-252. doi:10.1016/S1441-3523(07)70013-X

Sirgy, M. J. 1982. "Self-Concept in Consumer Behavior: A Critical Review." Journal of Consumer Research 9 (3): 287-300. doi:10.1086/208924

Spears, N., and S. N. Singh. 2004. "Measuring Attitude Toward the Brand and Purchase Intentions." Journal of Current Issues and Research in Advertising 26 (2): 53-66. doi:10.1080/10641734.2004.1 0505164

Suh, J. C., and Y. Youjae. 2006. "When Brand Attitudes Affect the Customer Satisfaction-Loyalty Relation: The Moderating Role of Product Involvement." Journal of Consumer Psychology 16 (2): 145-155. doi:10.1207/s15327663jcp1602_5

Sweeney, J. C., and S. Swait. 2008. "The Effects of Brand Credibility on Customer Loyalty." Journal of Retailing and Consumer Services 15 (3): 179-193. doi:10.1016/j.jretconser.2007.04.001

Thomas, V. L., M. Yeh, and R. D. Jewell. 2015. "Enhancing Valuation: The Impact of Self-Congruence with a Brand on the Endowment Effect." Journal of Behavioral and Experimental Economics 58:178-185. doi:10.1016/j.socec.2015.05.009

Tong, X., and J. M. Hawley. 2009. "Measuring Customer-Based Brand Equity: Empirical Evidence from the Sportswear Market in China." Journal of Product and Brand Management 18 (4): $262-$ 271. doi:10.1108/10610420910972783

Torlak, O., B. Y. Ozkara, M. A. Tiltay, H. Cengiz, and M. F. Dulger. 2014. “The Effect of Electronic Word of Mouth on Brand Image and Purchase Intention: An Application concerning Cell Phone Brands for Youth Consumers in Turkey." Journal of Marketing Development and Competitiveness 8 (2): 61-68.

Veasna, S., W. Wu, and C. Huang. 2013. “The Impact of Destination Source Credibility: The Mediating Effect of Destination Image.” Tourism Management 36: 511-526. doi:10.1016/j.tourman.2012.09.007

Vlachos, P. A., A. Tsamakos, A. P. Vrechopoulos, and P. K. Avramidis. 2009. "Corporate Social Responsibility: Attributions, Loyalty, and the Mediating Role of Trust." Journal of the Academy of Marketing Science 37 (2): 170-180. doi:10.1007/s11747-008-0117-x

Wang, M. C. H. 2017. "Investigating the Different Congruence Effects on Sports Sponsor Brand Equity." International Journal of Sports Marketing and Sponsorship 18 (2): 196-211. doi:10.2501/ JAR-2017-042

Wang, S. W., and A. C. Scheinbaum. 2018. "Enhancing Brand Credibility via Celebrity Endorsement: Trustworthiness Trumps Attractiveness and Expertise." 58 (1): 16-32. doi:10.2501/JAR-2017-042

Wu, C. C. 2011. "The Impact of Hospital Brand Image on Service Quality, Patient Satisfaction and Loyalty." African Journal of Business Management 5 (12): 4873-4882.

Wu, P. C., and Y. C. Wang. 2011. "The Influences of Electronic Word-of-Mouth Message Appeal and Message Source Credibility on Brand Attitude." Asia Pacific Journal of Marketing and Logistics 23 (4): 448-472. doi:10.1108/13555851111165020

Yoo, B., and N. Donthu. 2001. "Developing a Scale to Measure the Perceived Quality of an Internet Shopping Site (SITEQUAL)." Quarterly Journal of Electronic Commerce 2 (1): 31-45.

Yoo, C., and D. MacInnis. 2005. "The Brand Attitude Formation Process of Emotional and Informational Ads." Journal of Business Research 58 (10): 1397-1406. doi:10.1016/j.jbusres.2005.03.011

Zhang, Y. 2015. "The Impact of Brand Image on Consumer Behavior: A Literature Review." Open Journal of Business and Management 3 (1): 58-62. doi:10.4236/ojbm.2015.31006 



\subsection{Resumen de los resultados}

Una vez presentados los artículos que forman el compendio con el que se elabora la presente tesis doctoral, a continuación, pasaremos a mostrar un resumen de los resultados de los artículos, con el objetivo de presentar de forma resumida cada una de las aportaciones y, con ello, permitir una mejor comprensión de la información. 

5.2.1. Estudio 1. The importance of the services brand in predicting loyalty and word of mouth 

Este primer estudio pretendía comprobar si un modelo propuesto que partía de la calidad percibida, podía ser influyente en la credibilidad y las actitudes que generaban los consumidores, así como ver también en qué medida estas variables influían en la predicción de la lealtad y la recomendación.

En primer lugar, se comprobó mediante un análisis factorial confirmatorio (ver tabla 4) que el modelo de medida tenía un ajuste adecuado $\left(\mathrm{S}-\mathrm{B} \chi^{2}=\right.$ $136.71 ; \mathrm{gl}=94 ; \chi 2 / \mathrm{gl}=1.45 ; \mathrm{NFI}=.94 ; \mathrm{NNFI}=.97 ; \mathrm{CFI}=.98 ; \mathrm{IFI}=.98 ;$ RMSEA = .05) cumpliendo los criterios de fiabilidad y validez, con valores de fiabilidad compuesta entre .88 a .94 , valores de AVE entre .67 y .84, y valores de T entre 2.68 y 10.73 en las hipótesis soportadas.

Tabla 4. Validez convergente del instrumento del estudio 1

\begin{tabular}{|c|c|c|c|c|}
\hline Constructo & Ítems & CR & AVE & R2 \\
\hline \multirow{4}{*}{ Actitudes } & 1 & \multirow{4}{*}{.90} & \multirow{4}{*}{.69} & .689 \\
\hline & 2 & & & .763 \\
\hline & 3 & & & .691 \\
\hline & 4 & & & .619 \\
\hline \multirow{3}{*}{ Credibilidad } & 10 & \multirow{3}{*}{.89} & \multirow{3}{*}{.72} & .798 \\
\hline & 11 & & & .749 \\
\hline & 12 & & & .616 \\
\hline \multirow{3}{*}{ Lealtad } & 46 & \multirow{3}{*}{.86} & \multirow{3}{*}{.67} & .620 \\
\hline & 47 & & & .774 \\
\hline & 48 & & & .617 \\
\hline \multirow{4}{*}{ WOM } & 56 & \multirow{4}{*}{.94} & \multirow{4}{*}{.84} & .810 \\
\hline & 57 & & & .818 \\
\hline & 58 & & & .890 \\
\hline & 59 & & & .585 \\
\hline \multirow{2}{*}{ Calidad } & 61 & \multirow{2}{*}{.88} & \multirow{2}{*}{.70} & .734 \\
\hline & 63 & & & .794 \\
\hline
\end{tabular}

Nota: $\mathrm{CR}=$ fiabilidad compuesta; $\mathrm{AVE}=$ varianza media extraída. 
Dicho modelo de medida planteaba un total de 8 hipótesis (ver figura 1) que constituyen las distintas relaciones entre las variables que se pretenden testar.

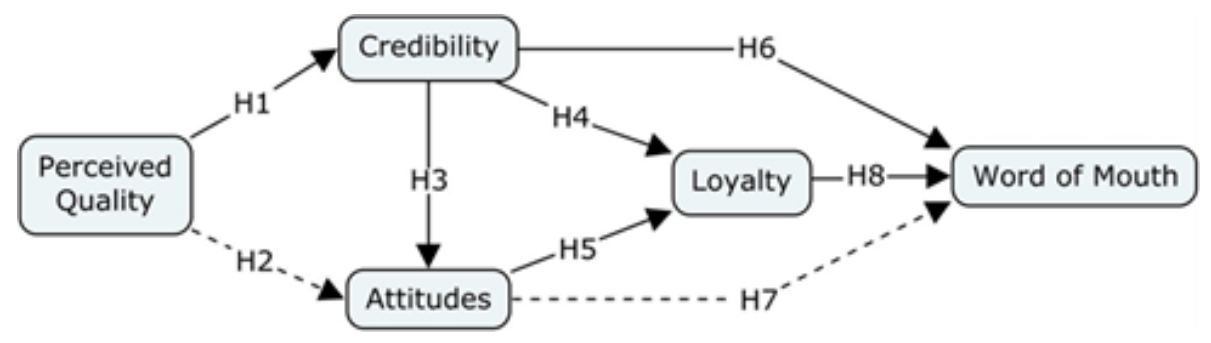

Figura 1. Hipótesis del modelo estructural del estudio 1

Los resultados de las hipótesis (ver tabla 5) indican que la calidad predice significativamente la credibilidad que perciben los usuarios, mientras que no ocurre lo mismo con las actitudes hacia la marca. Por otro lado, se observa que la credibilidad predice las actitudes y la lealtad, y que las actitudes hacen lo propio con la lealtad. Finalmente, se comprueba que la credibilidad influye significativamente en la recomendación, al igual que la lealtad, mientras que la influencia de las actitudes sobre la recomendación no se ha confirmado.

Tabla 5. Resultados de las hipótesis del estudio 1

\begin{tabular}{cccc}
\hline Hipótesis & $\boldsymbol{\beta}$ & $\mathbf{T}$ & Conclusión \\
\hline H1: Calidad-Credibilidad & .82 & $10.73^{* *}$ & Soportada \\
H2: Calidad-Actitud & .21 & 1.87 & No Soportada \\
H3: Credibilidad -Actitud & .63 & $5.41^{* *}$ & Soportada \\
H4: Credibilidad -Lealtad & .34 & $3.09^{* *}$ & Soportada \\
H5: Actitud-Lealtad & .50 & $4.39^{* *}$ & Soportada \\
H6: Credibilidad -WOM & .35 & $2.68^{* *}$ & Soportada \\
H7: Actitud-WOM & -.022 & -0.17 & No Soportada \\
H8: Lealtad-WOM & .55 & $4.88^{* *}$ & Soportada \\
\hline
\end{tabular}

Nota: $\beta=$ coeficiente estandarizado Beta; $\mathrm{T}=$ valor estadístico $\mathrm{T}$. 
5.2.2. Estudio 2. Perceived value, satisfaction and future intentions in sport services: putting congruence and brand trust in the equation. Linear models vs QCA 

El segundo estudio de este compendio, tiene como objetivo, por un lado, mediante modelos de regresión jerárquica, ver si el hecho de introducir las variables de congruencia y confianza en los modelos predictivos del valor, la satisfacción y las intenciones futuras supone que dicha capacidad predictiva mejore significativamente, respecto a los modelos tradicionales que solo ponen en juego las variables de calidad, valor y satisfacción. Posteriormente, mediante el análisis cualitativo comparativo (fsQCA) se quiso determinar la existencia o no de variables necesarias y las combinaciones de variables suficientes que permiten llegar al resultado esperado, para ver si la congruencia y la confianza podían considerarse piezas importantes en la explicación de las variables de interés.

Los resultados (ver tabla 6) han demostrado que el hecho de introducir la congruencia y la confianza en los modelos, mejora significativamente la capacidad predictiva de estos para explicar el valor percibido, la satisfacción y las intenciones futuras $\left(\Delta \mathrm{R}^{2}=.16, \mathrm{p}=.000 ; \Delta \mathrm{R}^{2}=.015\right.$, $\mathrm{p}=.000 ; \Delta \mathrm{R}^{2}=.016, \mathrm{p}=.000$, respectivamente).

En el modelo para el valor percibido se predice de forma significativa la variable $(\mathrm{F}(550.95)=338.45 ; \mathrm{p}<.001)$ hasta un $71 \%$, siendo las variables que más peso muestran, por orden decreciente, la confianza $(\beta=.47$; $\mathrm{p}<.001)$, la congruencia $(\beta=.27 ; \mathrm{p}<.001)$ y la calidad percibida $(\beta=.18$; $\mathrm{p}<.001)$.

En el caso del modelo para la satisfacción $(\mathrm{F}(743.78)=436.54 ; \mathrm{p}<.001)$ el modelo predice hasta el $81 \%$ de su varianza, donde las variables que muestran mayor peso en la relación son la calidad percibida $(\beta=.60$; 
$\mathrm{p}<.001)$, la confianza $(\beta=.17 ; \mathrm{p}<.001)$, la congruencia $(\beta=.11 ; \mathrm{p}<.001)$ y el valor percibido $(\beta=.10 ; \mathrm{p}<.001)$, respectivamente.

En tercer lugar, para el modelo de intenciones futuras $(\mathrm{F}(350.02)=$ 393.53; $\mathrm{p}<.001$ ) el modelo predice de forma significativa hasta el $67 \%$ de su varianza. Las variables que más peso muestran son el valor percibido $(\beta=.33 ; \mathrm{p}<.001)$, la satisfacción $(\beta=.28 ; \mathrm{p}<.001)$, la confianza $(\beta=.22$; $\mathrm{p}<.001)$ y la congruencia $(\beta=.06 ; \mathrm{p}<.05)$, respectivamente.

Tabla 6. Modelo de regresión jerárquica del estudio 2

\begin{tabular}{|c|c|c|c|c|c|c|}
\hline \multirow{2}{*}{$\begin{array}{l}\text { Variable } \\
\text { Predictor }\end{array}$} & \multicolumn{2}{|c|}{$\begin{array}{c}\text { Valor } \\
\text { Percibido }\end{array}$} & \multicolumn{2}{|c|}{ Satisfacción } & \multicolumn{2}{|c|}{$\begin{array}{c}\text { Intenciones } \\
\text { Futuras }\end{array}$} \\
\hline & $\Delta \mathrm{R}^{2}$ & $\beta$ & $\Delta \mathrm{R}^{2}$ & $\beta$ & $\Delta \mathrm{R}^{2}$ & $\beta$ \\
\hline Paso 1 & $.55^{* * *}$ & & $.80^{* * *}$ & & $.66 * * *$ & \\
\hline Calidad Percibida & & $.74 * * *$ & & $.71 * * *$ & & - \\
\hline Valor Percibido & & - & & $.23 * * *$ & & $.46^{* * *}$ \\
\hline Satisfacción & & - & & - & & $.40 * * *$ \\
\hline Paso 2 & $.16^{* *}$ & & $.015^{* * *}$ & & $.016^{* * * *}$ & \\
\hline Calidad Percibida & & $.18 * * *$ & & $.60 * * *$ & & - \\
\hline Valor Percibido & & - & & $.10^{* *}$ & & $.33 * * *$ \\
\hline Satisfacción & & - & & - & & $.28 * * *$ \\
\hline Congruencia & & $.27 * * *$ & & $.11 * * *$ & & $.06 * *$ \\
\hline Confianza & & $.47 * * *$ & & $.17 * * *$ & & $.22 * * *$ \\
\hline Total $\mathrm{R}_{\text {ajustada }}^{2}$ & $.71^{* * *}$ & & $.81^{* * * *}$ & & $.67^{* * * *}$ & \\
\hline
\end{tabular}

Nota: *p<.05; **p<.01; ***p<.001; “-”: no es parte del análisis; $\Delta \mathrm{R}^{2}$ : incremento en $\mathrm{R}^{2}$; $\beta$ : coeficiente estandarizado Beta.

En cuanto al análisis cualitativo comparativo, en el análisis de necesidad (ver tabla 7) se concluye que solo la ausencia de valor percibido puede considerarse como variable necesaria para que se produzca el resultado de 
bajos niveles de satisfacción, ya que es el único caso en el que el valor de consistencia llega a .90 .

Tabla 7. Análisis de necesidad del estudio 2

\begin{tabular}{lccccccccccccc}
\hline & \multicolumn{3}{c}{ PV } & \multicolumn{2}{c}{$\sim$ PV } & \multicolumn{2}{c}{ ST } & \multicolumn{2}{c}{$\sim$ ST } & \multicolumn{3}{c}{ FI } & \multicolumn{2}{c}{$\sim$ FI } \\
\hline & Con & Cov & Con & Cov & Con & Cov & Con & Cov & Con & Cov & Con & Cov \\
\hline CG & .79 & .82 & .43 & .49 & .75 & .87 & .40 & .41 & .77 & .78 & .43 & .50 \\
$\sim$ CG & .51 & .45 & .84 & .82 & .49 & .48 & .87 & .76 & .51 & .44 & .81 & .80 \\
BT & .83 & .85 & .42 & .48 & .77 & .89 & .39 & .39 & .80 & .81 & .43 & .50 \\
$\sim$ BT & .50 & .44 & .87 & .85 & .47 & .47 & .89 & .77 & .50 & .43 & .83 & .83 \\
PQ & .83 & .80 & .47 & .49 & .85 & .91 & .40 & .38 & .82 & .77 & .46 & .49 \\
$\sim$ PQ & .47 & .44 & .81 & .84 & .42 & .45 & .90 & .84 & .46 & .42 & .79 & .84 \\
PV & - & - & - & - & .77 & .87 & .41 & .41 & .82 & .80 & .43 & .49 \\
$\sim$ PV & - & - & - & - & .47 & .48 & .86 & .77 & .48 & .42 & .83 & .84 \\
ST & - & - & - & - & - & - & - & - & .85 & .75 & .48 & .48 \\
$\sim$ ST & - & - & - & - & - & - & - & - & .40 & .40 & .75 & .85 \\
\hline
\end{tabular}

Nota. : ausencia de la condición; Con: consistencia; Cov: cobertura; Condición necesaria Z.90; PV: valor percibido; ST: satisfacción; FI: intenciones futuras; CG: congruencia; BT: confianza en la marca; PQ: calidad percibida.

En el análisis de suficiencia, como se puede apreciar en la tabla 8, las combinaciones que explican en mayor medida altos niveles de valor percibido son altos niveles de calidad percibida y confianza (1), altos niveles de calidad y congruencia (2) y altos niveles de confianza y congruencia (3), mientras que para obtener bajos niveles de valor percibido las combinaciones más relevantes son bajos niveles de confianza y congruencia (1), baja calidad y baja confianza (2) y baja calidad y baja congruencia (3).

Para obtener altos niveles de satisfacción, las interacciones más relevantes son la existencia de alta calidad (1), altos niveles de valor percibido y 
confianza (2) y altos niveles de valor percibido y congruencia (3), mientras que para obtener bajos niveles de satisfacción, las combinaciones que más explican el resultados son bajo valor percibido, baja calidad y baja confianza (1), baja calidad, baja confianza y baja congruencia (2) y bajos niveles de valor, baja calidad y baja congruencia (3).

Finalmente, para explicar altos niveles de intenciones futuras, las interacciones más relevantes son altos niveles de satisfacción, valor percibido y confianza (1), altos niveles de confianza y congruencia (2) y altos niveles de satisfacción, valor percibido y calidad percibida (3) mientras que para conseguir bajos niveles de intenciones futuras, las combinaciones más explicativas son bajos niveles de valor y confianza (1), bajos niveles de valor y congruencia (2) y bajos niveles de calidad percibida y confianza (3). 
5. Resultados y Discusión

Tabla 8. Análisis de suficiencia del estudio 2

\begin{tabular}{|c|c|c|c|c|c|c|c|c|c|c|c|c|c|c|c|c|c|c|}
\hline \multirow[t]{2}{*}{ Frequency cutoff: 1} & \multicolumn{3}{|c|}{$\begin{array}{c}\text { FI } \\
\text { Cutoff: .87 }\end{array}$} & \multicolumn{3}{|c|}{$\begin{array}{c}\sim \mathrm{FI} \\
\text { Cutoff: } .87\end{array}$} & \multicolumn{3}{|c|}{$\begin{array}{c}\text { PV } \\
\text { Cutoff: .87 }\end{array}$} & \multicolumn{3}{|c|}{$\begin{array}{c}\sim \mathrm{PV} \\
\text { Cutoff: } .88\end{array}$} & \multicolumn{3}{|c|}{$\begin{array}{c}\text { ST } \\
\text { Cutoff: } .88\end{array}$} & \multicolumn{3}{|c|}{$\begin{array}{c}\sim \mathrm{ST} \\
\text { Cutoff: .86 }\end{array}$} \\
\hline & 1 & 2 & 3 & 1 & 2 & 3 & 1 & 2 & 3 & 1 & 2 & 3 & 1 & 2 & 3 & 1 & 2 & 3 \\
\hline Satisfacción & - & - & $\bullet$ & - & - & - & & & & & & & & & & & & \\
\hline Valor Percibido & $\bullet$ & - & $\bullet$ & o & ० & - & & & & & & & - & $\bullet$ & $\bullet$ & ○ & - & ○ \\
\hline Calidad Percibida & - & - & $\bullet$ & - & - & ○ & $\bullet$ & $\bullet$ & - & - & ० & ० & $\bullet$ & - & - & ० & ० & ० \\
\hline Confianza & $\bullet$ & $\bullet$ & - & ० & - & ० & $\bullet$ & - & $\bullet$ & ○ & ० & - & - & $\bullet$ & - & ० & ○ & - \\
\hline Congruencia & - & $\bullet$ & - & - & ० & - & - & $\bullet$ & $\bullet$ & $\circ$ & - & ० & - & - & $\bullet$ & - & ○ & ○ \\
\hline Consistency & .89 & .87 & .88 & .89 & .89 & .89 & .89 & .88 & .91 & .91 & .91 & .90 & .91 & .93 & .93 & .91 & .91 & .92 \\
\hline Raw Coverage & .69 & .69 & .71 & .76 & .73 & .73 & .74 & .72 & .71 & .77 & .76 & .73 & .84 & .68 & .66 & .77 & .77 & .76 \\
\hline Unique Coverage & .01 & .02 & .02 & .02 & .01 & .01 & .08 & .05 & .04 & .07 & .06 & .03 & .12 & .02 & .01 & .04 & .04 & .03 \\
\hline Overall Solution Consistency & & & .81 & & & .82 & & & .84 & & & .86 & & & .86 & & & .89 \\
\hline Overall Solution Coverage & & & .84 & & & .88 & & & .84 & & & .86 & & & .91 & & & .84 \\
\hline
\end{tabular}

Nota: $\bullet=$ presencia condición, $\mathrm{o}=$ ausencia condición. Interacciones suficientes son adecuadas, raw coverage entre .65 and $.77 . \quad \sim$ : bajos niveles de la condición. FI: I. futuras; PV: valor percibido; ST: satisfacción Vector esperado I. futuras: 1.1.1.1.1 (0: ausente; 1: presente), Vector esperado para I. futuras: 0.0.0.0.0. Vector esperado para valor percibido: 0.1.1.1 (0: ausente; 1: presente), Vector esperado para valor percibido: 1.0.0.0. Vector esperado para satisfacción: 1.1.1.1. (0: ausente; 1: presente), Vector esperado para satisfacción: 0.0.0.0. Usando el formato de Fiss (2011). 
Una vez conocidos los resultados, a continuación, se muestran los resultados de las hipótesis del estudio 2 (ver tabla 9), donde podemos ver que, de las tres hipótesis, las dos primeras quedan soportadas, mientras que la tercera solo queda soportada parcialmente, ya que la congruencia y la confianza aparecen como una combinación para conseguir las intenciones futuras y el valor percibido, pero no ocurre lo mismo con la satisfacción.

Tabla 9. Resultados de las hipótesis del estudio 2

\begin{tabular}{ccc}
\hline & Hipótesis & Conclusión \\
\hline H1 & $\begin{array}{c}\text { Las variables relacionadas con la marca predicen } \\
\text { significativamente el valor percibido, la satisfacción y las } \\
\text { intenciones futuras de la misma forma que las variables } \\
\text { clásicas relacionadas con el rendimiento del servicio }\end{array}$ & Soportada \\
\hline \multirow{3}{*}{$\begin{array}{c}\text { Las variables relacionadas con la marca tendrán un mayor } \\
\text { peso predictivo en algunas predicciones que las variables } \\
\text { de servicio que se han analizado principalmente en la } \\
\text { literatura }\end{array}$} & Soportada \\
\hline H3 & $\begin{array}{c}\text { La congruencia y la confianza estarán presentes en las } \\
\text { combinaciones que permiten obtener los resultados } \\
\text { esperados }\end{array}$ & Soportada \\
\hline
\end{tabular}


5.2.3. Estudio 3. Be congruent and I will be loyal: the case of sport services 

El tercer y último estudio, propone analizar un modelo estructural de cuyas relaciones surgen 6 hipótesis a testar (ver figura 2). Dichas hipótesis plantean que, partiendo de la congruencia entre la marca y lo que los consumidores opinan de ellos mismos, será posible predecir de forma significativa la credibilidad que perciben de la marca, así como la confianza que sienten hacia ella. Posteriormente, se plantea que esa credibilidad y confianza generadas, serán capaces de explicar las actitudes que generan los consumidores hacia la marca. para, finalmente, a partir de ellas predecir de forma significativa la lealtad que tendrán hacia la marca.

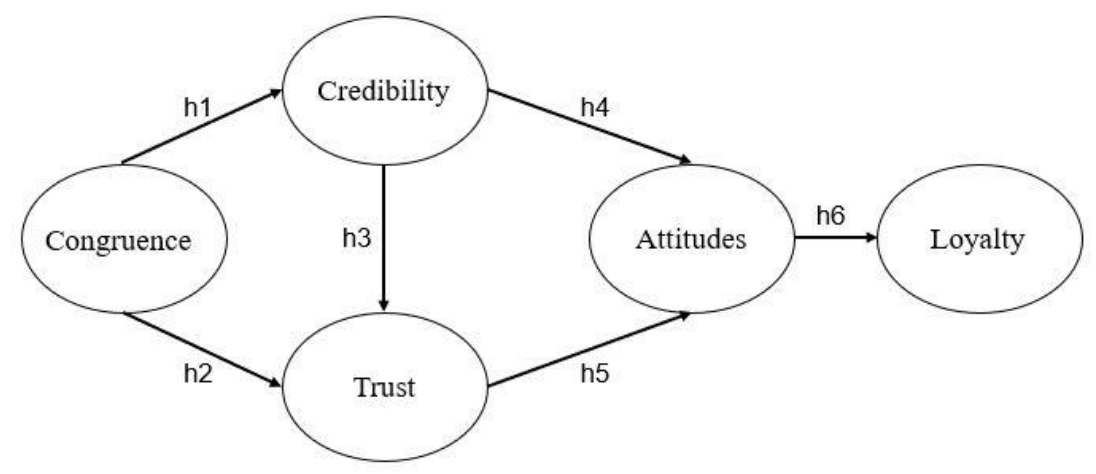

Figura 2. Modelo estructural del estudio 3

Los resultados obtenidos en el análisis del modelo de medida, que se muestran en la tabla 10, indican que el modelo tiene un ajuste adecuado (S$\mathrm{B} \chi 2=247.02 ; \mathrm{gl}=236 ; \chi 2 / \mathrm{gl}=1.05 ; \mathrm{NFI}=.97 ; \mathrm{NNFI}=1 ; \mathrm{CFI}=1 ; \mathrm{IFI}=$ $1 ;$ RMSEA = .01), con valores de fiabilidad compuesta que oscilan entre .92 y .96 y valores de AVE entre .75 y .89. En cuanto a la validez convergente, los pesos factoriales de los ítems superaron el .60 y los valores de $\mathrm{T}$ estuvieron entre 4.15 y 10.11. 
Tabla 10. Indicadores de validez convergente en el estudio 3

\begin{tabular}{ccccclcccc}
\hline Constructo & Ítem & $\boldsymbol{\beta}$ & $\mathbf{T}$ & $\mathbf{R}^{\mathbf{2}}$ & Constructo & Ítem & $\boldsymbol{\beta}$ & $\mathbf{T}$ & $\mathbf{R}^{\mathbf{2}}$ \\
\hline Congruencia & 1 & .73 & 7.53 & .53 & & 14 & .87 & 4.50 & .76 \\
CR=.92; & 2 & .81 & 7.94 & .66 & & 15 & .90 & 4.15 & .81 \\
AVE=.77 & 3 & .95 & 8.11 & .89 & Actitudes & 16 & .93 & 4.64 & .86 \\
& 4 & .95 & 8.03 & .90 & CR=.96, & 17 & .92 & 4.73 & .85 \\
& 5 & .88 & 4.52 & .78 & AVE $=.80$ & 18 & .87 & 4.74 & .76 \\
Credibilidad & 6 & .93 & 4.49 & .86 & & 19 & .83 & 4.54 & .68 \\
CR=.94, & 7 & .89 & 4.61 & .79 & & 20 & .81 & 4.64 & .65 \\
AVE=.75 & 8 & .88 & 4.64 & .77 & & 21 & .85 & 9.80 & .73 \\
& 9 & .69 & 4.32 & .48 & & 22 & .91 & 10.11 & .84 \\
& 10 & .78 & 4.47 & .61 & Lealtad & 23 & .84 & 9.37 & .71 \\
Confianza & 11 & .91 & 4.47 & .82 & CR $=.95$, & 24 & .90 & 9.20 & .81 \\
CR=.96, & 12 & .96 & 5.23 & .92 & AVE $=.80$ & 25 & .89 & 7.71 & .79 \\
AVE=.89 & 13 & .96 & 5.23 & .93 & & & & & \\
\hline
\end{tabular}

Nota: $\mathrm{CR}=$ fiabilidad compuesta; $\mathrm{AVE}=$ varianza media extraída.

En cuanto a la validez discriminante (ver tabla 11) podemos afirmar que se cumplen los criterios de que la raíz de AVE sea superior la correlación de los factores, y que dicha correlación no supere el valor de .85 .

Tabla 11. Validez discriminante en el estudio 3

\begin{tabular}{cccccc}
\hline Variable & Congruencia & Credibilidad & Confianza & Actitudes & Lealtad \\
\hline Congruencia & $\mathbf{. 8 8}$ & & & & \\
Credibilidad & .55 & .87 & & & \\
Confianza & .62 & .63 & .95 & & \\
Actitudes & .51 & .64 & .66 & $\mathbf{. 8 9}$ & \\
Lealtad & .63 & .55 & .68 & .59 & $\mathbf{. 0 0}$ \\
\hline
\end{tabular}

Nota: En la diagonal los valores de la raíz cuadrada de la varianza media extraída.

Una vez analizadas las consideraciones previamente comentadas, se obtienen los resultados del modelo de relaciones causales (ver figura 3). 
Dichos resultados, nos indican que el ajuste del modelo estructural es adecuado $(\mathrm{S}-\mathrm{B} \chi 2=301.04 ; \mathrm{gl}=267 ; \chi 2 / \mathrm{gl}=1.13 ; \mathrm{NFI}=.96 ; \mathrm{NNFI}=.99$; $\mathrm{CFI}=.99 ; \mathrm{IFI}=.99 ; \mathrm{RMSEA}=.03)$ y que todas las relaciones propuestas han mostrado ser significativas.

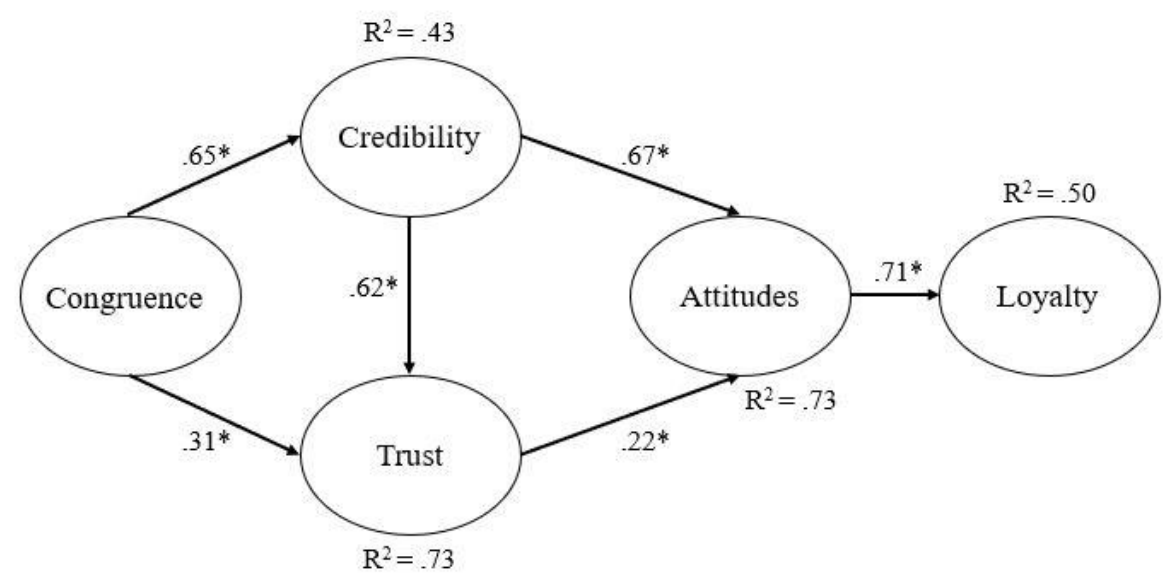

Figura 3. Modelo de relaciones causales del estudio 3

Por tanto, en la resolución de las hipótesis planteadas en el estudio (ver tabla 12) podemos confirmar, en primer lugar, que la congruencia con la marca predice de forma significativa hasta el $43 \%$ de la varianza de la credibilidad que perciben los usuarios de ella, y que, partiendo de la congruencia y la credibilidad, podemos llegar a explicar a nivel teórico hasta el $73 \%$ de la confianza que generan los consumidores. Por otro lado, se confirma también que la credibilidad y la confianza influyen significativamente en la predicción de las actitudes que generan los usuarios hacia la marca, explicando hasta un $73 \%$ de su varianza, y que, finalmente, estas actitudes pueden explicar a nivel teórico hasta un 50\% de la lealtad que tendrán los consumidores. 
Tabla 12. Resultados de las hipótesis del estudio 3

\begin{tabular}{lccc}
\hline \multicolumn{1}{c}{ Hipótesis } & B & T & Significación \\
\hline H1: Congruencia Credibilidad & .65 & $13.14^{* *}$ & Soportada \\
H2: Congruencia-Confianza & .31 & $5.61^{* *}$ & Soportada \\
H3: Credibilidad-Confianza & .62 & $10.32^{* *}$ & Soportada \\
H4: Credibilidad-Actitudes & .67 & $8.11^{* *}$ & Soportada \\
H5: Confianza-Actitudes & .22 & $2.85^{* *}$ & Soportada \\
H6: Actitudes-Lealtad & .71 & $11.73^{* *}$ & Soportada \\
\hline
\end{tabular}

Nota: $\beta=$ coeficiente estandarizado beta; $\mathrm{T}=$ valor estadístico $\mathrm{T}$. 


\subsection{Discusión}

En cuanto a la discusión de los resultados, se realizará un repaso por las distintas variables que forman parte de los estudios propuestos y que, de la misma manera, han constituido el marco teórico de la presente tesis doctoral. Una vez desarrollada y conocida la conceptualización de cada uno de los aspectos que se ha realizado al inicio de este compendio, ya se pueden intuir ciertas relaciones entre variables que podrían tener sentido y resultar influyentes para su mejora. A continuación, a pesar de que en los propios artículos que forman el compendio se lleva a cabo la discusión de los resultados, reforzaremos a nivel general esa explicación de las relaciones que se intuyen gracias a las evidencias científicas del ámbito del marketing. Estas evidencias han ido configurando la red de relaciones entre las variables de marca, así como entre las variables de marca y las de servicio, lo que permite establecer la estructura de cómo entendemos hoy en día los procesos de compra y del comportamiento del consumidor.

En primer lugar, se ha comentado el concepto de credibilidad. Cuando hacemos uso de una marca y tenemos una experiencia satisfactoria con ella, ya sea a nivel presencial o virtual, aumentan la credibilidad que percibimos de la marca y también las probabilidades de que sean mayores nuestras intenciones de compra (Jeng, 2016) y de que la recomendemos a otras personas (Dwivedia et al., 2018). El hecho de conseguir generar credibilidad, también es positivo para la mejora de la equidad de marca (Aaker \& Joachimsthaler, 2000), aunque no existen muchos estudios que analicen el efecto mediador de la credibilidad en este sentido, la 
credibilidad ha demostrado ser influyente en la formación y mejorar de la autenticidad de la marca, así como de la anteriormente comentada equidad de marca (Del Barrio-García \& Prados-Peña, 2019).

Este concepto de credibilidad tiene una relación lógica con el concepto de confianza en la marca y del riesgo percibido, ya que, donde exista una baja credibilidad percibida aumentará la sensación de riesgo por parte de los consumidores (Erdem et al., 2002) y como resulta lógico, lo que interesa es aumentar la confianza en la marca para disminuir ese riesgo percibido (Frasquet et al., 2017). Siguiendo con el papel de la confianza en relación a otras variables, este aspecto ha sido relacionado con variables como la credibilidad de la publicidad y la credibilidad corporativa (Hussain et al., 2020) con variables tradicionales en el entorno de los servicios deportivos como son la calidad percibida, el valor percibido y la satisfacción (Kim \& Peterson, 2017) como mediador entre la responsabilidad social corporativa y la lealtad (Khan \& Fatma, 2019) y entre la satisfacción con el servicio y la lealtad de los usuarios hacia él (Choi \& La, 2013) así como entre la calidad percibida y la satisfacción (Gummerus et al., 2004; Muskat et al., 2019).

En cuanto a la lealtad, ya hemos visto en qué forma desde la credibilidad y la confianza en la marca podemos contribuir a llegar hacia ella, quedando claro que existen relaciones influyentes entre variables como la credibilidad, la lealtad, la satisfacción y la recomendación (An et al., 2019; Sweeney \& Swait, 2008). El hecho de tener clientes leales, lógicamente tiene un interés para la sostenibilidad de la empresa, pero además también tiene otros beneficios, como la menor sensibilidad a los aumentos de precio 
(Kotler \& Keller, 2006; Pandey et al., 2019) o la intención de pagar precios más altos por una marca y no por otra cuando ambas ofrecen beneficios similares (Chaudhuri \& Holbrook, 2001). Para conseguir generar mejores niveles de lealtad, la congruencia también es un aspecto que debemos tener en cuenta, ya que cuando como consumidores, vemos a una marca más similar a nosotros y sentimos que tenemos un buen ajuste con ella, aumentamos nuestro compromiso con ella (Karampela et al., 2018) y la lealtad hacia esa marca será más probable (Japutra et al., 2019; Nam et al., 2011) ya que solemos utilizar las marcas que encajan con nosotros como vehículo para mostrar nuestro autoconcepto (Ekinci et al., 2013). Además, también serán importantes las asociaciones de la marca, ya que, si somos capaces de trabajar correctamente y mantener una adecuada imagen de marca con las asociaciones deseadas, podremos facilitar que pueda producirse esa generación de mejores niveles de lealtad (Jin, Yoon, \& Lee, 2019; Kayaman \& Arasli, 2007).

Si tenemos clientes satisfechos con el servicio, la probabilidad de que sean leales es más alta y, del mismo modo, si tenemos usuarios con unos niveles de lealtad elevados, será más probable que estos puedan recomendar el servicio (Wang, Hernández, \& Minor, 2010) ya que la recomendación está directamente influenciada por los niveles de lealtad de las personas que realizan dicha recomendación (Kumar \& Shah, 2004).

La mejora de la recomendación vendrá, por tanto, determinada por la satisfacción de los usuarios (algo que resulta lógico, por otra parte) y uno de los aspectos a analizar en los estudios sobre imagen de marca que se están realizando en el contexto deportivo, es conocer cómo se puede 
alcanzar esa lealtad, sin recurrir a las variables clásicas de servicio sino de qué manera se puede llegar a esa satisfacción a partir de las variables relacionadas con la marca. En este sentido, vemos como, por ejemplo, si conseguimos generar credibilidad, mejorarán los niveles de satisfacción con la marca y eso hará que aumente también la recomendación (Sweeney \& Swait, 2008). El hecho de recibir recomendaciones positivas sobre una marca, hace que, incluso sin conocer mucho de ella, podamos crear expectativas positivas sobre el servicio que ofrece dicha marca (See-To \& Ho, 2014) lo que automáticamente hará que generemos mayor confianza hacia la marca de la que habríamos generado a priori sobre ella (Kim, Ferrin, \& Rao, 2008) y también que percibamos que esa marca es más creíble (Dwivedia et al., 2018). Al mismo tiempo, percibir una marca como más creíble, hace que los usuarios procesen dicha credibilidad y la asocien con mayores niveles de calidad de la marca (Erdem et al., 2002) por lo que el hecho de conseguir ser creíbles afectará a la calidad percibida de nuestra marca.

Con el avance tecnológico, como el crecimiento del social media y del comercio online, lógicamente los contextos y comportamientos de compra han cambiado. Esos nuevos escenarios que se están produciendo, provocan nuevos retos que se deben ir analizando, puesto que, aunque ya hay mucha teoría generada en torno al comportamiento del consumidor, estas nuevas relaciones que se establecen entre marcas y consumidores y las peculiaridades de los entornos en los que operan, requieren de análisis para comprobar si los patrones estudiados se mantienen o si muestran diferencias, lo que implicaría la necesidad de enfocar de forma diferente lo 
que hemos conocido hasta ahora. El social media ha crecido rápidamente en los últimos años, un elemento al que las personas le conceden cada vez más importancia en su vida diaria (Alalwan et al., 2017) lo que aumenta la frecuencia de las interacciones que se producen en el entorno online tanto a nivel profesional como personal (Baccarella et al., 2018) y lógicamente, unido a esto, se ha producido una relación más fluida entre consumidores y marcas, lo que supone una mayor exigencia para la gestión de customer relationship management (CRM). Este crecimiento, según López-Carril, Villamón y Añó (2019) se debe principalmente al creciente acceso de la población a tecnologías que permiten su funcionamiento, ya que se ha popularizado el uso de smartphones, tabletas, ordenadores...beneficiando a su expansión, siendo hoy en día millones de usuarios en este entorno virtual, algunos de ellos, usuarios que desde su nacimiento han convivido con estas tecnologías, lo que les convierte en un perfil de consumidor distinto a lo que hemos tenido hasta el momento, lo que está suscitando el interés de los investigadores para analizar las percepciones relacionadas con la marca a nivel online (Quan et al., 2020) así como las comunidades virtuales que se van creando en ese entorno del social media (Carlson et al., 2019). Esto hace que surjan este tipo de investigaciones también en el ámbito deportivo, donde encontramos aportaciones como la de $\mathrm{Na}$ et al. (2020), en la que se analiza cómo el contenido que se transmite a través del social media puede afectar a las percepciones de los consumidores y a su apego con la marca. 



\section{CAPÍTULO VI. CONCLUSIONES}





\section{CONCLUSIONES}

A continuación, se muestran las principales conclusiones de los estudios realizados:

\subsection{Estudio 1. The importance of the services brand in predicting loyalty and word of mouth}

En el primer estudio, los resultados del modelo de ecuaciones estructurales propuesto indican, en primer lugar, que la calidad percibida por los usuarios del servicio influye significativamente en la credibilidad que estos le otorgan a la marca, pero no ocurre lo mismo con las actitudes que generan dichos usuarios, donde vemos que la calidad percibida no las predice significativamente. También se confirma que la credibilidad que perciben los usuarios les influye de manera directa en las actitudes que generan hacia la marca, afectando ambas a la mejora de la lealtad hacia la marca de los usuarios de los servicios deportivos analizados. Por otro lado, se confirma que la credibilidad influye en la lealtad, así como en la recomendación, mientras que las actitudes que tienen los usuarios solo influyen de forma directa sobre la lealtad. Finalmente, vemos que la lealtad influye de manera significativa en la recomendación que harán del servicio los usuarios. 


\subsection{Estudio 2. Perceived value, satisfaction and future intentions in sport services: putting congruence and brand trust in the equation. Linear models vs QCA}

En el segundo estudio, en el que se realiza un contraste entre la metodología lineal y la metodología de análisis cualitativo comparativo, se extraen conclusiones relacionadas con cada una de ellas. En cuanto al análisis de los modelos de regresión jerárquica (HRM), se demuestra que debemos prestar atención a las variables relacionadas con la marca, ya que como se ha comprobado en este análisis, la congruencia y la confianza predicen de manera significativa el valor percibido, la satisfacción y las intenciones futuras de los usuarios de los servicios deportivos, situándose en el caso de la predicción del valor percibido, por encima de la calidad percibida, que ha sido considerado históricamente su mejor antecedente. Además, la inclusión de las variables de marca hace que los modelos mejoren significativamente la capacidad de predicción de las variables de interés, especialmente en el caso del valor percibido. En cuanto al modelo de análisis cualitativo comparativo, la confianza y la congruencia han mostrado ser variables suficientes para obtener altos valores de intenciones futuras y de valor percibido, de la misma forma que la ausencia de ambas permite explicar bajos valores de valor percibido, mientras que en la satisfacción no ocurre lo mismo. Además de esto, la congruencia y la confianza sí que están presentes dentro de las combinaciones que consiguen explicar más el resultado esperado, por lo que además de poder explicar 
por sí solas algunos resultados, también han mostrado ser importantes en las combinaciones que más explican el valor percibido, la satisfacción y las intenciones futuras. Por tanto, este estudio comparado confirma la importancia que tienen las variables relacionadas con la marca en la predicción de las variables clásicas de rendimiento del servicio, ya que se ha demostrado, por un lado, que gracias a ellas los modelos predictivos propuestos mejoran significativamente, y por otro, que dichas variables de marca forman parte de las combinaciones que más explican las variables de interés, siendo además suficientes para explicar por sí solas algunos de los resultados de interés, por lo que incluir la congruencia y la confianza como variables influyentes dentro de los análisis es positivo. 


\subsection{Estudio 3. Be congruent and I will be loyal: the case of sport services.}

En el tercer estudio, como conclusión general, podemos decir que se confirma que las variables de percepción de marca tienen una influencia significativa en la lealtad de los usuarios. Si atendemos de manera específica a las relaciones que se han establecido para contrastar, vemos que, en primer lugar, la congruencia del usuario con la marca es un aspecto que tiene una influencia significativa sobre la credibilidad que perciben los usuarios, así como sobre la confianza que generan hacia la marca, de la misma forma que la credibilidad ha mostrado ser influyente en la confianza que generan los usuarios del servicio. Posteriormente, se ha comprobado que tanto la credibilidad percibida por los usuarios como la confianza, predicen de forma significativa las actitudes hacia la marca, siendo mayor el peso explicativo de la credibilidad que el de la confianza. Finalmente, las actitudes hacia la marca demuestran ser influyentes para explicar de forma significativa la lealtad de los usuarios hacia la marca. 


\section{CAPÍTULO VII. IMPLICACIONES, LIMITACIONES Y LÍNEAS FUTURAS DE INVESTIGACIÓN}



7. Implicaciones, limitaciones y líneas futuras

\section{IMPLICACIONES, LIMITACIONES Y LÍNEAS FUTURAS DE INVESTIGACIÓN}

\subsection{Implicaciones para el marketing y la gestión deportiva}

Las investigaciones que forman el presente compendio de publicaciones, suponen una contribución a la literatura científica sobre la percepción de marca en servicios deportivos, una temática prácticamente inexistente pero que tiene un amplio potencial, a tenor del crecimiento continuo del sector deportivo y de las particularidades de dicho sector, debido a los valores inherentes al deporte, en comparación con otras áreas de servicios. Los resultados extraídos confirman la importancia de las variables relacionadas con la marca y, por tanto, la necesidad de trabajar este aspecto para poder entender los procesos relacionados con los comportamientos de los consumidores, contribuyendo a explicar en mayor medida aspectos que son fundamentales para el éxito y la sostenibilidad del servicio. Por otro lado, la variedad de metodologías propuesta, supone una aproximación novedosa a las temáticas de análisis, permitiendo estudiar las relaciones con instrumentos más exhaustivos y sirviendo para entender desde distintos enfoques los fenómenos estudiados. Los gestores deportivos y los gestores de marketing deportivo, tienen un interés creciente en este tipo de información, ya que son cada vez más conscientes de lo valiosa que puede resultar para entender los procesos que se producen en las percepciones de los consumidores del contexto deportivo y como eso puede afectar a su comportamiento. Por tanto, este tipo de estudios dan respuesta a las 
inquietudes que se generan en el ámbito empresarial, aportando esa transferencia de conocimiento que da sentido a la investigación científica y, al mismo tiempo, contribuyendo al crecimiento del ámbito científico en cuestión, aportando herramientas a los gestores para que puedan planificar sus estrategias y acciones de forma más adecuada. Esto no solo repercutirá en que los gestores puedan tomar mejores decisiones y utilizar menos recursos, sino que también beneficiará a los consumidores, ya que recibirán servicios más adaptados a sus necesidades y preferencias y, por tanto, podrán tener una mayor sensación de que el servicio les aporta aquello que necesitan.

\subsection{Limitaciones y líneas futuras de investigación}

En cuanto a las limitaciones que podemos encontrar dentro de los estudios realizados, probablemente la mayor de ellas sea que no se ha realizado una comparativa amplia entre tipos de servicios. Dicha comparativa sería útil para ver si los resultados que ofrecen los modelos varían significativamente en función de, por ejemplo, la titularidad del servicio, el nivel socioeconómico de los usuarios o el tiempo de permanencia en el servicio. También resultaría interesante tener en cuenta el tipo de gestión que llevan a cabo los centros deportivos, qué tipo de posicionamiento tienen en cuanto a precio o qué tipo de actividades ofertan. Todo ello podría aportar información más detallada que nos permitiese encontrar estrategias de mejora en cada uno de los grupos o realidades. 
7. Implicaciones, limitaciones y líneas futuras

En este sentido, investigaciones futuras que analicen los aspectos anteriormente comentados, podrían aportar visiones diferentes de cómo se percibe la marca en función de ellos, comprobando si los modelos planteados ofrecen resultados diferentes, lo que podría contribuir a la creación de estrategias de marketing más concretas. Finalmente, resultaría interesante plantear este tipo de investigaciones de forma transnacional, comparando diferentes contextos y observando si las relaciones que se plantean y que son capaces de explicar variables interesantes en un contexto deportivo concreto, lo hacen también en contextos diferentes. 

CAPÍTULO VIII. REFERENCIAS 



\section{REFERENCIAS}

\subsection{Referencias generales}

Abosag, I., Ramadan, Z. B., Baker, T., \& Jin, Z. (2019). Customers' need for uniqueness theory versus brand congruence theory: The impact on satisfaction with social network sites. Journal of Business Research (in press).

Abrams, D., \& Hogg, M. A. (1988). Comments on the motivational status of self-esteem in social identity and intergroup discrimination. European journal of social psychology, 18(4), 317-334.

Alalwan, A. A., Rana, N. P., Dwivedi, Y. K., \& Algharabat, R. (2017). Social media in marketing: A review and analysis of the existing literature. Telematics and Informatics, 34(7), 1177-1190. doi:10.1016/j.tele.2017.05.008

Alguacil, M., Crespo-Hervás, J., \& Pérez-Campos, C. (2020). Análisis sociodemográfico de la percepción de marca en un servicio deportivo público: del target al buyer persona. Retos, 37(37), 139146.

Alnawas, I., \& Aburub, F. (2016). The effect of benefits generated from interacting with branded mobile apps on consumer satisfaction and purchase intentions. Journal of Retailing and Consumer Services, 31, 313-322. 
Aluri, A., Price, B. S., \& McIntyre, N. H. (2019). Using machine learning to cocreate value through dynamic customer engagement in a brand loyalty program. Journal of Hospitality \& Tourism Research, 43(1), 78-100.

An, J., Do, D. K. X., Ngo, L. V., \& Quan, T. H. M. (2019). Turning brand credibility into positive word-of-mouth: integrating the signaling and social identity perspectives. Journal of Brand Management, 26(2), 157-175.

Baccarella, C. V., Wagner, T. F., Kietzmann, J. H., \& McCarthy, I. P. (2018). Social media? it's serious! understanding the dark side of social media. European Management Journal, 36(4), 431-438. doi:10.1016/j.emj.2018.07.002

Bapna, S., Benner, M. J., \& Qiu, L. (2019). Nurturing Online Communities: An Empirical Investigation. Management Information Systems Quarterly, 43(2), 425-452.

Barnes, F., \& Higgins, D. M. (2020). Brand image, cultural association and marketing: 'New Zealand'butter and lamb exports to Britain, c. 1920-1938. Business History, 62(1), 70-97.

Bhandari, M., \& Rodgers, S. (2018). What does the brand say? Effects of brand feedback to negative eWOM on brand trust and purchase intentions. International Journal of Advertising, 37(1), 125-141.

Carlson, J., Wyllie, J., Rahman, M. M., \& Voola, R. (2019). Enhancing brand relationship performance through customer participation and 
value creation in social media brand communities. Journal of Retailing and Consumer Services, 50, 333-341.

Connelly, B. L., Certo, S. T., Ireland, R. D., \& Reutzel, C. R. (2011). Signaling theory: A review and assessment. Journal of management, 37(1), 39-67.

Crespo-Hervás, J., Alguacil, M., \& Núñez-Pomar, J. (2018). Gender comparison of the perception of brand image and purchasing preferences of users of a sports service. Journal of Physical Education and Sport, 18, 1276-1284.

Chang, C. H. (2019). Do green motives influence green product innovation? The mediating role of green value co-creation. Corporate Social Responsibility and Environmental Management, 26(2), 330-340.

Chen, Y. S., Huang, A. F., Wang, T. Y., \& Chen, Y. R. (2020). Greenwash and green purchase behaviour: the mediation of green brand image and green brand loyalty. Total Quality Management \& Business Excellence, 31(1-2), 194-209.

Chu, S. C., Lien, C. H., \& Cao, Y. (2019). Electronic word-of-mouth (eWOM) on WeChat: Examining the influence of sense of belonging, need for self-enhancement, and consumer engagement on Chinese travellers' eWOM. International Journal of Advertising, 38(1), 26-49.

Danniswara, R., Sandhyaduhita, P., \& Munajat, Q. (2020). The impact of EWOM referral, celebrity endorsement, and information quality on 
purchase decision: A case of Instagram. In Global Branding: Breakthroughs in Research and Practice (pp. 882-905). IGI Global.

Das, S., \& Mishra, M. (2019). The Impact of Customer Relationship Management (CRM) Practices on Customer Satisfaction. In Business Governance and Society (pp. 43-54). Palgrave Macmillan, Cham.

Denizci Guillet, B., \& Shi, X. (2019). Can revenue management be integrated with customer relationship management? International Journal of Contemporary Hospitality Management, 31(2), 978-997.

Duarte, P., e Silva, S. C., \& Ferreira, M. B. (2018). How convenient is it? Delivering online shopping convenience to enhance customer satisfaction and encourage e-WOM. Journal of Retailing and Consumer Services, 44, 161-169.

Dwivedi, A., Johnson, L. W., Wilkie, D. C., \& De Araujo-Gil, L. (2019). Consumer emotional brand attachment with social media brands and social media brand equity. European Journal of Marketing, 53(6), 1176-1204.

Dwivedi, A., Nayeem, T., \& Murshed, F. (2018). Brand experience and consumers' willingness-to-pay (WTP) a price premium: Mediating role of brand credibility and perceived uniqueness. Journal of Retailing and Consumer Services, 44, 100-107.

Ekinci, Y., Sirakaya-Turk, E., \& Preciado, S. (2013). Symbolic consumption of tourism destination brands. Journal of Business Research, 66(6), 711-718. 
Erciş, A., Ünal, S., Candan, F. B., \& Yıldırım, H. (2012). The effect of brand satisfaction, trust and brand commitment on loyalty and repurchase intentions. Procedia-Social and Behavioral Sciences, $58,1395-1404$.

Eriksson, E. M. (2019). Representative co-production: broadening the scope of the public service logic. Public Management Review, 21(2), 291-314.

Errajaa, K., Daucé, B., \& Legoherel, P. (2020). Consumer reactions to olfactory congruence with brand image. Journal of Retailing and Consumer Services, 52, 101898.

Escalas, J. E., \& Bettman, J. R. (2003). You are what they eat: The influence of reference groups on consumers' connections to brands. Journal of consumer psychology, 13(3), 339-348.

Escamilla-Fajardo, P., Núñez-Pomar, J. M., Prado-Gascó, V. J., \& Ratten, V. (2020). HRM versus QCA: what affects the organizational climate in sports organizations?. Sport in Society, 23(2), 264-279.

Essamri, A., McKechnie, S., \& Winklhofer, H. (2019). Co-creating corporate brand identity with online brand communities: A managerial perspective. Journal of Business Research, 96, 366-375.

Favier, M., Celhay, F., \& Pantin-Sohier, G. (2019). Is less more or a bore? Package design simplicity and brand perception: an application to Champagne. Journal of Retailing and Consumer Services, 46, 1120. 
Ferrell, O. C., Harrison, D. E., Ferrell, L., \& Hair, J. F. (2019). Business ethics, corporate social responsibility, and brand attitudes: An exploratory study. Journal of Business Research, 95, 491-501.

Foroudi, P. (2019). Influence of brand signature, brand awareness, brand attitude, brand reputation on hotel industry's brand performance. International journal of hospitality management, 76, 271-285.

Frasquet, M., Mollá-Descals, A., \& Ruiz-Molina, M. E. (2017). Understanding loyalty in multichannel retailing: the role of brand trust and brand attachment. International Journal of Retail \& Distribution Management, 45(6), 608-625

Gálvez-Ruiz, P., Conde-Pascual, E., Estrella-Andrade, A., GarcíaFernández, J., Romero-Galisteo, R. P., Vélez-Colón, L., \& Pitts, B. G. (2018). Testing factorial invariance of the questionnaire of evaluation of the quality perceived in sports services in Spanish, Ecuadorian and Colombian users. Current Psychology, 1-8.

García-Fernández, J., Gálvez-Ruíz, P., Fernández-Gavira, J., Vélez-Colón, L., Pitts, B., \& Bernal-García, A. (2018). The effects of service convenience and perceived quality on perceived value, satisfaction and loyalty in low-cost fitness centers. Sport Management Review, 21(3), 250-262.

Gaustad, T., Samuelsen, B. M., Warlop, L., \& Fitzsimons, G. J. (2019). Too much of a good thing? Consumer response to strategic changes in brand image. International Journal of Research in Marketing, 36, 264-280. 
Greyser, S. A., \& Urde, M. (2019). What Does Your Corporate Brand Stand For?. Harvard Business Review, (1), 82-89.

Hafiz, K. A., \& Ali, K. A. M. (2018). brand image vs ceo's image: which matters to the consumers?. International Journal of Organization \& Business Excellence, 3(2), 1-14.

Halford, J. T., \& Hsu, S. H. (2014). Beauty is wealth: CEO appearance and shareholder value. Available at SSRN 2357756

Hong, S., \& Pittman, M. (2020). eWOM anatomy of online product reviews: interaction effects of review number, valence, and star ratings on perceived credibility. International Journal of Advertising, 1-29. https://doi.org/10.1080/02650487.2019.1703386

Hovland, C. I., Janis, I. L., \& Kelley, H. H. (1953). Communication and persuasion. Yale University Press.

Hu, F., \& Trivedi, R. H. (2020). Mapping hotel brand positioning and competitive landscapes by text-mining user-generated content. International Journal of Hospitality Management, 84, 102317.

Huber, F., Vollhardt, K., Matthes, I., \& Vogel, J. (2010). Brand misconduct: Consequences on consumer-brand relationships. Journal of Business Research, 63(11), 1113-1120.

Hussain, S., Melewar, T. C., Priporas, C. V., Foroudi, P., \& Dennis, C. (2020). Examining the effects of celebrity trust on advertising credibility, brand credibility and corporate credibility. Journal of Business Research, 109, 472-488. 
Iglesias, O., Markovic, S., Singh, J. J., \& Sierra, V. (2019). Do customer perceptions of corporate services brand ethicality improve brand equity? Considering the roles of brand heritage, brand image, and recognition benefits. Journal of Business Ethics, 154(2), 441-459.

Itani, O. S., Kassar, A. N., \& Loureiro, S. M. C. (2019). Value get, value give: The relationships among perceived value, relationship quality, customer engagement, and value consciousness. International Journal of Hospitality Management, 80, 78-90.

Japutra, A., Ekinci, Y., \& Simkin, L. (2019). Self-congruence, brand attachment and compulsive buying. Journal of Business Research, 99, 456-463.

Jeng, S. P. (2016). The influences of airline brand credibility on consumer purchase intentions. Journal of Air Transport Management, 55, 18.

Jeon, M. M., \& Jeong, M. (2017). Customers' perceived website service quality and its effects on e-loyalty. International Journal of Contemporary Hospitality Management, 29(1), 438-457

Jin, C., Yoon, M., \& Lee, J. (2019). The influence of brand colour identity on brand association and loyalty. Journal of Product \& Brand Management, 28(1), 50-62.

Johnson, Z. S., Mao, H., Lefebvre, S., \& Ganesh, J. (2019). Good Guys Can Finish First: How Brand Reputation Affects Extension Evaluations. Journal of Consumer Psychology, 29(4), 565-583. 
Jones, C. W., Byon, K. K., \& Huang, H. (2019). Service Quality, Perceived Value, and Fan Engagement: Case of Shanghai Formula One Racing. Sport Marketing Quarterly, 28(2), 63-76.

Kaur, H., Paruthi, M., Islam, J., \& Hollebeek, L. D. (2020). The role of brand community identification and reward on consumer brand engagement and brand loyalty in virtual brand communities. Telematics and Informatics, 46, 1-12.

Khan, I., \& Fatma, M. (2019). Connecting the dots between CSR and brand loyalty: the mediating role of brand experience and brand trust. International Journal of Business Excellence, 17(4), 439-455.

Kim, E. J., Kim, S. H., \& Lee, Y. K. (2019). The effects of brand hearsay on brand trust and brand attitudes. Journal of Hospitality Marketing \& Management, 28(7), 1-20.

Kim, M. S., Shin, D. J., \& Koo, D. W. (2018). The influence of perceived service fairness on brand trust, brand experience and brand citizenship behavior. International Journal of Contemporary Hospitality Management, 30(7), 2603-2621.

Kolyperas, D., Maglaras, G., \& Sparks, L. (2019). Sport fans' roles in value co-creation. European Sport Management Quarterly, 19(2), 201220.

Kumar, J., \& Nayak, J. K. (2019). Understanding the participation of passive members in online brand communities through the lens of psychological ownership theory. Electronic Commerce Research 
and Applications, $\quad 11(2), \quad 101-116$

https://doi.org/10.1016/j.elerap.2019.100859

Liu, H., Jayawardhena, C., Dibb, S., \& Ranaweera, C. (2019). Examining the trade-off between compensation and promptness in eWOMtriggered service recovery: A restorative justice perspective. Tourism Management, 75, 381-392.

Lobschat, L., Zinnbauer, M. A., Pallas, F., \& Joachimsthaler, E. (2013). Why social currency becomes a key driver of a firm's brand equityInsights from the automotive industry. Long Range Planning, 46(12), 125-148.

López-Carril, S., Villamón, M., \& Sanz, V. A. (2019). Conceptualización de los medios sociales: oportunidades para la gestión del deporte (Conceptualization of Social Media: opportunities for Sport Management). Retos: nuevas tendencias en educación física, deporte y recreación, (36), 468-473

Loureiro, S. M. C., Sarmento, E. M., \& Le Bellego, G. (2017). The effect of corporate brand reputation on brand attachment and brand loyalty: Automobile sector. Cogent Business \& Management, 4(1), 1-12. https://doi.org/10.1080/23311975.2017.1360031

Marbach, J., Lages, C., Nunan, D., \& Ekinci, Y. (2019). Consumer engagement in online brand communities: the moderating role of personal values. European Journal of Marketing, 53(9), 1671-1700.

Markovic, S., Iglesias, O., Singh, J. J., \& Sierra, V. (2018). How does the perceived ethicality of corporate services brands influence loyalty 
and positive word-of-mouth? Analyzing the roles of empathy, affective commitment, and perceived quality. Journal of Business Ethics, 148(4), 721-740.

Mauri, A. G., \& Minazzi, R. (2013). Web reviews influence on expectations and purchasing intentions of hotel potential customers. International Journal of Hospitality Management, 34, 99-107. https://doi.org/10.1016/j.ijhm.2013.02.012

Muskat, B., Hörtnagl, T., Prayag, G., \& Wagner, S. (2019). Perceived quality, authenticity, and price in tourists' dining experiences: Testing competing models of satisfaction and behavioral intentions. Journal of Vacation Marketing, 25(4), 480-498.

Muskat, B., Hörtnagl, T., Prayag, G., \& Wagner, S. (2019). Perceived quality, authenticity, and price in tourists' dining experiences: Testing competing models of satisfaction and behavioral intentions. Journal of Vacation Marketing, 25(4), 480-498.

Na, S., Kunkel, T., \& Doyle, J. (2020). Exploring athlete brand image development on social media: the role of signalling through source credibility. European Sport Management Quarterly, 20(1), 88-108.

Njoroge, C., \& Obonyo, L. (2017). Influence of PR strategies on the success of ceo's image in selected organizations in Kenya. International Journal of Communication and Public Relation, 2(1), 46-66. 
Osborne, S. P., Radnor, Z., \& Strokosch, K. (2016). Co-production and the co-creation of value in public services: a suitable case for treatment?. Public Management Review, 18(5), 639-653.

Pandey, N., Tripathi, A., Jain, D., \& Roy, S. (2019). Does price tolerance depend upon the type of product in e-retailing? Role of customer satisfaction, trust, loyalty, and perceived value. Journal of Strategic Marketing, 1-20. doi: 10.1080/0965254x.2019.1569109

Parikh, A. A., Behnke, C., Nelson, D., Vorvoreanu, M., \& Almanza, B. (2015). A qualitative assessment of Yelp. Com users' motivations to submit and read restaurant reviews. Journal of culinary science \& technology, 13(1), 1-18.

Plewa, C., Conduit, J., Quester, P. G., \& Johnson, C. (2015). The impact of corporate volunteering on CSR image: A consumer perspective. Journal of Business Ethics, 127(3), 643-659.

Purani, K., Kumar, D. S., \& Sahadev, S. (2019). e-Loyalty among millennials: Personal characteristics and social influences. Journal of Retailing and Consumer Services, 48, 215-223.

Quan, N., Chi, N., Nhung, D., Ngan, N., \& Phong, L. (2020). The influence of website brand equity, e-brand experience on e-loyalty: The mediating role of e-satisfaction. Management Science Letters, 10(1), 63-76.

Re, D. E., \& Rule, N. O. (2016). Making a (False) Impression: The Role of Business Experience in First Impressions of CEO Leadership Ability. Journal of Nonverbal Behavior, 40(3), 235-245. 
Samudro, A., Sumarwan, U., Simanjuntak, M., \& Yusuf, E. (2020). Assessing the effects of perceived quality and perceived value on customer satisfaction. Management Science Letters, 10(5), 10771084.

Sirgy, M. J., \& Su, C. (2000). Destination image, self-congruity, and travel behavior: Toward an integrative model. Journal of Travel Research, 38(4), 340-352.

Skoumpopoulou, D., \& Franklin, B. (2019). Implementing a Customer Relationship Management (CRM) System. In Advanced Methodologies and Technologies in Digital Marketing and Entrepreneurship (pp. 57-69). IGI Global.

Sota, S., Chaudhry, H., \& Srivastava, M. K. (2020). Customer relationship management research in hospitality industry: a review and classification. Journal of Hospitality Marketing \& Management, 29(1), 39-64.

Spence, M. (1973). Job market signaling. The Quarterly Journal of Economics, 87(3), 355-374

Tajfel, H., Turner, J. C., Austin, W. G., \& Worchel, S. (1979). An integrative theory of intergroup conflict. Organizational identity: A reader, 56-65.

Tellis, G. J., MacInnis, D. J., Tirunillai, S., \& Zhang, Y. (2019). What drives virality (Sharing) of online digital content? The critical role of information, emotion, and brand prominence. Journal of Marketing, 83(4), 1-20. 
Torfing, J., Sørensen, E., \& Røiseland, A. (2019). Transforming the public sector into an arena for co-creation: Barriers, drivers, benefits, and ways forward. Administration \& Society, 51(5), 795-825.

Wang, E. S. T. (2019). Effects of Brand Awareness and Social Norms on User-Perceived Cyber Privacy Risk. International Journal of Electronic Commerce, 23(2), 272-293.

Xie, C., Bagozzi, R. P., \& Grønhaug, K. (2019). The impact of corporate social responsibility on consumer brand advocacy: The role of moral emotions, attitudes, and individual differences. Journal of Business Research, 95, 514-530.

Yang, Z., Sun, S., Lalwani, A. K., \& Janakiraman, N. (2019). How Does Consumers' Local or Global Identity Influence Price-Perceived Quality Associations? The Role of Perceived Quality Variance. Journal of Marketing, 83(3), 145-162.

Yen, C. L. A., \& Tang, C. H. H. (2019). The effects of hotel attribute performance on electronic word-of-mouth (eWOM) behaviors. International Journal of Hospitality Management, 76, 9-18.

Za, S., Pallud, J., Agrifoglio, R., \& Metallo, C. (2020). Value Co-creation in Online Communities: A Preliminary Literature Analysis. In Exploring Digital Ecosystems (pp. 33-46). Springer, Cham.

Zablocki, A., Schlegelmilch, B., \& Houston, M. J. (2019). How valence, volume and variance of online reviews influence brand attitudes. Academy of Marketing Science Review, 9(1-2), 61-77. 


\subsection{Referencias Estudio 1. The importance of the services brand in predicting loyalty and word of mouth}

Ameri, H.S., \& Behnam, M. (2014). The effect of brand credibility on consumers' perception about brands and their purchasing behaviors in sport goods. Sport Science, 7(2), 50-57.

Asada, A., \& Ko, Y. J. (2016). Determinants of word-of-mouth influence in sport viewership. Journal of Sport Management, 30(2), 192-206.

Bentler, P.M. (2001). EQS 6 structural equations program manual. Encino, CA: Multivariate Software.

Besharat, A. (2010). How co-branding versus brand extensions drive consumers' evaluations of new products: A brand equity approach. Industrial Marketing Management, 39(8), 1240-1249.

Bougoure, U. S., Russell-Bennett, R., Fazal-E-Hasan, S., \& Mortimer, G. (2016). The impact of service failure on brand credibility. Journal of Retailing and Consumer Services, 31, 62-71.

Boulding, W., Kalra, A., Staelin, R., \& Zeithaml, V.A. (1993). A dynamic process model of service quality: from expectations to behavioral intentions. Journal of Marketing Research, 30(1), 7-27.

Brexendorf, T. O., \& Keller, K. L. (2017). Leveraging the corporate brand: the importance of corporate brand innovativeness and brand architecture. European Journal of Marketing, 51(9/10), 1530-1551. 
Browne, M.W., \& Cudeck, R. (1993). Alternative ways of assessing model fit, in Bollen, K. A., Long, J. S. (eds.), Testing structural equation model. Newbury Park, CA, Sage, 136-162.

Burmann, C., Schaefer, K., \& Maloney, P. (2008). Industry image: Its impact on the brand image of potential employees. Journal of Brand Management, 16(3), 159-176.

Calabuig, F., Crespo-Hervás, J., Prado-Gascó, V., Mundina, J., Valantine, I., \& Stanislovaitis, A. (2016). Quality of sporting events: validation of the eventqual scale. Transformation in Business \& Economics, 15(2), 21-32.

Carmen, R., \& Marius, S. (2016). Customer loyalty using customer relationship management. Management Strategies Journal, 31(1), 285-288.

Chang, Y.H., \& Yeh, C.H. (2002). A survey analysis of service quality for domestic airlines. European Journal of Operational Research, 139(1), 166-177.

Chaudhuri, A., \& Holbrook, M. B. (2001). The chain of effects from brand trust and brand affect to brand performance: the role of brand loyalty. Journal of Marketing, 65(2), 81-93.

Crespo, J., Pérez-Campos, C., \& Mundina, J. (2012). Calidad de servicio percibida por los espectadores de fútbol. Análisis de diferencias entre grupos [Spectators' perceived service quality of a football event. Analysing differences between groups]. Journal of Sports Economics \& Management, 2(1), 4-15. 
Dick, A. S., Basu, K. (1994). Customer loyalty: toward an integrated conceptual framework. Journal of the Academy of Marketing Science, 22(2), 99-113.

Dowling, G. (1986). Managing your Corporate Images. Industrial Marketing Management, 15(2), 109-115.

Eagly, A. H., Chaiken, S. (2007). The advantages of an inclusive definition of attitude. Social cognition, 25(5), 582-602.

East, R., Hammond, K., Lomax, W. (2008). Measuring the impact of positive and negative word of mouth on brand purchase probability. International Journal of Research in Marketing, 25(3), 215-224.

Erdem, T., Swait, J. (2004). Brand credibility and its role in brand choice and consideration. Journal of Consumer Research, 31(1), 191-199.

Erdem, T., Swait, J., Louviere, J. (2002). The impact of brand credibility on consumer price sensitivity. International Journal of Research in Marketing, 19(1), 1-19.

European Commission (2013). Study on the contribution of sport to economic growth and employment. Retrieved from: http://ec.europa.eu/assets/eac/sport/library/studies/studycontribution-spors-economic-growth-final-rpt.pdf

Evanschitzky, H., \& Wunderlich, M. (2006). An examination of moderator effects in the four-stage loyalty model. Journal of Service Research, 8(4), 330-345. 
Farr, A., \& Hollis, N. (1997). What do you want your brand to be when it grows up: big and strong? Journal of Advertising Research, 36(6), 23-36.

Fornell, C., \& Larcker, D. (1981). Evaluating structural equation models with unobservable variables and measurement error. Journal of Marketing Research, 18(1), 39-50.

Grönroos, C. (1984). A service quality model and its market implications. European Journal of Marketing, 18(4), 36-44.

Gwinner, K., \& Bennet, G. (2008). The impact of brand cohesiveness and sport identification on brand fit in a sponsorship context. Journal of Sport Management, 22(4), 410-426.

Hair, J. F., Black, W. C., Babin, B. J., Anderson, R. E., \& Tatham, R. L. (2006). Multivariate data analysis (6th ed.), Upper Saddle River, NJ, Pearson Prentice Hall.

Hightower, R., Brady, M. K., \& Baker, T. L. (2002). Investigating the role of the physical environment in hedonic service consumption: an exploratory study of sporting events. Journal of Business Research, 55(9), 697-707.

Hu, L. T., \& Bentler, P. M. (1999). Cutoff criteria for fit indexes in covariance structure analysis: Conventional criteria versus new alternatives. Structural Equation Modelling: A Multidisciplinary Journal, 6(1), 1-55. 
Jeng, S. P. (2016). The influences of airline brand credibility on consumer purchase intentions. Journal of Air Transport Management, 55, 18.

John, J. (2011). An analysis on the customer loyalty in telecom sector. Special reference to Bharath Sanchar Nigam limited, India. African Journal of Marketing Management, 3(1), 1-5.

Keng, C. J., Chang, W. H., Chen, C. H., \& Chang, Y. Y. (2016). Mere virtual presence with product experience affects brand attitude and purchase intention. Social Behavior and Personality, 44(3), 431.

Kim, S. H., Kim, M., \& Holland, S. (2017). How customer personality traits influence brand loyalty in the coffee shop industry: the moderating role of business types. International Journal of Hospitality \& Tourism Administration, 1-25.

Kline, R. B. (1998). Principles and practice of structural equation modelling. New York, NY: The Guilford Press.

Ko, Y. J., \& Kim, Y. K. (2014). Determinants of consumers' attitudes toward a sport sponsorship: a tale from college athletics. Journal of Nonprofit \& Public Sector Marketing, 26(3), 185-207.

Kumar, V., \& Shah, D. (2004). Building and sustaining profitable customer loyalty for the 21st Century. Journal of Retailing, 80(4), 317-330.

Kunkel, T., Doyle, J. P., Funk, D. C., Du, J., \& McDonald, H. (2016). The development and change of brand associations and their influence 
on team loyalty over time. Journal of Sport Management, 30(2), 117-134.

Li, Y., Wan, X., \& Yang, Z. (2011). The effects of corporate-brand credibility, perceived corporate-brand origin, and self-image congruence on purchase intention: evidence from China's auto industry. Journal of Global Marketing, 24(1), 58-68.

Low, G., \& Lamb, C. (2000). The measurement and dimensionality of brand associations. Journal of Product \& Brand Management, 9(6), 350-368.

Mikkelsen, M., Van Durme, J., \& Carrie, D.G. (2003). Viewers talking about television advertising: a supplementary measure of advertising effectiveness. Paper presented at the 32nd EMAC, Glasgow, 20-23rd May.

Moeller, S. (2010). Characteristics of services-a new approach uncovers their value. Journal of Services Marketing, 24(5), 359-368.

Murray, D., \& Howat, G. (2002). The relationships among service quality, value, satisfaction, and future intentions of customers at an Australian sports and leisure centre. Sport Management Review, $5(1), 25-43$.

Nyadzayo, M. W., \& Khajehzadeh, S. (2016). The antecedents of customer loyalty: a moderated mediation model of customer relationship management quality and brand image. Journal of Retailing and Consumer Services, 30, 262-270. 
Oliver, R. L. (1999). Whence consumer loyalty? Journal of Marketing, 63, $33-44$.

O'Loughlin, D., \& Szmigin, I. (2006). Emerging perspectives on customer relationships, interactions and loyalty in Irish retail financial services. Journal of Consumer Behaviour, 5(2), 117-129.

Pappu, R., \& Quester, P. G. (2016). How does brand innovativeness affect brand loyalty? European Journal of Marketing, 50(1/2), 2-28.

Parasuraman, A., Zeithaml V. A., \& Berry L. L. (1988). Servqual: A multiple-item scale for measuring consumer perceptions of service quality. Journal of Retailing, 64(1), 12-40.

Parasuraman, A., Zeithaml, V.A., \& Berry, L.L. (1985). A conceptual model of service quality and its implications for future research. Journal of Marketing, 49(4), 41-50.

Piligrimiene, Z., Dovaliene, A., \& Virvilaite, R. (2015). Consumer engagement in value co-creation: what kind of value it creates for company? Inzinerine Ekonomika-Engineering Economics, 26(4), 452-460.

Ratten, V. (2018). System Processes in Sport Entrepreneurship. In: Sport Entrepreneurship. Management for Professionals. Springer, Cham.

Schumacker, R., \& Lomax, R., (2004). A beginner's guide to structural equation modeling ( $2^{\mathrm{a}}$ ed.), Mahwah, NJ: Lawrence Erlbaum Associates. 
Shah, S. S. H., Aziz, J., Jaffari, A. R., Waris, S., Ejaz, W., Fatima, M., \& Sherazi, S. K. (2012). The impact of brands on consumer purchase intentions. Asian Journal of Business Management, 4(2), 105-110.

Sharp, B. (1995). Brand equity and market-based assets of professional service firms. Journal of Professional Services Marketing, 13(1), 313.

Sobel, J. (1985). A theory of credibility. Review of Economic Studies, 52(4), 557-573.

Swait, J., \& Erdem, T. (2007). Brand effects on choice and choice set formation under uncertainty. Marketing Science, 26(5), 679-697.

Sweeney, J. C., \& Swait, S. (2008). The effects of brand credibility on customer loyalty. Journal of Retailing and Consumer Services, 15(3), 179-193.

Thwaites, D. (1999). Closing the gaps: service quality in sport tourism. Journal of Services Marketing, 13(6), 500-516.

Tong, X., \& Hawley, J. M. (2009). Measuring customer-based brand equity: empirical evidence from the sportswear market in China. Journal of Product \& Brand Management, 18(4), 262-271.

Van Esterik-Plasmeijer, P. W., \& Van Raaij, W. F. (2017). Banking system trust, bank trust, and bank loyalty. International Journal of Bank Marketing, 35(1), 97-111. 
Wakefield, K. L., \& Blodgett, J. (2016). Retrospective: The importance of servicescapes in leisure service settings. Journal of Services Marketing, 30(7), 686-691

Wang, Y. J., Hernandez, M. D., \& Minor, M. S. (2010). Web aesthetics effects on perceived online service quality and satisfaction in an etail environment: The moderating role of purchase task. Journal of Business Research, 63(9-10), 935-942.

White, L., \& Yanamandram, V. (2004). Why customers stay: reasons and consequences of inertia in financial services. Managing Service Quality: An International Journal, 14(2/3), 183-194.

Yolal, M., Chi, C. G. Q., \& Pesämaa, O. (2017). Examine destination loyalty of first-time and repeat visitors at all-inclusive resorts. International Journal of Contemporary Hospitality Management, 29(7), 1834-1853.

Yoo, B., \& Donthu, N. (2001). Developing and validating a multidimensional consumer-based brand equity scale. Journal of Business Research, 52(1), 1-14.

Zeithaml, V.A. (1988). Consumer perceptions of price, quality, and value a means-end model and Synthesis of evidence. Journal of Marketing, 52(3), 2-22. 



\subsection{Referencias Estudio 2. Perceived value, satisfaction and future intentions in sport services: putting congruence and brand trust in the equation. Linear models vs QCA}

Alonso Dos Santos, M., \& Calabuig, F. (2018). Assessing the effectiveness of sponsorship messaging: Measuring the impact of congruence through electroencephalogram. International Journal of Sports Marketing and Sponsorship, 19(1), 25-40.

Alonso Dos Santos, M., Calabuig, F., \& Sánchez-Franco, M. (2019). Congruence and placement in sponsorship: An eye-tracking application, Physiology \& Behavior, 200, 159-165.

Anderson, E. W., Fornell, C., \& Lehmann, D. R. (1994). Customer satisfaction, market share, and profitability: findings from Sweden, The Journal of Marketing, 58(2), 53-66.

Bajac, H., Palacios, M., \& Minton, E. A. (2018). Consumer-brand congruence and conspicuousness: an international comparison. International Marketing Review, 35(3), 498-517.

Barton, H., \& Beynon, M. J. (2015). Do the citizens of Europe trust their police?. International Journal of Emergency Services, 4(1), 65-85.

Bettencourt, L. A. (1997). Customer voluntary performance: customers as partners in service delivery. Journal of Retailing, 73(3), 383-406. 
Bougoure, U. S., Russell-Bennett, R., Fazal-E-Hasan, S., \& Mortimer, G. (2016). The impact of service failure on brand credibility. Journal of Retailing and Consumer Services, 31, 62-71.

Buil-Carrasco, I., \& Montaner-Gutiérrez, T. (2008). Factores clave en la formación de la actitud del consumidor hacia las extensiones de marca, Cuadernos de Estudios Empresariales, 18, 109-134.

Calabuig, F., Prado-Gascó, V., Crespo-Hervás, J., Núñez-Pomar, J., \& Añó, V. (2016). Predicting future intentions of basketball spectators using SEM and fsQCA. Journal of Business Research, 69(4), 13961400.

Chaudhuri, A., \& Holbrook, M. B. (2001). The chain of effects from brand trust and brand affect to brand performance: the role of brand loyalty, Journal of Marketing, 65(2), 81-93.

Chen, C. F., \& Chen, F. S. (2010). Experience quality, perceived value, satisfaction and behavioral intentions for heritage tourists, Tourism Management, 31(1), 29-35.

Chen, Z., \& Dubinsky, A. J. (2003). A conceptual model of perceived customer value in e-commerce: A preliminary investigation. Psychology \& Marketing, 20(4), 323-347.

Claude, R., \& Christopher, R. (2014), Acq [Computer Programme], Houston, TX: University of Houston-Downtown.

Cronin, J. J., Brady, M. K., Brand, R. R., Hightower Jr, R., \& Shemwell, D. J. (1997). A cross-sectional test of the effect and 
conceptualization of service value. Journal of services Marketing, 11(6), 375-391.

Delgado-Ballester, E., \& Luis Munuera-Alemán, J. (2001). Brand trust in the context of consumer loyalty. European Journal of marketing, $35(11 / 12), 1238-1258$.

Delgado-Ballester, E., Munuera-Aleman, J.L., \& Yagüe-Guillen, M.J. (2003). Development and validation of a brand trust scale, International Journal of Market Research, 45(1), 35-53.

Dwivedi, A., \& McDonald, R. (2018). Building brand authenticity in fastmoving consumer goods via consumer perceptions of brand marketing communications. European Journal of Marketing, 52(7/8), 1387-1411. doi:10.1108/ejm-11-2016-0665

Eng, S., \& Woodside, A. G. (2012). Configural analysis of the drinking man: Fuzzy-set qualitative comparative analyses. Addictive Behaviors, 37(4), 541-543.

Erciş, A., Ünal, S., Candan, F. B., \& Yıldırım, H. (2012). The effect of brand satisfaction, trust and brand commitment on loyalty and repurchase intentions. Procedia-Social and Behavioral Sciences, (58), 1395-1404.

Festinger, L. (1957), A Theory of Cognitive Dissonance, Stanford University Press: Stanford, California.

Fiss, P. C. (2011). Building Better Causal Theories: A Fuzzy Set Approach to Typologies in Organizational Research. Academy of 
8. Referencias Estudio 2

Management Journal, $\quad$ 54(2), 393-420.

https://doi.org/10.5465/AMJ.2011.60263120

Fornell, C. (1992). A national customer satisfaction barometer: The Swedish experience. The Journal of Marketing, 56(1), 6-21.

Fornell, C., \& Larcker, D. F. (1981). Structural equation models with unobservable variables and measurement error: Algebra and statistics. Journal of Marketing Research, 18(1), 39-50.

Frasquet, M., Mollá-Descals, A., \& Ruiz-Molina, M. E. (2017). Understanding loyalty in multichannel retailing: the role of brand trust and brand attachment, International Journal of Retail \& Distribution Management, 45(6), 608-625.

Ghantous, N. (2016). The Impact of Services Brand Personality on Consumer-Brand Relationship Quality. Services Marketing Quarterly, 37(3), 185-199.

Gil, I., Sánchez, M., Berenguer, G., \& González-Gallarda, M. (2006), Encuentro de servicio, valor percibido y satisfacción del cliente en la relación entre empresas, Cuadernos de Estudios Empresariales, 1(15), 47-72.

Giménez-Espert, M. del C., \& Prado-Gascó, V. J. (2018b). The role of empathy and emotional intelligence in nurses' communication attitudes using regression models and fuzzy-set qualitative comparative analysis models (fsQCA). Journal of Clinical Nursing, 27(13-14), 2661-2672. 
Grace, D., \& O'Cass, A. (2005). Service branding: consumer verdicts on service brands. Journal of Retailing and Consumer Services, 12(2), $125-139$.

Grönroos, C. (1984). A service quality model and its marketing implications. European Journal of Marketing, 18(4), 36-44.

Ha, H. Y., \& Perks, H. (2005). Effects of consumer perceptions of brand experience on the web: Brand familiarity, satisfaction and brand trust. Journal of Consumer Behaviour, 4(6), 438-452.

Hair, J. F., Black, W. C., Babin, B., Anderson, R. E., \& Tatham, R. L. (2006), Multivariate data analysis, (6th ed.) New Jersey: Prentice Hall.

Howat, G., \& Assaker, G. (2013). The hierarchical effects of perceived quality on perceived value, satisfaction, and loyalty: Empirical results from public, outdoor aquatic centres in Australia. Sport Management Review, 16(3), 268-284.

Hur, W. M., Kim, M., \& Kim, H. (2014). The role of Brand trust in male customers' relationship to luxury brands. Psychological Reports, 114(2), 609-624.

Jamal, A., \& Goode, M. M. (2001). Consumers and brands: a study of the impact of self-image congruence on brand preference and satisfaction. Marketing Intelligence \& Planning, 19(7), 482-492.

Jin, N., Lee, S., \& Lee, H. (2015). The effect of experience quality on perceived value, satisfaction, image and behavioral intention of 
water park patrons: New versus repeat visitors. International Journal of Tourism Research, 17(1), 82-95.

Karampela, M., Tregear, A., Ansell, J., \& Dunnett, S. (2018). When opposites attract? Exploring the existence of complementarity in self-brand congruence processes. Psychology \& Marketing, 35(8), $1-13$.

Kim, M. S., Shin, D. J., \& Koo, D. W. (2018). The influence of perceived service fairness on brand trust, brand experience and brand citizenship behaviour. International Journal of Contemporary Hospitality Management, 30(7), 2603-2621.

Kim, M., \& Walker, M. (2013). The influence of professional athlete philanthropy on donation intentions. European Sport Management Quarterly, 13(5), 579-601.

Kim, Y., \& Peterson, R. A. (2017). A Meta-analysis of Online Trust Relationships in E-commerce. Journal of Interactive Marketing, 38, 44-54.

Kline, R. B. (1998). Software review: Software programs for structural equation modeling: Amos, EQS, and LISREL. Journal of Psychoeducational Assessment, 16(4), 343-364.

Kwak, D.H., \& Kang, J. H. (2009). Symbolic purchase in sport: the roles of self-image congruence and perceived quality. Management Decision, 47(1), 85-99. 
Lee, G. C., \& Leh, F. C. Y. (2011). Dimensions of customer-based brand equity: a study on malaysian brands. Journal of Marketing Research and Case Studies, 2011(2011), 1-10. Doi: $10.5171 / 2011.821981$

Legewie, N. (2013). An Introduction to Applied Data Analysis with Qualitative Comparative Analysis (QCA). Forum: Qualitative Social Research, 14(3), 1-45.

Londoño, B., Prado, Y., \& Salazar, V. (2017). Service quality, perceived value, satisfaction and intention to pay: The case of theatrical services. Academia Revista Latinoamericana de Administración, 30(2), 269-286.

Mittal, V., \& Kamakura, W. A. (2001). Satisfaction, repurchase intent, and repurchase behavior: Investigating the moderating effect of customer characteristics. Journal of Marketing Research, 38(1), 131-142.

Murray, D., \& Howat, G. (2002). The relationships among service quality, value, satisfaction, and future intentions of customers at an Australian sports and leisure centre. Sport Management Review, $5(1), 25-43$.

Pauwels-Delassus, V., \& Descotes, R. M. (2013). Brand name change: can trust and loyalty be transferred?. Journal of Brand Management, 20(8), 656-669. 
Pedragosa, V., \& Correia, A. (2009). Expectations, satisfaction and loyalty in health and fitness clubs. International Journal of Sport Management and Marketing, 5(4), 450-464.

Pham, M., Valette-Florence, P., \& Vigneron, F. (2018). Luxury brand desirability and fashion equity: The joint moderating effect on consumers' commitment toward luxury brands. Psychology \& Marketing, 35(12), 902-912. doi:10.1002/mar.21143

Prado-Gascó, V. J., \& Calabuig-Moreno, F. (2016). Measuring service quality of sporting events: Lineal models vs QCA. Journal of Sports Economics \& Management, 6(3), 126-136.

Prado-Gascó, V., Calabuig Moreno, F., Añó Sanz, V., Núñez-Pomar, J., \& Crespo Hervás, J. (2017). To post or not to post: social media sharing and sporting event performance. Psychology \& Marketing, 34(11), 995-1003.

Ragin, C. C. (2008), Redesigning Social Inquiry: Fuzzy sets and beyond, Chicago: University of Chicago Press.

Rey-Martí, A., Ribeiro-Soriano, D., \& Palacios-Marqués, D. (2016). A bibliometric analysis of social entrepreneurship. Journal of Business Research, 69(5), 1651-1655. https://doi.org/10.1016/j.jbusres.2015.10.033

Russell-Bennett, R., McColl-Kennedy, J. R., \& Coote, L. V. (2007). Involvement, satisfaction, and brand loyalty in a small business services setting. Journal of Business Research, 60(12), 1253-1260. 
Sahin, A., Zehir, C., \& Kitapçi, H. (2011). The effects of brand experiences, trust and satisfaction on building brand loyalty: An empirical research on global brands. Procedia-Social and Behavioral Sciences, 24, 1288-1301.

Schneider, C., \& Wagemann, C. (2012). Set-Theoretic Methods for the Social Sciences A Guide to Qualitative Comparative Analysis, Cambridge University Press, Ed.

Sirgy, M.J. (1982). Self-concept in consumer behavior: a critical review. Journal of Consumer Research, 9(3), 287-300.

Su, L., Swanson, S. R., Chinchanachokchai, S., Hsu, M. K., \& Chen, X. (2016). Reputation and intentions: The role of satisfaction, identification, and commitment, Journal of Business Research, 69(9), 3261-3269.

Sweeney, J. C., Soutar, G. N., \& Johnson, L. W. (1999). The role of perceived risk in the quality-value relationship: a study in a retail environment. Journal of Retailing, 75(1), 77-105.

Villanueva, L., Montoya-Castilla, I., \& Prado-Gasco, V. (2017). The importance of trait emotional intelligence and feelings in the prediction of perceived and biological stress in adolescents: hierarchical regressions and fsQCA models. Stress, 20(4), 355-362. https://doi.org/10.1080/10253890.2017.1340451

Vis, B. (2012). The comparative advantages of fsQCA and regression analysis for moderately large-N analyses. Sociological Methods \& Research, 41(1), 168-198. 
Woodside, A. G. (2013). Moving beyond multiple regression analysis to algorithms: Calling for adoption of a paradigm shift from symmetric to asymmetric thinking in data analysis and crafting theory. Journal of Business Research, 66(4), 463-472. https://doi.org/10.1016/j.jbusres.2012.12.021

Wu, H. C., \& Li, T. (2017). A study of experiential quality, perceived value, heritage image, experiential satisfaction, and behavioral intentions for heritage tourists. Journal of Hospitality \& Tourism Research, 41(8), 904-944.

Yang, Z., \& Peterson, R. T. (2004). Customer perceived value, satisfaction, and loyalty: The role of switching costs. Psychology \& Marketing, 21(10), 799-822.

Yoo, B., \& Donthu, N. (2001). Developing a scale to measure the perceived quality of an Internet shopping site (SITEQUAL). Quarterly Journal of Electronic Commerce, 2(1), 31-45.

Zeithaml, V. A. (1988). Consumer perceptions of price, quality, and value: a means-end model and synthesis of evidence. The Journal of marketing, 52(3), 2-22. 


\subsection{Referencias Estudio 3. Be congruent and I will be loyal: the case of sport services.}

Alguacil, M., M. A. Dos Santos, A. Pastor-Barceló, \& O. Colino. (2016). Comparative Qualitative Analysis of Loyalty in Public Sport Services. Revista de Psicología del Deporte, 25(1), 69-72.

Alonso-Dos-Santos, M., Vveinhardt, J., Calabuig, F., \& Montoro-Ríos, F. (2016). Involvement and image transfer in sports sponsorship. Engineering Economics, 27(1), 78-89.

Andreassen, T. W., \& Lindestad, B. (1998). Customer Loyalty and Complex Services: The impact of corporate image on quality, customer satisfaction and loyalty for customers with varying degrees of service expertise. International Journal of Service Industry Management 9(1), 7-23.

Aurier, P., \& N'Goala, G. (2010). The differing and mediating roles of trust and relationship commitment in service relationship maintenance and development. Journal of the Academy of Marketing Science, 38(3), 303-325.

Bagozzi, R. P., \& Yi, Y. (1988). On the evaluation of structural equation models. Journal of the Academy of Marketing Science, 16(1), 7494. 
Bajac, H., Palacios, M., \& Minton, E. (2018). Consumer-brand congruence and conspicuousness: an international comparison. International Marketing Review, 35(3), 498-517.

Bentler, P.M. (2006). EQS 6 structural equations program manual, Encino, CA: multivariate software, Inc. ISBN 1-885898-03-7

Besharat, A. (2010). How co-branding versus Brand extensions drive consumers' evaluations of new products: a brand equity approach. Industrial Marketing Management, 39(8), 1240-1249.

Bloemer, J. M., \& Kasper, H. D. (1995). The complex relationship between consumer satisfaction and brand loyalty. Journal of Economic Psychology, 16(2), 311-329.

Bougoure, U. S., Russell-Bennett, R., Fazal-E-Hasan, S., \& Mortimer, G. (2016). The impact of service failure on brand credibility. Journal of Retailing and Consumer Services, 31, 62-71.

Browne, M.W., \& Cudeck, R. (1993). Alternative ways of assessing model fit. In Bollen, K. A., \& Long, J. S. (Eds.), Testing structural equation model (pp. 136-162), Newbury Park, CA: Sage.

Calabuig, F., Núñez-Pomar, J., Prado-Gascó, V., \& Añó, V. (2014). Effect of price increases on future intentions of sport consumers. Journal of business research, 67(5), 729-733.

Carnevale, M., Loureiro, Y.K., \& Kabadayi, S. (2018). Customer value creation for risky products: the role of brand trust and trusting beliefs. Journal of Creating Value, 4(1), 1-21. 
Chaudhuri, A., \& Holbrook, M. B. (2001). The chain of effects from brand trust and brand affect to brand performance: the role of brand loyalty. Journal of marketing, 65(2), 81-93.

Dall'Olmo Riley, F., \& De Chernatony, L. (2000). The service brand as relationships builder. British Journal of Management, 11(2), 137150.

Dawar, N., \& Pillutla, M. M. (2000). Impact of product-harm crises on brand equity: The moderating role of consumer expectations. Journal of marketing research, 37(2), 215-226.

Delgado-Ballester, E., \& Munuera-Alemán, J. (2005). Does brand trust matter to brand equity?. Journal of product \& brand management, 14(3), 187-196.

Delgado-Ballester, E., Munuera-Alemán, J.L., \& Yagüe-Guillen, M.J. (2003). Development and validation of a brand trust scale. International Journal of Market Research, 45(1), 35-53.

Dönmez, Y., \& Türkmen, F. (2018). The relation between the landscape design and brand image in purchase preferences of tourists: the case of Safranbolu and Nevşehir, in Turkey. Applied Ecology and Environmental Research, 16(1), 629-643.

Dowling, G. (1986). Managing your corporate images. Industrial Marketing Management, 15(2), 109-115.

Eagly, A. H., \& Chaiken, S. (2007). The advantages of an inclusive definition of attitude. Social cognition, 25(5), 582-602. 
Erdem, T., \& Swait, J. (1998). Brand equity as a signaling phenomenon. Journal of consumer Psychology, 7(2), 131-157.

Erdem, T., Swait, J., \& Louviere, J. 2002. The impact of brand credibility on consumer price sensitivity. International Journal of Research in Marketing, 19(1), 1-19.

Festinger, L. 1957. A theory of cognitive dissonance, Stanford, CA: Stanford University Press.

Fornell, C., \& Larcker, D. (1981). Evaluating structural equation models with unobservable variables and measurement error. Journal of Marketing Research, 18(1), 39-50.

Grace, D., \& O'Cass, A. (2005). Service branding: consumer verdicts on service brands. Journal of Retailing and Consumer Services, 12(2), 125-139.

Gwinner, K., \& Bennet, G. (2008). The impact of brand cohesiveness and sport identification on brand fit in a sponsorship context. Journal of Sport Management, 22(4), 410-426.

Hair, J. F., Black, W. C., Babin, B., Anderson, R. E., \& Tatham, R. L. (2006). Multivariate data analysis, (6th ed.) New Jersey: Prentice Hall.

He, H., \& Li, Y. 2010. Key service drivers for high-tech service brand equity: The mediating role of overall service quality and perceived value. Journal of Marketing Management, 27(1-2), 77-99. 
Herbig, P., \& Milewicz, J. (1995). The Relationship of Reputation and Credibility to Brand Success. Journal of Consumer Marketing, 12(4), 5-10.

Hu, L. T., \& Bentler, P. M. (1999). Cutoff criteria for fit indexes in covariance structure analysis: Conventional criteria versus new alternatives. Structural equation modeling: a multidisciplinary journal, 6(1), 1-55.

Hur, W. M., Kim, M., \& Kim, H. (2014). The role of Brand trust in male customers' relationship to luxury brands. Psychological Reports, $114(2), 609-624$.

Hussain, R., Al Nasser, A., \& Hussain, Y. K. (2015). Service quality and customer satisfaction of a UAE-based airline: An empirical investigation. Journal of Air Transport Management, 42, 167-175.

Kayaman, R., \& Arasli, H. (2007). Customer based brand equity: evidence from the hotel industry. Managing Service Quality: An International Journal, 17(1), 92-109.

Keng, C. J., Chang, W. H., Chen, C. H., \& Chang, Y. Y. (2016). Mere virtual presence with product experience affects brand attitude and purchase intention. Social Behavior and Personality: an international journal, 44(3), 431-444.

Kim, J., Morris, J. D., \& Swait, J. (2008). Antecedents of true brand loyalty. Journal of Advertising, 37(2), 99-117. 
Kline, R. B. (1998). Software review: Software programs for structural equation modeling: Amos, EQS, and LISREL. Journal of psychoeducational assessment, 16(4), 343-364.

Kressmann, F., Sirgy, M. J., Herrmann, A., Huber, F., Huber, S., \& Lee, D. J. (2006). Direct and indirect effects of self-image congruence on brand loyalty. Journal of Business Research, 59(9), 955-964.

Kwak, D.H., \& Kang, J. H. (2009). Symbolic purchase in sport: the roles of self-image congruence and perceived quality. Management Decision, 47(1), 85-99.

Leung, L. C., Bougoure, U. S., \& Miller, K. W. (2014). The effects of affective and utilitarian brand relationships on brand consideration. Journal of Brand Management, 21(6), 469-484.

Li, Y., Wang, X., \& Yang, Z. (2011). The effects of corporate-brand credibility, perceived corporate-brand origin, and self-image congruence on purchase intention: Evidence from China's auto industry. Journal of Global Marketing, 24(1), 58-68.

Mitchell, A. A., \& Olson, J. C. (1981). Are product attribute beliefs the only mediator of advertising effects on brand attitude?. Journal of Marketing Research, 18(3), 318-332.

Navarro-Bailón, M. Á. (2012). Strategic consistent messages in cross-tool campaigns: effects on brand image and brand attitude. Journal of Marketing Communications, 18(3), 189-202. 
O'Loughlin, D., \& Szmigin, I. (2006). Emerging perspectives on customer relationships, interactions and loyalty in Irish retail financial services. Journal of Consumer Behaviour, 5(2), 117-129.

Olson, E. L. (2010). Does sponsorship work in the same way in different sponsorship contexts?. European Journal of Marketing, 44(1-2), 180-199.

Park, C.W., MacInnis, D. J., Priester, J., Eisingerich, A. B., \& Iacobucci, D. (2010). Brand attachment and brand attitude strength: Conceptual and empirical differentiation of two critical brand equity drivers. Journal of marketing 74(6), 1-17.

Pauwels-Delassus, V., \& Descotes, R. M. (2013). Brand name change: Can trust and loyalty be transferred?. Journal of Brand Management, 20(8), 656-669.

Pitta, D. A., \& Katsanis, L.P. (1995). Understanding brand equity for successful brand extension. Journal of consumer marketing, 12(4), 51-64.

Ratneshwar, S., \& Shocker, A. D. (1991). Substitution in use and the role of usage context in product category structures. Journal of Marketing Research, 28(3), 281-295.

Rifon, N. J., Choi, S. M., Trimble, C. S., \& Li, H. (2004). Congruence effects in sponsorship: The mediating role of sponsor credibility and consumer attributions of sponsor motive. Journal of Advertising, $33(1), 30-42$. 
Saavedra, J. L., Urdaneta, D., Pirela, J. L., \& Colmenares, O. (2008). Medición de la personalidad de marca en el mercado automotriz. Visión gerencial, 1(1), 183-196.

Sattar, S., Ali, I., \& Arshad, A. (2014). Customer loyalty toward Nokia Brand. Journal of Marketing and Consumer Research, 4, 22-28.

Seo, W.J., Green, B.C., Ko, Y.K., Lee, S., \& Schenewark, J. (2007). The effect of web cohesion, web commitment and attitude toward the website on intentions to use NFL teams' Websites. Sport management review 10(3), 231-252.

Sirgy, M. J. (1982). Self-concept in consumer behavior: A critical review. Journal of consumer research, 9(3), 287-300.

Spears, N., \& Singh, S. N. (2004). Measuring attitude toward the brand and purchase intentions. Journal of Current Issues \& Research in Advertising, 26(2), 53-66.

Suh, J. C., \& Youjae, Y. (2006). When brand attitudes affect the customer satisfaction-loyalty relation: the moderating role of product involvement. Journal of Consumer Psychology, 16(2), 145-155.

Sweeney, J. C., \& Swait, S. (2008). The effects of brand credibility on customer loyalty. Journal of retailing and consumer services, 15(3), 179-193.

Thomas, V. L., Yeh, M., \& Jewell, R. D. (2015). Enhancing valuation: the impact of self-congruence with a brand on the endowment effect. Journal of Behavioral and Experimental Economics, 58, 178-185. 
Tong, X., \& J.M. Hawley. (2009). Measuring customer-based brand equity: empirical evidence from the sportswear market in china. Journal of Product and Brand Management, 18 (4), 262-271. doi:10.1108/10610420910972783

Torlak, O., Ozkara, B. Y., Tiltay, M. A., Cengiz, H., \& Dulger, M. F. (2014). The effect of electronic word of mouth on brand image and purchase intention: An application concerning cell phone brands for youth consumers in Turkey. Journal of Marketing Development and Competitiveness, 8(2), 61-68.

Veasna, S., Wu, W., \& Huang, C. (2013). The impact of destination source credibility: the mediating effect of destination image. Tourism Management, 36, 511-526.

Vlachos, P. A., Tsamakos, A., Vrechopoulos, A. P., \& Avramidis, P. K. (2009). Corporate social responsibility: attributions, loyalty, and the mediating role of trust. Journal of the Academy of Marketing Science, 37(2), 170-180.

Wang, M. C. H. (2017). Investigating the different congruence effects on sports sponsor brand equity. International Journal of Sports Marketing and Sponsorship, 18(2): 196-211. doi:10.2501/jar-2017042

Wang, S.W., \& Scheinbaum, A.C. (2018). Enhancing brand credibility via celebrity endorsement: trustworthiness trumps attractiveness and expertise, 58(1), 16-32. 
Wang, S.W., Kao, G.H.Y., \& Ngamsiriudom, W. (2017). Consumers' attitude of endorser credibility, brand and intention with respect to celebrity endorsement of the airline sector. Journal of Air Transport Management, 60, 10-17.

Wu, C. C. (2011). The impact of hospital brand image on service quality, patient satisfaction and loyalty. African Journal of Business Management, 5(12), 4873-4882.

Wu, P. C., \& Wang, Y. C. (2011). The influences of electronic word-ofmouth message appeal and message source credibility on brand attitude. Asia Pacific Journal of Marketing and Logistics, 23(4), 448-472.

Yoo, B., \& Donthu, N. (2001). Developing a scale to measure the perceived quality of an Internet shopping site (SITEQUAL). Quarterly Journal of Electronic Commerce, 2(1), 31-45.

Yoo, C., \& MacInnis, D. (2005). The brand attitude formation process of emotional and informational ads. Journal of Business Research, 58(10), 1397-1406.

Zhang, Y. (2015). The impact of brand image on consumer behavior: a literature review. Open journal of business and management, 3(1), 58-62. 


\section{ANEXOS}

9.1. Anexo I. Código QR del archivo PDF del estudio 1

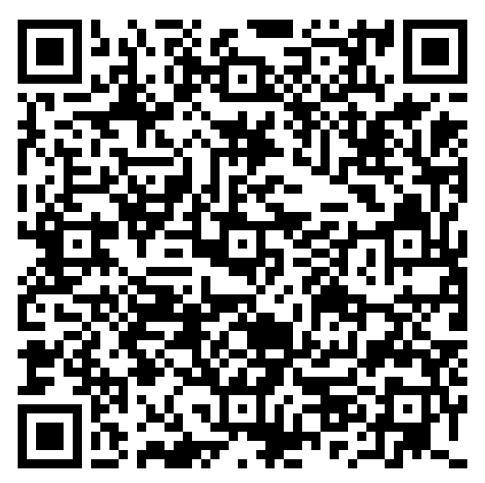



9.2. Anexo II. Código QR del archivo PDF del estudio 2

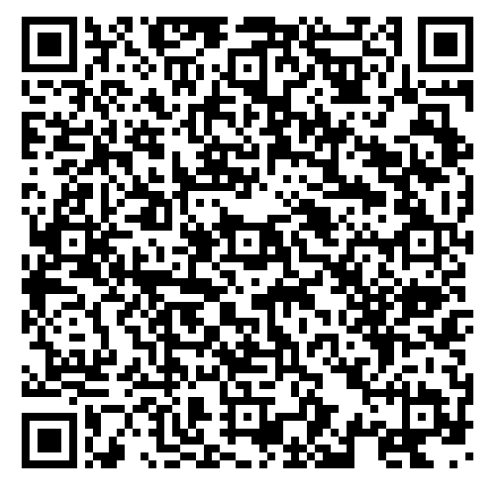



9.3. Anexo III. Código QR del archivo PDF del estudio 3

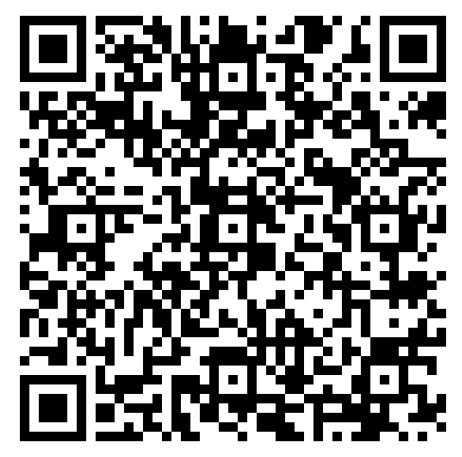

